Florida International University FIU Digital Commons

$11-10-2009$

\title{
From Stability to Insurgency: The Root and Proximate Causes of the September 2002 Civil War in Cote d'Ivoire
}

Bertin K. Kouadio

Florida International University, Miami, bkouadio100@gmail.com

DOI: $10.25148 /$ etd.FI09120810

Follow this and additional works at: https://digitalcommons.fiu.edu/etd

\section{Recommended Citation}

Kouadio, Bertin K., "From Stability to Insurgency: The Root and Proximate Causes of the September 2002 Civil War in Cote d'Ivoire" (2009). FIU Electronic Theses and Dissertations. 115.

https://digitalcommons.fiu.edu/etd/115 


\title{
FLORIDA INTERNATIONAL UNIVERSITY
}

Miami, Florida

FROM STABILITY TO INSURGENCY: THE ROOT AND PROXIMATE CAUSES OF THE SEPTEMBER 2002 CIVIL WAR IN CÔTE D'IVOIRE

\author{
A dissertation submitted in partial fulfillment of the \\ requirements for the degree of \\ DOCTOR OF PHILOSOPHY \\ in \\ INTERNATIONAL RELATIONS \\ by
}

Bertin K. Kouadio 
To: Dean Kenneth Furton

College of Arts and Sciences

This dissertation, written by Bertin Kouakou Kouadio, and entitled From Stability to Insurgency: The Root and Proximate Causes of the September 2002 Civil War in Côte d'Ivoire, having been approved in respect to style and intellectual content, is referred to you for judgment.

We have read this dissertation and recommend that it be approved.

Roderick Neumann

Mohiaddin Mesbahi

Jean M. Rahier

John F. Clark, Major Professor

Date of Defense: November 10, 2009

The dissertation of Bertin Kouakou Kouadio is approved.

$\begin{array}{r}\begin{array}{r}\text { Dean Kenneth Furton } \\ \text { College of Arts and Sciences }\end{array} \\ \hline \begin{array}{r}\text { Dean George Walker } \\ \text { University Graduate School }\end{array}\end{array}$

Florida International University, 2009 


\section{ACKNOWLEDGMENTS}

The completion of this dissertation marks the end of an exciting and difficult journey. I wish to thank my parents, Mr. Koffi Boussou, and Mr. Assida Koffi Ben in Côte d'Ivoire, for believing in me and supporting me throughout these long years. I am indebted to Professors Alma Gottlieb and Philip Graham of the University of Illinois at Urbana-Champaign, who sponsored me to come continue my education in the United States. I am grateful to the members of my committee for their mentorship, support, and patience. I also like to thank the West African Research Association, Florida/West Africa Linkage Institute, Ivoirian Embassy in Washington D.C., and American Taxpayers for their financial support. I wish to thank the Staff and Faculty of the International Relations department, College of Arts and Sciences, University Graduate School at FIU, and all my friends for their guidance and support. A TOUS MERCI INFINIMENT. 


\title{
ABSTRACT OF THE DISSERTATION \\ FROM STABILITY TO INSURGENCY: THE ROOT AND PROXIMATE CAUSES OF THE SEPTEMBER 2002 CIVIL WAR IN CÔTE D'IVOIRE
} by

\author{
Bertin K. Kouadio \\ Florida International University, 2009 \\ Miami, Florida \\ Professor John F. Clark, Major Professor
}

This dissertation was an analysis of the root and proximate causes of the September 2002 civil war in Côte d'Ivoire. The central question of this study was: Why did Côte d'Ivoire, which was relatively stable under President Houphouët-Boigny, suddenly begin to experience political violence in the 1990 s and an explosion in $2002 ?$ Côte d'Ivoire was an interesting case because it was stable for a long period of time, apparently making it an infertile ground for conflict. It was also interesting for comparative purposes because of the fact that several states in West Africa (for instance, Benin, Togo, and Ghana) have experienced military coups but not have civil wars. Finally, this case was an opportunity to revisit the debate on the causes of civil wars in the African context. Chapter one has outlined the entire dissertation project and contextualized the analysis that follows in the subsequent chapters. Chapter two has reviewed the literature on civil wars in general, identified the different types of civil wars, and the type the Ivoiran war is. Chapter three has examined the domestic and international political economy as a source of the civil violence in Côte d'Ivoire. Chapter 
four has examined the role of ethnicity and region as identities of the war, while chapter five has analyzed the role of the foreign relations in the civil war, as well as the regional political context. Chapter six has distinguished between the root and proximate causes of the Ivoirian civil war, made judgments about the relative weight of the various causes, and the extent to which the weight of the causes can be measured.

The study found that the "Ivoirite" was the most important trigger of the civil war in Côte d'Ivoire. The overall conclusion of my dissertation was that the September 2002 crisis in that country was a political crisis which occured in the context of a political reform. It first started with succession problems in 1993 followed by the controversial elections in 1995 and 2000. Later, this electoral politics spread beyond electoral issues, namely citizenship matters. 


\section{TABLE OF CONTENTS}

CHAPTER

PAGE

I. INTRODUCTION 1

The Long Period of Stability 5

Political Developments Immediately Proceeding 21

Overview of the Remaining Chapters 29

II. LITERATURE REVIEW 32

Identification of Different Types of Civil Wars $\quad 35$

Rebels Seeking Secession and Control of Resources $\quad 35$

State Dominance of Some Identity Group $\quad 39$

Rebels Seeking Redistribution of Wealth and Income 43

Wars against Colonizers 43

Discussion of the Type the Ivoirian Civil War Is 44

Debate Over the Causes of Civil Wars 49

Causes Related to Identity Group Difference $\quad 49$

States with a History of Inter-Identity Group Conflict 49

External Pressure for Democratization from the 1990s 51

Apperance of An Ethnic Group in Multi-Ethnic States 53

Causes Related to Social Deprivation, Class Conflict, Resource Scarcity $\quad 59$

Maldistribution of Wealth or Income Resulting to Social Deprivation 59

Rebels As People Without Other Social Prospects $\quad 61$

Sudden Redistribution of Wealth to the Upper Classes 63

$\begin{array}{ll}\text { Structural Adjustment Programs } & 64\end{array}$

Sudden Downturn in the Relative Value of State Commodities 68

Causes Related to Economic Gain for "Rebel-Entrepreneurs 70

$\begin{array}{ll}\text { Neo-Colonial Causes } & 72\end{array}$

III. DOMESTIC AND INTERNATIONAL POLITICAL ECONOMY 75

$\begin{array}{ll}\text { Background On the Ivoirian Economy } & 75\end{array}$

Period of Economic Growth (1060-1980) 81

Period of Economic Downfall (1981-1990) 85

$\begin{array}{ll}\text { Structural Adjustment Programs } & 86\end{array}$

Effects of Structural Adjustment Programs $\quad 93$

Coping With the Crisis and Effects of the Adjustments 98

Rebels'Attitude Toward the Local Resources 102

IV. $\quad$ ETHNICITY AND REGION AS IDENTITIES IN THE WAR 104

Unity Under Houphouet-Boigny (1960-1993) 105

Dis-unity in the Post-Houphouet-Boigny Era (1993-2002) 113

$\begin{array}{ll}\text { Composition of the Competing Military Forces } & 117\end{array}$

$\begin{array}{ll}\text { New Forces } & 117\end{array}$

$\begin{array}{ll}\text { National Forces of Côte d'Ivoire } & 125\end{array}$ 
V. ROLE OF FOREIGN RELATIONS IN THE WAR

Franco-African Relations: An Overview

Origins of Franco-Ivoirian Relations

Ivoirian Economic Crisis And French Aid

149

Ivoirian Political Crisis And French Aid

155

Côte d'Ivoire's Relations with Its Neighbors

VI. CONCLUSION

Distinction between the Root and Proximate Causes of the War

Judgment About the Relative Weight of the Various Causes

Relative Weight of the Root Causes

Relative Weight of the Proximate Causes

Measuring the Relative Weight of the Various Causes

Ivoirian Civil War in Comparative Perspective

Sierra Leone

Liberia

Non-Wars Under Political Reform 


\section{LIST OF TABLES}

TABLE

PAGE

1. Major Ethnic Groups 9

2. Major Languages 9

3. Major Religions 11

4. Human Development Index of Côte d'Ivoire (2002) 97

5. Major Leaders and Political Parties 114

6. Bilateral Aid Disbursements by France 152 


\section{LIST OF ACRONYMS}

\begin{tabular}{|c|c|}
\hline $\mathrm{ADO}$ & Allassane Dramane Ouattara \\
\hline BCEAO & Banque Centrale des Etats de l'Afrique de l'Ouest \\
\hline AERIA & Aéroport International Abidjan \\
\hline AJP & Alliance des Jeunes Patriotes \\
\hline APC & All People's Congress \\
\hline AU & African Union \\
\hline $\mathrm{BBC}$ & British Broadcast Corporation \\
\hline BICICI & Banque Ivoirienne de Commerce et Industrie de Côte d'Ivoire \\
\hline BNP & Banque Nationale de Paris \\
\hline CAISSTAB & Caisse de Stabilisation \\
\hline $\mathrm{CD}$ & Compact Disk \\
\hline CDEAO & Communaté des Etats de l'Afrique de l'Ouest \\
\hline CFA & Communaté Financière Africaine \\
\hline CFAO & Communauté Française de l'Afrique de l'Ouest \\
\hline CFCI & Compagnie Française de la Côte d'Ivoire \\
\hline CIDT & Compagnie Ivoirienne Des Textiles \\
\hline CIE & Comapgnie Ivoirienne d'Electricité \\
\hline CIPREL & Compagnie Ivoirienne de la Production d'Electricité \\
\hline $\mathrm{CNN}$ & Cable News Network \\
\hline COLAS & Société de Construction Routière \\
\hline DRC & Democratic Republic of Congo \\
\hline DVD & Digital Video Disc \\
\hline
\end{tabular}




\begin{tabular}{|c|c|}
\hline ECOMOG & Economic Community of West African States Monitoring Group \\
\hline ECOWAS & Economic Community of West African States \\
\hline EPLF & Eritrean People's Liberation Front \\
\hline EPRDF & Ethiopian People's Revolutionary Democratic Front \\
\hline ETA & Basques for Basques Homeland and Freedom \\
\hline EU & European Union \\
\hline FANCI & Force Armée Nationale de Côte d'Ivoire \\
\hline FESCI & Fédération Estudiantine et Scolaire de Côte d'Ivoire \\
\hline FF & French Franc \\
\hline FM & Fraternité Matin \\
\hline FN & Forces Nouvelles \\
\hline FPI & Front Populaire Ivoirien \\
\hline GDP & Gross Domestic Product \\
\hline GNP & Gross National Product \\
\hline GRIP & Group for Research of Information on Peace and Security \\
\hline GSDRC & Governance and Social Development Centre \\
\hline HDI & Human Development Index \\
\hline HIV/AIDS & Human Immunodeficiency Virus/Aquired Immunodeficieny Syndrome \\
\hline IB & Ibrahima Coulibaby \\
\hline ICG & International Crisis Group \\
\hline IFIs & International Financial Institutions \\
\hline IMF & International Monetary Fund \\
\hline INS & Institut National des Statistiques \\
\hline
\end{tabular}




\begin{tabular}{ll} 
MJP & Mouvement Pour la Justice et la Paix \\
MPCI & Mouvement Patrioque de Côte d'Ivoire \\
MPIGO & Mouvement Populaire des Ivoiriens du Grand Ouest \\
NBA & National Basketball Association \\
NFL & National Football Association \\
NPFL & National Patriotic Front of Liberia \\
OAU & Organization of African Unity \\
OCAM & Organisation Commune Africaine et Malgache \\
ONUCI & Opération des Nations Unies en Côte d'Ivoire \\
OXY & Occidental Petroleum Corporation \\
PDCI & Parti Démocratique de Côte d'Ivoire \\
PIB & Produit Intérieur Brut \\
PIT & Parti Ivoirien des Travailleurs \\
PKK & Kurdish Workers Party's Military Branch \\
PNB & Produit Nationale Brut \\
PSF & Parti Socialiste Français \\
RHDP & Rassemblement des Houphouëtistes Pour la Démocratie et la Paix \\
RDA & Rassemblement Démocratique Africain \\
RDR & Rassemblement Des Républicains \\
RFI & Radio France Interantionale \\
RPF & Rwandan Patriotic Front \\
RUF & Revoluationary United Front \\
SAA & Syndicat Agricole Africain \\
\hline
\end{tabular}




\begin{tabular}{ll} 
SACO & Société Africaine de Cocoa \\
SAPs & Structural Adjustment Programs \\
SCOA & Société Commerciale de l'Ouest Africain \\
SETAO & Société d'Etudes de Travaux Pour l'Afrique de L'Ouest \\
SGBCI & Société Générale de Banque en Côte d'Ivoire \\
SIB & Société Ivoirienne de Banque \\
SIR & Société Ivoirienne de Rafinage \\
SITARAIL & Société Internationale de Transport Africain Par Rail \\
SODECI & Société des Eaux de Côte d'Ivoire \\
SOGB & Société des Caoutchoucs de Grand-Béréby \\
SPLA & Sudan People's Liberation Army \\
UDPCI & Union Démocratique des Peuples de Côte d'Ivoire \\
UEMOA & Union Monétaire Ouest Africain \\
UGTCI & Union Générale des Travailleurs de Côte d'Ivoire \\
UN & United Nations \\
UNDP & United Nations Development Programmes \\
UNITA & National Union for the Total Independence of Angola \\
UNPEECI & Union Nationale des Parents d'Elèves et Etudiants de Côte d'Ivoire \\
USD & United States Dollar \\
\hline
\end{tabular}




\section{CHAPTER 1 \\ INTRODUCTION}

This dissertation is an analysis of the root and proximate causes of the September 2002 civil war in Côte d'Ivoire (also called Ivory Coast). It consists of six chapters and covers the period from 7 August 1960 (date of Côte d'Ivoire's independence from France) to 19 September 2002 (date of the beginning of the civil war). This study does not consider developments outside of this time period unless they are relevant in understanding the start of the Ivoirian civil war.

The chapter one outlines the entire dissertation project and contextualizes the analysis that is to follow. It is divided into three sections. The first section outlines the relatively long period of stability under President Houphouët-Boigny (1960-1993). The second section discusses the major events that led to the civil war after HouphouëtBoigny died in December 1993. The third section gives a brief overview of the remaining five chapters.

I should begin by stating that a countless number of interesting things may be said about civil wars, but this dissertation has a specific and narrow agenda. I am interested in understanding the root and proximate causes of the current civil war in Côte d'Ivoire. In other words, this dissertation seeks to understand how one of Africa's most stable and prosperous states has fallen victim to war. Since the civil war in Côte d'Ivoire was so unexpected, it should have something interesting to tell us about civil wars in general and African civil wars since the end of the Cold War in particular. 
Côte d'Ivoire is an interesting case because it was stable for a long period of time, apparently making it an infertile ground for conflict. Until 1990, this small West African state was dominated by a single-party system led by President Felix Houphouët-Boigny. A combination of internal and external factors forced the late president and the Democratic Party of Côte d'Ivoire (PDCI), to adopt multiparty democracy in 1990. Thereafter, the country experienced political tumult and then civil war. Côte d'Ivoire is also an interesting case for comparative purposes due the fact that several states in West Africa (for instance, Benin, Togo, and Ghana) have experienced military coups but not have civil wars. This begs the central question of this study: Why did Côte d'Ivoire, which was relatively stable under President Houphouët-Boigny, suddenly begin to experience political violence in the 1990s and an explosion in $2002 ?$

In order to answer this question I have organized this dissertation around the following contexts: First, I examined the domestic or national political context in which Côte d'Ivoire evolved since it became independent from France in 1960. Second, I discussed the regional context using Côte d'Ivoire's regional foreign policies towards its neighbors and other African states, identifying the major interactions (economic, political, and diplomatic) Côte d'Ivoire has had since its independence in 1960. Third, I explored the international context (namely the past and current relationships with France, as well as other non-African states, the world market, and the International Monetary Fund and World Bank), to measure which factors can be regarded as contributing factors to the crisis. The following five sub-questions and hypotheses were also developed in order to make a full assessment of how all the foregoing arguments measure up in the 
hope that their answers would ultimately reach an understanding why the civil war came to Côte d'Ivoire.

First, what kind of relationships existed between the former colonizing country (France) and Côte d'Ivoire before and after 1990? I begin by noting that France'support of Côte d'Ivoire was automatic under President Houphouët-Boigny, but this was not the case following the founding president's death. It should be noted that France and Côte d'Ivoire had signed multiple treaties (including political, diplomatic, economic, and military) during the early years of independence. Because of this France protected this country from both internal and external aggression. A change in this patron-client relationship may help explain the situation in Côte d'Ivoire.

Second, what kind of relationships existed between the various ethnic groups in Côte d'Ivoire under the single-party regime, and after the installation of multiparty democracy in 1990 ? That is, how was the unity of the country maintained under President Houphouët-Boigny? What changed after his death, and why? The study notes that under the first regime ethnic differences were managed, a model of ethnic tolerance was promoted using mass media, administrative, ideological, and promoting positive communication and interaction among members of different ethnic and, also religious groups. This was neglected in the subsequent regimes, including one military (19992000). Instead, a variety of influences promoted division and rivalry between ethnic and, especially religious groups. Such divisions initially began with electoral politics and then spread beyond electoral issues, namely the creation of the Ivoirité concept.

Third, to what extent were the neighboring states (Mali, Burkina Faso, and Liberia) guilty of collaborating with the rebellious friends or foes of the first regime? If 
so, and the interference was significant, what went wrong with these relationships? That is, why did they begin to intervene during the 1990s and 2000s when they have not done so before? The study hypothesizes that these neighboring states may have stimulated the rebellion for various reasons including cultural (origins, culture, and religion) or economic (migrant worker communities).

Fourth, what types of leadership quality or vision did the different leaders have for Côte d'Ivoire's economic and political development? The study hypothesizes that the new leaders who followed President Houphouët-Boigny may have lacked charisma or some other qualities of leadership that made them ineffective at holding the country together.

Fifth, what types of economic interactions did Côte d'Ivoire have then and now on the local, regional, and world market? What factors contributed to the economic decline or economic boom in this country? What happened to the price and local income from Côte d'Ivoire's cocoa and coffee? The study hypothesizes that changes in the world economy and Côte d'Ivoire's role in it may explain the change. Furthermore, the study questions whether the structural adjustment programs imposed by the International Monetary Fund (IMF) and World Bank in the 1980s and 1990s might have contributed to significant increase in poverty-for reasons now well-documented, including huge national debt, lack of money for infrastructure programs in education, health, and jobs, resulting in an increase in general misery of average and poor people resulting in higher general dissatisfaction or frustration.

My dissertation begins with the core assumption that the civil war in Côte d'Ivoire cannot be explained (that is, revealed to have one over-riding cause, or a network 
of intersecting causes whose influence can be quantified), but it can be understood (that is, one can identify the main contributing causes, and make some judgments about which are most influential, one can distinguish between necessary conditions, contributing conditions, and efficient usually posed as "proximate" causes. The overall conclusion will present all the arguments, weigh them and determine which causes seem particularly compelling and relevant to this case.

\section{The Long Period of Stability}

The period 1960-1980 was marked by significant economic progress that led analysts such as Amin (1970), Hecht (1983), and Nyong'oro (1978 and 1987), to describe Côte d'Ivoire as an exception in Sub-Saharan Africa. According to these scholars, Côte d'Ivoire, not only was regarded as the leading country in Francophone Africa, but also a symbol and model of political and economic success on the continent, and the developing world. Chabal (1993) and Rothchild et al. (1996) have also argued that President Houphouët-Boigny was the main architect of that relative success and stability. He was able to hold the various ethnic and religious communities together, while promoting economic prosperity. As a result, this country was attributed some flattering labels including: "oasis of prosperity and stability”, "economic miracle”, “ lung of West Africa", "heavy weight", “economic locomotive of West Africa", “African elephant”, or “success story” among others (Bakary 2003).

Côte d'Ivoire was a key player on the world stage both politically and economically under President Houphouët-Boigny. Nyong'oro (1978 and 1987), for example, writes that economically, he created an African capitalist model for his country that generated a huge success in the first two decades of independence, as well as massive 
West African immigrant communities into Côte d'Ivoire. A large number of people of Lebanese descent, French, and North Africans settled in Côte d'Ivoire also. Two hagiobiographies by Siriex (1975 and 1986) were dedicated to the Ivoirian leader. The first was Houphouët-Boigny: L'homme de la Paix (Houphouët-Boigny: The Man of Peace), and the second was Houphouët-Boigny ou la Sagesse Africaine (HouphouëtBoigny or The African Wisedom).

The late president was very active both inside and outside his country. At the continental level, Houphouët-Boigny played a major diplomatic role assisting in the resolution of many crises including: the Biafra war of 1967-1970 in Nigeria, the Angola and Mozambique wars of the 1970s and 1980s, the civil war in Liberia in the 1990s, and more. Furthermore, he granted asylum to many deposed ex-African leaders, and he remained the main leader of the famous La Françafrique (Franco-African Community) on the continent until his death in December 1993. Because of his political longevity and the respect he received by his peers, Houphouët-Boigny was considered the father, and source of wisdom and consultation for many young generations of African leaders including: Charles Taylor of Liberia, Thomas Sankara of Burkina Faso, Jerry Rwalings of Ghana, and Samora Machel of Mozambique, to mention just a few. Finally, he was personally involved in the dismantling of the Apartheid regime in South Africa. Unfortunately, he did not see other important developments after Nelson Mandela became president in that country.

Despite all of this, his legacy continues to divide Ivoirian communities. During my doctoral research in Abidjan in 2003 and 2004, I realized that any explanations of the past largely reflected party loyalty, personal experiences, and ethnic affiliations. Those 
who have benefited from his personal rule and the one-party state or belonged to his ethnic group were more sympathetic to him, when in reality his reign was also tarnished by unfortunate events which discussed in this dissertation also. In order to understand what is plaguing Côte d'Ivoire it is important to provide some background by highlighting the country's geography, ethnography, as well as history of settlement and spatial occupation.

Côte d'Ivoire has a total area of 322,460 square kilometers. It borders the Republics of Liberia and Guinea-Conakry (west), Mali (north-west), Burkina Faso (north), Ghana (east), and the Atlantic Ocean (south). It has two main vegetation belts that cut the country almost in half. The southern portion is covered by the tropical rainforest, and savanna in the north. Côte d'Ivoire enjoys a warm climate, tropical along the coast, semiarid in far north, three seasons-warm and dry (November to March), hot and dry (March to May), hot and wet (June to October). Though, the climate is now changing due to new local and global forces (Kouadio and Gottlieb 1997).

This country consists of five major ethnic groups (Mande, Kru, Akan, Gur, and the coastal people). The five ethnic groups consist of sixty-six dialects. The regional distribution of these ethnic groups is as follows: Akan speaking people (42\%), including the Baule, Anyi, and Abron, are largely located in the central region and along the eastern coast (and in neighboring countries, especially Ghana). The Mande people include two sub-groups: the northern Mande (17\%), consisting of the Dyula, Bamana, and Malinke, and southern Mande made up of the Wan, Beng, Mwan, Guro, Dan, Gban, and Tura, who account for $10 \%$. Originally from Liberia, Guinea, and Mali, most of them are located in the center-west region of the country. In the west are Kru speakers (11\%) consisting of 
the Guere, Wobe, Kodia, Grebo, Oubi, Neyo, Bakwe, Bete, and Niaboua, who came from Liberia, the Gambia, and Guinea. In the north (along the borders with Mali and Burkina Faso) is the Gur or Voltaic group (18\%), comprising primarily of the Senufo, Kulango, Lobi, and other small groups (Gouin, Site, Degha, Samogho, and Gonja). The coastal peoples consisting of Abe, Abidji, Abure, Mbato, Avikam, Nzima, Ebrie, Jackjack, Eotiole, Adjukru, and Alladian, are named for their location next to the coastal lagoon and the Atlantic Ocean. The 1998 data structure the main language groups of Côte d'Ivoire as follows: 23 percent Baule; 18 percent Bete; 15 percent Senufo; 11 percent Malinke; and 33 percent other (Kouadio and Gottlieb 1997, see also Konate 2004, Loucou 1984, and Kouadio 2007).

Also, there are significant numbers of immigrants from the Middleast and North Africa, Asia, and Europe. From other Sub-Saharan African countries these included primarily people from Nigeria, Burkina Faso, Benin, Togo, Senegal, Mali, Guinea, Ghana, Niger, and Liberia. Meanwhile, the civil wars in the Democratic Republic of the Congo, Liberia, Sierra Leone, famine in Ethiopia in the 1980s, and elsewhere on the continent caused immigration from these troubled countries into Côte d'Ivoire (Kouadio 2007). Table 1 and table 2 below respectively show the major ethnic groups and distribution, and languages within each group. Also, a linguistic map of Côte d'Ivoire is provided in Appendix A (p. 213). 
Table 1 : Major Ethnic Groups

\begin{tabular}{|l|c|c|}
\hline \multicolumn{1}{|c|}{ ETHNIC GROUP } & PERCENTAGE & LOCATION \\
\hline Akan & $42.1 \%$ & $\begin{array}{c}\text { Central Region and the } \\
\text { Eastern Coast }\end{array}$ \\
\hline Voltaic or Gur & $17.6 \%$ & North \\
\hline Northern Mande & $16.5 \%$ & Northwest \\
\hline Southern Mande & $10 \%$ & Southterwest \\
\hline Kru & $11 \%$ & Southern Atlantic Coast \\
\hline $\begin{array}{l}\text { Lagoon or Coastal } \\
\text { People }\end{array}$ & $2.8 \%$ & Across the country \\
\hline Other & 130,000 Lebanese 14,000 French +Other & \\
\hline
\end{tabular}

Source: Adapted from CIA Factbook (1998)-Côte d'Ivoire

Table 2: Major Languages

\begin{tabular}{|l|c|}
\hline \multicolumn{1}{|c|}{ ETHNIC GROUP } & LANGUAGE \\
\hline Akan & Baule, Anyi, and Abron \\
\hline Northern Mande & Dyula, Bambara, and Malinké \\
\hline Southern Mande & Wan, Beng, Mwan, Guro, Dan, Gban, and Tura \\
\hline Kru & $\begin{array}{c}\text { Guere, Wobe, Kodia, Grebo, Oubi, Neyo, Bakwe, Dida, Bete, } \\
\text { and Niaboua }\end{array}$ \\
\hline $\begin{array}{l}\text { Voltaic or Gur } \\
\text { Lagoon or Coastal } \\
\text { People }\end{array}$ & $\begin{array}{c}\text { Senufo, Kulango, Lobi, Gouin, Site, Degha, Samogho, Gonja } \\
\text { Ebotiole, Adjukru, and Alladian }\end{array}$ \\
\hline
\end{tabular}

Source: Bertin Kouadio and Alma Gottlieb (1997)

Côte d'Ivoire has three major religions including: practitioners of traditional

African religions or animism (25-40 percent), Muslim (35-40 percent), and Christian (20-

30 percent). The majority of foreigners (migrant workers from the Sahel region) are

Muslim (70\%), and Christian (20\%). These figures, however, are approximations, as 
there is much syncretism in religious practice, and mutual tolerance that seems to be fading away due to the recent political developments in the country since December 1993.

In fact, animist groups are fairly heterogeneous with assorted ancestors, gods, and spirits of the earth, forest, and sky being identified, sometimes alongside a high god. As for the major world religions, many Ivoirians add the Christian or Muslim god and associated religious practices to their old customs and pantheons, rather than converting fully. But, religious differences had never been a source of conflict in Côte d'Ivoire before. Committed converts to Christianity or Islam tend to be clustered in the cities rather than the rural areas. Various forms of Christianity, from Roman Catholicism to the independent churches of William Wade Harris, and Albert Atcho, have gained a significant following among the Akan and Lagoon people, while Islam finds followers among Mande-and Gur-speaking people (Kouadio and Gottlieb 1997). As for the immigrants, they normally retain their original beliefs and practices, although some are affected by their new environment and may opt to join a new religious tradition. Despite this heterogeneity of the Ivoirian population these groups were able to live side by side for nearly four decades without major clashes (Kouadio 2007). Table 3 below shows the various religious faiths and their distribution by percentage, as well as the regions where they are mostly practiced. 
Table 3: Major Religions

\begin{tabular}{|c|c|c|}
\hline RELIGION & PERCENTAGE & LOCATION \\
\hline Muslim & $35-40 \%$ & Mostly north, but also other regions \\
\hline Indigenous & $25-40 \%$ & Widespread across the country \\
\hline Christian & $20-30 \%$ & Mostly south, also other regions \\
\hline $\begin{array}{c}\text { Foreigners } \\
\text { (Muslim) }\end{array}$ & $70 \%$ & Mostly south, also other regions \\
\hline $\begin{array}{c}\text { Foreigners } \\
\text { (Christian) }\end{array}$ & $20 \%$ & \\
\hline
\end{tabular}

Source: Adapted from CIA Fact book (2001)-Côte d'Ivoire

Politically, Côte d'Ivoire has been run by ethnic Baule, Bete and Dyula leaders, though French influence remains significant. Felix Houphouët-Boigny, a Baule from Yamoussoukro (center), was its first president, and he remained in this position until his death on 7 December 1993 at the age of eighty-eight. Baulin (1980 and 1982), Amondji (1984 and 1986), Siriex (1986), Tiemoko (2000), Jackson and Rosberg (1982), and Cohen (1974) have extensively written about the life of President Houphouët-Boigny and the history of Côte d'Ivoire. There is a large consensus among these scholars that the life of the president and the history of his country were so intertwined that it appears almost impossible to separate the two. In fact, Jacques Baulin, a former advisor to the president, called him "Monsieur Côte d'Ivoire." In other words, one could not talk of Côte d'Ivoire without referring to Houphouët-Boigny and vice-versa. This also gave an indication of the tight control the president enjoyed over his country and people. But, where did the president derive all this power, and how did he manage to maintain unity, to remain wellconnected to his people? 
Houphouët-Boigny's initial rise to power started during the colonial era when he first served as an African physician (médécin Africain) in various regions of the country (Aboisso in the southeast, and Guiglo in the west). Then he became the head of his family and traditional chief of the Akwe people (his native tribe) after his maternal uncle Kouassi Ngoh died. Some years earlier, he had studied medicine in the prestigious colonial school of William Ponty at Gorée, Senegal (Houphouët-Boigny 1994: 55).

It was French colonial Governor Lapalude of Côte d'Ivoire who invited the young physician to take over the position of his deceased uncle, a loyal chief and servant to the French colonial administration. Houphouet-Boigny then resigned from his position to lead his family and his native tribe, also serve the interests of the colonial administration. He was set to become a wealthy man, and to have an illustrious, bright, and long political career. First, he inherited a huge amount of wealth from his family, and the colonial administration, which he later used during his political struggle against his political opponents. He also claimed all the cocoa, coffee, and tobacco plantations, as well as assets from his deceased brother Augustin Dia, and his uncle Kouassi Ngoh. Quickly, the former African physician became a wealthy man, and a big African planter (HouphouëtBoigny 1994: 75).

During his tenure as president, Houphouët-Boigny was a fine politician who was capable of combining intelligence, risk taking, confidence and hope, by navigating sharply between traditional and modern ways of governance. Admirers such as Coulibaly (1975) and Zan (1986) among others have referred to him as the most prominent politician of his time in Sub-Saharan Africa. They described him as clever, opportunistic, and very energetic, and his political career filled with important achievements. Moreover, 
Houphouet-Boigny was identified with the anti-colonial movement through the Rassemblement Démocratique Africain (RDA), a regional association of which the Democratic Party of Côte d'Ivoire (PDCI) he created was a local chapter (Amondji 1984: 9-10 and Appiah 1993).

In his part, Crowder (1978: 225) writes that French colonial rule in West Africa ended in the early 1940s. That during the decolonization process (1944-1960) Houphouët-Boigny was backed by France, and had the guaranteed support of the traditional chiefs against radical politicians. This author adds that his education and other responsibilities had earned him a good deal of respect, which I explained below.

In 1930, he married his first wife, a royal Agni descendent with a Senegalese father. The Agni people live in the southeast region (see map in Appendix A, p.217) and are highly respected by other groups. They have a kinship system that goes hundreds years back. Thus, Houphouët-Boigny acquired kinship ties with another Akan group, and also the foreign African community (Houphouët-Boigny 1994: 62).

In 1940, he organized the Association of Customary Chiefs (Associations des Chefs Coutumiers), thus extending his influence among traditional leaders throughout Côte d'Ivoire (Baulin 1982: 25). In 1944, he organized the African cocoa and coffee growers' union (Syndicat Agricole Africain) in Côte d'Ivoire. Through this mechanism, he joined together large numbers of people from various ethnic groups who relied upon him for representation. These activities reflected his ability to create a wide network of popular and political support (Mundt 1987: 83).

Mundt (1987: 10-11) observes that, in Côte d'Ivoire, the politics of independence began after World War II. Political activity began in the trade unions, ethnic and other 
associations in the towns, and in a farmers' union ahead of the elections. It was a coalition of these organizations that sent Houphouët-Boigny to the Constituent Assembly in Paris (see also Campbell, 2003). Amondji (1984: 19) also writes that while in France, Houphouët-Boigny succeeded in lobbying for and obtaining the abolition of forced labor, which gave him the undisputed prominence among the Ivoirian electorate. He then came back to his country to participate in the formation of the PDCI, drawing support from the union of African planters and other groups.

In 1946, Côte d'Ivoire and other territories joined with France in the French Union, giving Houphouët-Boigny another opportunity to excel and shine among his peers. The same year saw the birth of the RDA, a regional party encompassing all of Francophone Africa with affiliated groups in each colony (Worster 1989).

By 1950, Houphouët-Boigny emerged as the undisputed leader of the PDCI, and the obvious choice as spokesman for his country while it moved toward independence in 1960 (Mundt 1987: 84). In 1956, he was successively named mayor of Abidjan, and he entered the French government at the ministerial level (Legum 1965).

After a negotiated independence with France, he became Côte d'Ivoire's first president on 7 August 1960. He was then re-elected again and again without any opposition in 1965, 1970, 1975, 1980, 1985, and 1990 (Lye 2003). Though, the 1990 political context was different as multipartyism had officially been authorized in that country for the first time. Houphouët-Boigny largely won against a weak opposition led by his long time political opponent, Laurent Gabgbo.

As I mentioned earlier, Houphouët-Boigny played key roles as an educated leader, modern politician, and traditional chief during career. This navigation of identities 
ensured his position locally, regionally, and even worldwide. He even intentionally manipulated the Constitution to ensure the smooth transition to Bédié's (formerly president of the National Assembly) rule upon his death (Bakary 1984, Wauthier 1997, and Wiseman 1995). He was groomed to be the next president based on the constitutional provision should the president died. Ironically this was the case.

But, most analysts and Ivoirian people remain divided over the president's legacy. On the one hand, admirers such as Xavier (1971), Baulin (1980 and 1982), Zan (1986), Siriex (1975 and 1986), and Coulibaly (1975), have attributed the long period of stability to his skillful political maneuver, open-door and immigration policies towards the neighboring states during the economic boom of the 1960s and 1970s, and strong ties to the West, especially France. On the other hand, his major critics such as Gbagbo (1980 and 1983), Kourouma (1970 and 1978) have denounced the president's repressive tactics against his political enemies. Both Gbagbo and Kourouma had been imprisoned by the late president for their hash criticisms against the absence or lack of democracy during the single-party regime era. In fact, most Houphouët-Boigny supporters viewed or portrayed Gbagbo as rude, and someone who dared to challenge the authority of the old and autocratic president. In the end, they both were forced to exile to France, where Kourouma died.

Indeed, numbers of events happened under the one-party rule, which were not all perceptible on the surface. Some painful events had occurred under Houphouët-Boigny's watch. These events included: (1) the Guebie rebellion of 1969-70 in which entire Bete villages were wiped out by the army in Gagnoa region, (2) political opponents such as Ernest Boka, Biaka Boda, Kragbe Gnagbe, and Jean-Baptiste Mockey, who were brutally 
suppressed or had lost their lives under very strange circumstances, (3) student activists (including Laurent Gbagbo) who were enrolled by force in the military and sent to a notorious camp in Seguela (northwest) as punishment for the rebellious actions toward the regime, (4) and the numerous alleged plots (faux complots) used by the president to attack his opponents. In some instances, some of these so-called political enemies, or suspected troublemakers were named Ambassadors to far away countries. An example of this was army General Bertin Zeze Barouan, a Bete from the west, who was named Ambassador to Brazil without any formal training in foreign affairs. These events, however, did not play a significant role on the national scene. They were seen by many as an act correction, especially those loyal to the former regime.

Despite these events which should not be minimized, it is undeniable that Côte d'Ivoire's initial impressive economic success and political stability during the early years of independence was owed to the vision the president had for his country. As Rothchild et al. (1996) and Baulin (1980) have argued for, he believed in a unified, stable, and modern state built on a solid base of agricultural export, translated by an open-door policy throughout the region, which attracted foreign migrant workers in the cocoa and coffee plantations, owned first by the local planters. Gradually, some of these migrant workers were able to purchase some land and grow their own cocoa and coffee, thus some of them settled permanently. Côte d'Ivoire became the world largest producer of cocoa, and it occupied a high rank in coffee production also (Hecht 1983, Nyong'o 1987, Amin 1970, den Tuinder 1978, and Brayton 1979).

Unfortunately, the relative economic prosperity of the early years of independence could not be sustained because of some internal and external forces which 
are described below. The system in place started to fall apart, and the country needed political reform and economic change (Toungara 1986), the so-called economic 'miracle' started to tarnish (Bourke 1987), and the ideology of development in place was heavily challenged (World Bank 1987, Young 1982, Rapley 1993).

In fact, the official local newspaper, Fraternité Matin (2003), argues that between 1980 and 1990, the fall of the price of cocoa and coffee occasioned a fatal downfall of the Côte d'Ivoire's economy. All the sectors of the economy were impacted severely, especially the agricultural sector. As a result of the economic downturn, many people could not afford to send their children to school, and buy basic goods, including medicine. Moreover, their habits and lifestyles changed dramatically creating anger, frustration, and general misery. Expectedly, this had put enormous pressure on the government both internally and externally. Domestically, the number of the discontents grew significantly. Externally, there was a lot of pressure from the foreign debtors, including the IMF and World Bank.

On 25 May 1987, the government announced it could no longer pay its foreign debt, which was estimated at 6 billion U.S. dollars, forcing it to accept and implement some painful policy prescriptions in the form of structural adjustment programs imposed by the International Monetary Fund and World Bank. These adjustment programs of the 1990s have received much attention from analysts such as Bratton and van de Walle (1997). The initial phase of these adjustment programs was to stabilize the troubled economy. The second phase consisted of reforming the economic and financial sectors, which in turn will stimulate growth. The expectations behind this were that part of the 
revenues generated would serve to repay the country's foreign debt, and ensure the financial security of the people.

Hence, in 1989, the World Bank required that the national economy be made competitive by depreciating the exchange rate and improving the public finances, and resulting in a significant increase in unemployment, which was already high, due to the closing of many factories around the country. Moreover, the government proposed to reduce the salaries of the workers in the same year. In Sub-Saharan Africa the government is the major employer, and a civil servant feeds more than his or her own nuclear family (husband, wife, and children). It was clear that cutting the salaries would have dramatic consequences on those workers and their dependents. Expectedly, these measures provoked huge social protests in Abidjan and elsewhere in the country, forcing the government to review its first round of adjustment measures. It tried without success to find new ways that would be less painful. Each time it met the opposition of the people.

Meanwhile, the opposition led by Laurent Gbagbo began pressing for multiparty democracy and the organization of transparent and fair elections in the same year (Conteh-Morgan 1997). During these difficult moments, Fraternité Matin (2003) argues, President Houphouët-Boigny was caught between the demand from the foreign aid donors on the one hand, social organizations, and political opposition on the other hand. But, the government had to take courageous decisions to save the country from plunging further. It was in this context that president Houphouët-Boigny called upon Allasane Dramane Ouattara (also called ADO), a former Governor of the West African Central Bank in Dakar (BCEAO), who was serving as Deputy-Director of the African Division at 
the International Monetary Fund in Washington D.C., to inject some shocks into the Ivoirian economy (Konate 2004).

In April 1990, Ouattara led the Comité Interministériel de Coordination du Programme de Stabilization et de Rélance Economique to oversea the adjustment program. On 7 November 1990, he was named prime minister, the first in Côte d'Ivoire's history. However, the honeymoon between the new prime minister and the people did not last long. Rumors about his identity were being circulated around the country. According to Fraternite Matin (2003), it was alleged that the former Deputy-Director of the IMF in Washington D.C. (1984-1988) had worked with a Burkina Faso passport. As a result, this made him a non-Ivoirian or alien to that country. But, nobody could voice this officially as, Houphouët-Boigny, although physically diminished, was still dominating the political machine in Côte d'Ivoire.

Ouattara went ahead and designed a number of important, but unpopular measures. According to the same newspaper, the first set of measures included: to reduce the number of government vehicles per ministry; to force the wealthy barons of the old regime and private sector to pay back taxes accumulated over the years (especially telephone, water, electricity, and personal properties), to supress the gratuity of University buses that used to be free for all the students, and privatize both government owned and semi-owned companies. Unfortunately, this austerity measures did not yield the expected results either for the government's coffer remained empty.

Ouattara then added new measures to the list. For example, he decided to reduce the salaries of all the new teachers for all the levels of the education system by $50 \%$. This 'unjust' decision sparked a huge public outcry among new and prospective teachers. 
Next, Ouattara introduced for the first time the controversial Alien Identification Card (Cartes de Séjour), whereby every national from the Economic Community of West Africa States (ECOWAS) or (CEDEAO in French) was required to pay the equivalent of 5,000 F CFA (7.6 Euros) per year, while other immigrants outside this organization must pay 50,000 F CFA (76.2 Euros) annually, as a resident alien (Fraternité Matin 2003).

At that point, these structural adjustment programs had set the stage for mounting and long social unrest throughout Côte d'Ivoire. The system could explode at any time. Nobody knew when it can collapse for sure. Between 1990 and 1991, the country experienced huge mass protests and strikes by students, police, customs officers, University professors, transport workers, professional associations, and this climaxed by the takeover of the airport by army conscripts in 1990 .

Akindes (2000: 126) and Kieffer (2000) have documented the different activities of the military during that period, while Cogneau (2003: 87), Toungara (1999: 23), and Bratton and van de Walle (1997) have written extensively on the social implications of these adjustments on the African continent in general, and Côte d'Ivoire in particular. As one scholar has observed, all of these protests were a direct response to the appalling and poor economic diet imposed on the country by the IMF and the World Bank. Côte d'Ivoire, like many African states and the developing world had badly failed its structural adjustment programs test with the Breton Woods Instititutions.

For a while Ouattara and his drastic measures were the center of all the daily conversations throughout the country, especially in Abidjan the economic capital. Those barons who were summoned to pay back taxes disliked Ouattara so much. In the end, these structural adjustment measures, which were intended to improve the economy in 
the first place, brought significant political and social turmoil to Côte d'Ivoire and its people. Among other things, they gave the average Ivoirian the opportunity to break certain taboos of the past including: defying the authority of the government, speaking freely and publicly about local politics, and most importantly speaking against the autocratic president (Houphouët-Boigny), something which was unthinkable before. It has also been argued the introduction of the Alien Identification Card by Ouattara led to the current xenophobia or ultra-nationalism toward foreigners (Fraternité Matin 2003). The next section discusses the political development immediately proceeding.

\section{Political Developments Immediately Proceeding}

To many attentive observers, it was clear even in 1990 that Côte d'Ivoire was set to face many challenges both economically and politically. Economically, although there were some improvements in part of 1998, the majority of the people however remained unhappy with the government that continued to struggle with its foreign financiers. Konate (2004) argues that, politically, tension grew greater and greater among the people, especially with the entering of Ouattara on the Ivoirian political arena in 1990.

Meanwhile, the sick president's health started to deteriorate at a hospital in Paris, and rumors of his death spread quickly all over the country.

Finally, on 7 December 1993, Houphouët-Boigny was officially pronounced dead during a nationally televised address read by then Prime Minister Ouattara. Sadly enough, the mourning of the late president did not last long, as the battle for the succession between the various contenders (mainly Ouattara and Bédié) was already underway (Wiseman 1995 and Wauthier 1997). 
Article 11 of the Ivoirian Constitution stipulates that in the advent of a vacancy of the presidency, the president of the National Assembly takes over the mandate of the deceased or ill Head of State. Despite this constitutional provision, the president's death provoked a friction between Ouattara (former Prime Minister) and Bédié (former President of the National Assembly). After Houphouët-Boigny died, Ouattara immediately called for a national council (Conseil d'Etat), to allegedly block Bédié from taking over. Ouattara's attempt to disregard the law spurred Bédié to quickly proclaim himself president (Konate, 2004).

Meanwhile, a dissident group from the old Democratic Party of Côte d'Ivoire (PDCI) created in 1994 the Rally of Republicans (RDR) led by the late Djeni Kobina, an Abron from Bondoukou (northeast). Kobina was later joined by other important figures from the old party: Henriette Dagri Diabate, a native of Jacqueville southwest, who had held several positions in former cabinets under Houphouët-Boigny, and Ouattara, who had become the emblematic figure and president of that party since $1^{\text {st }}$ August 1999 following Kobena's death. The fight between the two main contenders went on and quickly spread among their respective followers and partisans.

Bédié legally won the first round of the war of succession by taking over the mandate of the deceased president. He won again the second round for during the 1995 presidential elections Ouattara did not ran on the ground that the law voted by the National Assembly on 8 February 1994 disqualified him or it did not allow him to do so (Konate 2004). The 8 February 1994 law roughly states that: “All presidential candidates must be Ivoirian, whose parents must also be Ivoirian born.” Ouattara’s legal disqualification allowed Bédié to easily be elected with 95\% of the ballots in 1995 . 
Meanwhile, the political opposition, workers union, and student movements continued to press for better living and working conditions. On February 1992, a huge protest organized by the opposition was severely repressed by government forces under Ouattara's watch, as the prime minister. During these demonstrations, current president, Laurent Gbagbo, then Secretary General of the Ivoirian Popular Front (FPI), was arrested, jailed, and convicted on 6 March 1992 to two years in prison along with his wife Simone, and other important leaders of his party. Gbagbo was finally released on $1^{\text {st }}$ August 1992 (Afrique Contemporaine 2000, Politique Africaine 2003, and Nouveau Revéil 2003).

When Ouattara was elected president of RDR, he declared his candidacy for the 2000 elections, knowing that the law that had disqualified him in 1995 was still in effect. There are two possible explanations to Ouattara's bold move to declare his candidacy for 2000 despite all his legal troubles. One explanation is that he had been challenged, frustrated, humiliated, and defeated twice by Bédié, thus he sought revenge. As the president of his party, he could count on either one or a combination of the following: (1) the support of important dissidents from the old party (PDCI) who did not support Bédié, and (2) the support of RDR influential leaders from the north who were Muslims like him. Capitalizing on the latter group may be crucial in that it provides not only a large following from the Muslim north, but also foreigners (majority of whom are Muslims), and also victimized by the system. A second explanation of Ouattara's move to declare himself as candidate in 2000 despite the law is that he thought he could legally challenge the Electoral Commission about his origins, and finally establish the truth about his identity. 
In fact, in order to respond to his detractors, he had applied and obtained an identification certificate (Certificat d'Identité) delivered by Judge Zoro Bi Ballo in Dimbokro (center), where he was allegedly born in 1942. Expectedly, the authenticity of that certificate had been questioned by the authorities, which did not want him to participate in the 2000 presidential race, and perhaps no elections at all. Instead, they claimed that he had forged a legal document. When the story became public, pro-RDR members took the streets to express their anger and frustration. Ironically, the same law (Loi Anti-Casseurs), which had banned all public demonstrations while Ouattara was Prime Minister, was still in effect. Under this statute, many demonstrators were apprehended and sent to jail. Tension then escalated between pro-RDR members and the Bédié regime even further.

Meanwhile, Bédié had published a book titled: Les Chemins de Ma Vie (The Paths of My Life) in which he viciously attacked Ouattara for interfering with Ivoirian politics in the following terms: "Burkinabè by his father, he did not have to interfere with our business of succession" (Konate 2004). This message of exclusion drew even more support from the northerners, and Muslim populations for whom Ouattara had become an icon, representative, spokesman, and leader. Furthermore, the immigrant population from the Sahel region (namely Burkina Faso, Mali, Niger, and Chad, etc...) who were being abused by the security forces saw in him a potential liberator. At that point, the war of succession had reached its pick, which each side decided to win at all costs.

Ironically, soon after he became prime minister, Ouattara had accepted an invitation to face the nation in a televised interview, to discuss his new position as Côte d'Ivoire's first prime minister, and reveal his true identity to the public and, perhaps, 
dissipate the rumors about his origins. The interview was a great opportunity for Ouattara to confront the nation, and discuss not only his identity, but also the burning socioeconomic issues during that time.

Raphael Lapke, the moderator, who did not shy away from these explosive topics started this way (quote from Fraternité Matin 2003): “A Jeune Afrique article published on 8 August 1984 stated: Allassane Ouattara, a citizen of Upper-Volta (now Burkina Faso), of Voltaic parents who had immigrated to Côte d'Ivoire, has been named DeputyDirector of the African Division of the International Monetary Fund (IMF) to replace a Zambian.”

The reading of that article set the stage for some more direct questioning or cross examination which is to follow: "My question to you is the following. Mister Prime Minister, in 1982, you were a citizen of Upper Volta. Between the priod 1985-1986, you adopted the Ivoirian citizenship. In 1990, you were appointed Head of the Government of Côte d'Ivoire. I would like to ask you a question which is twofold: First, what where the reasons for this choice? Second, do you think that you have a strong sense of nationalism like other fellow Ivoirians to make the necessary sacrifices that the current economic situation requires for our country?" The questions asked reflected the rumors that were circulating in the streets, offices, and households about Ouattara's alleged Burkinabè origins.

Following that interview, Fraternité Matin (2003) claimed that Ouattara did not provide convincing responses to the nation. That, his apparent silence provoked even deeper suspicion among the people, especially politicians, some of whom did not want him to run for any public office in the country. Furthermore, in a desperate attempt to link 
him to the current civil war, Fraternité Matin (2003) published several statements that Ouattara had made during his moments of deep anger and frustration, especially against the Bédié regime (see also Konate 2004).

Note that some of Ouattara' statements have been used and manipulated by some local news outlets and political leaders to try to explain who was actually behind the rebellion in Côte d'Ivoire. The most popular lines included: "When the time comes, I will hit this shaky regime (Bédié's), and it will fall... No one can govern Côte d'Ivoire by arresting the people everyday, violating the rights of journalists, businessmen (...), Côte d'Ivoire is no longer a lawful state (...), I will return before the end of the year (1999)." Ironically, the first coup that brought General Guéï to power came on December 1999. During my doctoral research to Abidjan in 2003, I realized that the average Ivoirian and politicians alike had already concluded that Ouattara had played a role in the 1999 coup which overthrew Bédié, and also the September 2002 civil war, although they had no evidence to prove or support such claims. Others blamed the former colonial power (France) for the crisis.

To be sure, FPI leaders like Koulibaly (2000), and pro-Gbagbo local newspapers (Le Courier d'Abidjan 2004, Le Temps 2003) have blamed the former colonial power. They claimed that France did not like the Gbagbo regime because it did not renew the license or contrat of the major French companies operating in that country. They also claimed that France did not like the fact that Gbagbo extended the Ivoirian market to other foreign nations or competitors such as China, the United States, Japan, and others. It should be noted that the French own significant shares in the telecommunication, water, and energy industries among other things since independence. A small group of 
Ivoirians also blamed Burkina Faso for allegedly served as training ground and safe heaven for the rebels before the attack of September 2002. In fact, during the early months of the rebellion, President Gbagbo himself blamed that country and its authorities for allegedly providing some "tacit" support to the rebels.

From virtually 1990 to 2002, Côte d'Ivoire went through so much tumult and political animosity, that it was predictable that the war would come sooner or later. The war broke out on the night of 19 September 2002 after a long period of relative stability. The failed coup was made by rebellious exiled military who attacked simultaneously FPI leaders's compounds, and military and security facilities in Abidjan (south), Bouaké (center), and Korhogo (north). The rebels named themselves Patriotic Movement of Côte d'Ivoire (MPCI). Later, two new rebel groups emerged—The Ivorian Popular Movement for the Great West (MPIGO) and the Movement for Justice and Peace (MJP). MPIGO and MJP were allied with the MPCI, and the three groups subsequently called themselves the New Forces (Forces Nouvelles, or FN).

The failed coup evolved into a rebellion that split the country in two parts. The rebels occupied the north and far west, while the rest of the country (mostly south) remained under government control (see conflict map in Appendix B, p. 214). The war has since escalated into Côte d'Ivoire's worse crisis since independence. It all happened in the context of a failed democratic experiment, first the coup of December 1999, and civil war in 2002. The political context of the civil war was set by the contested mainly by the 2000 presidential elections, when a controversial Supreme Court decision disqualified fourteen of the nineteen candidates, including all of the Ivoirian Democratic Party (PDCI) and Rally of Republicans (RDR) candidates (Toungara 2003). 
According to Toungara (2001), the PDCI and the RDR boycotted the elections. Before the results were tabulated, Guéï suspended the Electoral Commission and claimed victory. Gbagbo rapidly proclaimed himself as president, and called his party militants to take the streets to show support. These angry and violent protesters forced Guéi into exile on 25 October. Furthermore, despite the exclusion of other candidates and the low voter turnout of 37 percent (compared to 54 percent for the referendum), Gbagbo held his ground. The Electoral Commission later confirmed his victory with 59.4 percent of votes cast to Guéi’'s 32.3 percent. Toungara notes that upon his installation, Gbagbo launched another round of political repression by the security forces, as did Bédié and Guéï. The legislative elections of 10 December 2000 repeated the debacle of the presidential balloting.

Toungara (2001) writes that the U.S. Department of State's Country Report on Human Rights 2000 gave details of numerous human rights violations that began under Bédié and continued during several months under Gbagbo. Due to the mounting evidence of human rights violations against northerners, the incentives for the emergence of a united northern opposition grew stronger. When the RDR elected Ouattara to head their party upon his return to Côte d'Ivoire in July 1999, and selected him as their presidential candidate, northerners pledged their support in solidarity. Gbagbo allowed the murders and other kinds of abuse to go unpunished, as security forces continued to terrorize civilians. All this abuse and suffering of the people finally resulted in Côte d'Ivoire's socio-political and military crisis on September 2002, which some had predicted. 


\section{Overview of the Remaining Chapters}

The second chapter of this dissertation reviews the literature on civil wars (in general), and discusses what kind of civil war the Ivoirian civil war is. From the different taxonomies that are available in the literature, it identifies that the civil war in Côte d'Ivoire is outwardly one among the countries ethno-regional groups. Then it outlines the debate between cultural pluralism and political economy approaches, domestic-oriented explanations (materialists and resource opportunity approach) and international political economy approach (structural adjustment programs), and international pressures approaches (western democratization, French pressure and patron-client relations with France, and regional pressures).

The third chapter examines the domestic and international political economy as a source of civil violence in Côte d'Ivoire. It examines the correlation between the civil war and people's income levels to see the trend after President Gbagbo came to power. In other words, did socio-economic grievances stimulate the fighting? I use the following empirical questions: Did the population become poorer? Were the people uncertain about the future? Did the size of the middle class shrink? Was there a decline in the socioeconomic indicators of the people? If the population got poorer in the 1990s, what effect did this have on civil violence? Did this have to do with the effects of structural adjustment programs, falling of cocoa and coffee prices on the world market, or a combination of the two? What resources did the rebels go after and how they have used them to support themselves? Or how did their military and political strategies change as the situation progresses? 
The fourth chapter looks at the role of ethnicity and region as identities of the civil war. It seeks to explain how have ethno-regional differences shaped the civil war in that country? First, I examine the ethno-regional composition of the competing military forces. Second, I discuss how were the various ethno-regional groups able to live together in such harmony up to 1993 ? That is, what did stimulate the previously quiescent ethnopolitical forces to take up arms against each other?

The fifth chapter analyzes the role of the foreign relations in the civil war, as well as the regional political context. It seeks to understand whether the war broke out because France withdrew its support from President Gbagbo, or was hostile to the Gbagbo regime in a way that it was not to the regimes of Houphouët-Boigny, Bédié, and Guéi? I also look at whether or not French aid declined or drop off precipitously after Gbagbo's election in 2000 , or if the French rhetoric changed after Gbagbo came to power? If yes, when and how, sending a signal to would-be rebels? This chapter also seeks to know if the war broke out because the neighboring countries encouraged the rebellion. I use the following three empirical questions: did France signal to these neighboring countries that their intervention was acceptable? Or did these countries have their own reasons for intervening in the conflict? Why such intervention was thinkable under Gbagbo, but not previously?

The concluding chapter distinguishes between proximate and root causes of the Ivoirian civil war. Here I make judgments about the relative weight of the various causes, or the extent to which the weight of the causes can be measured. I want to know if it is possible to give an empirical answer to the question of why the war began. Can one explain the war, and demonstrate with scientific precision which causes were primary? 
Finally, I want to know what does the comparative evidence from other recent wars in Africa that began under similar circumstances, have to tell us about Ivoirian war? 


\section{CHAPTER 2}

\section{LITERATURE REVIEW}

When the former Soviet Union collapsed in the early 1990s, it was hoped that the new world order would bring both political stability and economic prosperity to all the regions of the globe. In fact, some regions have experienced positive developments and stability since that time, while in most of Sub-Saharan Africa it seems the new order has served as catalysis for renewed violence and non-development. The highest numbers of contemporary civil wars and casualties have occurred in this part of the world.

There were nearly a hundred civil wars worldwide between 1989 and 1994 alone. An estimated 80,000 people died during that period (Gurr 1994, Wallersteen and Sollenberg 2000). The majority of these conflicts had a strong ethnic dimension to them (Russets and Starr 1989: 1, Lobell and Mauceri 2004: 1). The regions with the highest number of ethnic rivalries included the Middleast, parts of Asia, and of course SubSaharan Africa.

Michael Brown (1996: 235) shows how grim the situation was across several SubSaharan African countries. According to him, between 1991 and 1993, an estimated 400,000 people died from war-induced famine in Somalia, while nearly 800,000 Rwandans fell victim to the 1994 genocide. In Angola, the civil war that resumed in late 1992 reached a death toll of 1,000 per day. In Liberia, nearly half of the population of 2.5 million died or fled the war zone. Similar tragedies occurred in Sudan where nearly 1.2 million people died from famine and civil war since 1984, while in October 1993, well over 100,000 people lost lives in Burundi during a month ethnic bloodshed. 
Unfortunately, several Sub-Saharan African countries have followed suite or fallen victims to civil war since these statistics were first tabulated. Some of these socalled new civil wars were least expected due to the relative stability that reigned in these countries including: Kenya and Côte d'Ivoire. It should be emphasized that, in general, many contemporary civil wars have occurred in the context of political reform, and especially around electoral issues. Their numbers are likely to increase dramatically due to the unpredictable nature of the political culture in that part of the globe as recently seen in Zimbabwe, Central African Republic, Congo-Brazzaville, and Guinea-Bissau. But, what led to the violence and misery that Angola, Rwanda, Somalia, Sudan, Sierra Leone, Côte d'Ivoire, Kenya, the DRC, and others have experienced?

Scholars dealing with this complex subject can be divided into two big camps. On the one hand, there are those who have used quantitative methods to try to explain the incidence of civil wars around the world. The works of these scholars basically consist of using numerical data, run regression analyses, and to generate findings. On the other hand, there are those who have used qualitative methods to try to understand and explain why do civil wars occur? The scholars in this latter category often put an emphasis on the root and proximate causes of civil wars to draw their conclusions (Ross 2004: 337).

While both camps have been somewhat successful in generating important findings and explanations, their contributions have also shown some weaknesses or flaws in them. In fact, some findings have been easily challenged or dismissed altogether, and some interpretations have been labeled one-sided, ambiguous, or simply confusing.

However, there is a large consensus among scholars that although civil wars may have basic similarities, they often have fundamental differences. For instance, some civil 
wars involve two or more identity groups within a country (Rwanda, Liberia, Sierra Leone, Somalia, and Sudan), while other civil wars involve one or more ethnic groups and the State (Uganda, Côte d'Ivoire, and the Democratic Republic of Congo). Some civil wars have an international dimension to them, belonging to one or combination of the following four scenarios: (1) the rebel groups are directed by outside forces (namely a foreign country or individuals living in exile), (2) the rebels or government forces use foreign mercenaries in their ranks, (3) foreign peacekeepers take side in the conflict, as the Nigerian and Ghanaians soldiers did in Liberia in the 1990s, (4) and spillover effects due to refugee movements, regional insecurity, looting inside a neighboring country that often force it to intervene in others conflicts.

Another important characteristic is that rebellions tend to vary across countries, in their internal composition, size, duration, and goals. Some rebellions are well organized than others, some rebel groups are better-equipped than others, some rebellions have a large following while others do not, some rebellions are long-lasting and difficult to overcome while others are easily crushed, few rebel groups are able to achieve their initial goals while the majority do not succeed. The literature suggests that these specificities are extremely important, and therefore this must be taken into account in order to have a full understanding of the situation on the ground. Knowing these details clears up some of the ambiguities and confusions about civil wars in general and African civil wars in particular.

The goal of this chapter is to review the literature on the causes of the civil wars, and let each category of approach generate hypotheses about the Côte d'Ivoire case. The overall goal of the entire dissertation is to try to understand why did the civil war in Côte 
d'Ivoire occur? This in turn should inform the theoretical literature. The present chapter reviews the literature on civil wars in general, and it discusses what kind of civil war Côte d'Ivoire's civil war is. From the different taxonomies that are available in the literature, this chapter identifies that the civil war in Côte d'Ivoire is outwardly one among the countries' ethno-regional groups. Then it outlines the debate over the causes of civil wars, specifically cultural pluralism and political economy approaches; domesticoriented explanations (materialist and resource opportunity approach) and international political economy approach (structural adjustment programs); and international pressures approaches (western democratization, French pressure, patron-client relations with France, and regional pressures).

\section{A. Identification of Different Types of Civil Wars}

I have identify five broad categories of the causes of civil wars in Africa, and other parts of the world including: (1) The civil wars in which rebels aim at regional secession, (2) rebels aiming at state dominance of some identity group, (3) rebels aiming at redistribution of wealth and income across classes, (4) ethno-groups seek control of the local resources, and (5) civil wars against foreign colonizers or white minorities.

\section{Rebels Seeking Secession and Control of Resources}

In this type of civil wars the rebels aim at self-determination to form a new state (Collier and Hoeffler 2002: 2-8). These wars have occurred since the 1950s, especially after most countries became independent. Some countries became ethnically united while others were fractures by the colonialism. There are many examples of secession wars around the world. But, their numbers have been limited and their success rate also very low compared to other forms of civil wars. 
In Sub-Saharan Africa, the first and only successful secessionist movement did not succeed in Eritrea until after a combined force of the Ethiopian People's Revolutionary Democratic Front (EPRDF), and the Eritrean People's Liberation Front (EPLF) toppled the central government of Ethiopia in 1991 (Bøas and Dunn 2007: 9). There were several unsuccessful secession attempts in many parts of Sub-Saharan Africa since the early 1960s, yet this has not deterred the secessionist aspirations of certain communities in Angola and Senegal.

In West Africa, there was the Nigerian civil war or Biafran war (1967-1969) in which the Ibo southeast region declared its independence from Nigeria. More than a million people lost their lives. It took four years of warfare for the Nigerian national army to finally crush or overcome the insurgency (Payne and Nassar 2006: 283).

In Central Africa, the people of the mineral rich region of Katanga tried unsuccessfully to separate from Congo, while in the Horn of Africa southern Sudan continues to battle against the Islamic north. To this date, there still exist two low-level insurgencies in the region involving the people of Casamance and Cabinda. The former seeks self-determination from Senegal, while the latter wants autonomy from Angola. These low-levels conflicts not only threaten the stability of the region, but also constitute the seeds for future civil wars.

In Western Europe, several communities have also attempted to secede in the past, some of which were violent, while others appeared to be peaceful. Examples of this are the Basques of Spain, Walloons of Belgium, and Corsicans of France. The case of the Basques has received more attention in recent years due to the terrorist actions perpetrated by ETA against the Spanish State. 
In Eastern Europe the Muslim Republic of Chechnya tried to break away from Russia after the Soviet Union officially collapsed in 1991. In 1994-1995, Russia sent in a huge military force or expedition that destroyed the Chechen capital. After it faced fierce resistance from Chechen nationalist guerrillas, and Russia withdrew in defeat. In 2004, hundreds of children died after Chechen terrorists took over a school and held them hostage (Golstein and Pevehouse 2007: 126). When Yugoslavia broke up in 1991-1992, several republics declared their independence as separate states. Serbia seized effective control of significant areas of Croatia and Bosnia that contained Serbian communities or linked such populations geographically. Non-Serbian populations in these areas were driven out or massacred-ethnic cleansing, while Czechoslovakia split into the Czech Republic and Slovakia in a cooperative manner. In 2008, Kossovo became independent from Serbia after a long political and military confrontation (Golstein and Pevehouse 2007: 127).

In the Middle East, the Palestinians and Kurds have, for a long time, aspired to have their own states. To achieve this, they developed a strong sense of nationalism and nationalist movement. The Kurdish (Muslims and Sunnis) population has been spread across Turkey, Iraq, Iran, Syria, parts of the former Soviet Union, and European Union States. Some Kurds have struggled to gain greater political autonomy within their various countries, while others are committed to establishing an independent country. Iran, Iraq, and Turkey, for example, have violently suppressed them at one time or another. The American invasion of 2003 gave more autonomy to some of them in northern Iraq. Meanwhile, the Kurdish Workers Party (also known as PKK) has been fighting the Turkish State for complete independence. As aresult of these attacks, Turkey killed 
almost 37,000 Kurds, and more than 3,000 Kurdish villages were destroyed (Payne and Nassar 2006: 297-298). Secession was never a part of the original plan of the rebels in the Côte d'Ivoire case. Their main goal was to wage war against the Gbagbo regime, and topple it if at all possible.

This is directly linked to the control of local resources. This type of war has some elements of the secessionist war where the control of the natural resources is often central. In this case, the rebels have no intention of assuming power. Instead, they tend to establish themselves either temporary or permanently in the country's resources rich areas. Such wars have recently created and expanded the now popular concept of warlordism in some parts of the globe, particularly in the Horn of Africa (Sudan and Somalia). Other examples include the war in Congo-Kinshasa over mines in Central Africa, Sierra Leone over diamond in West Africa, Columbia over cocaine in Latin America, and Afghanistan over opium in Southeast Asia.

However, the main goal of the rebels in Côte d'Ivoire was to overthrow the government in a very short time. The control of cocoa/coffee plantations in the West, and diamond/gold in the northwest region came after the rebels failed to take over Abidjan. When it became clear that the rebels were no longer able to pursue their initial goal, they engaged in the illicit exploitation, pillage of these commodities under their control and sell them cheap in the neighboring countries. In some instance, they took all the production from the local growers by force and sold it for their own gains. The funds collected served to enrich themselves, as well as sustain their movements. Such wars are extremely difficult to end for so much interest is at stake. 


\section{State Dominance of Some Identity Group}

These civil wars against the state are the ones in which the rebels aim at state dominance of some identity group (Clark 2002, Zartman 1996, Brown 1996, Gurr 1970 and 2000, Joseph 1999, Rupesinghe 1992 and 1998, and William 2003). In Sub-Saharan Africa, this type of civil war include the civil wars in Rwanda between 1990-1993, Somalia in the 1990s, Liberia in the 1990s, Congo-Brazzaville in the 1990s, and Angola since 1975 among others. In this case, the people who oppose the state or state policies feel marginalized, or left out. Such wars have contributed to the collapse of countries such as Somalia, Sierra Leone, Sudan, and Liberia (Clark 2002, Mkandawire 1999, and Herbst 2000). Ironically, control of the state is still much sought after and valued, as the experiences from wars in countries such as the Democratic Republic of Congo, Uganda, Rwanda, Liberia, Sierra Leone, Kenya, Zimbabwe, and now Côte d'Ivoire suggest (Bøas and Dunn 2007: 26).

It should be also emphasized that the groups that feel marginalized by the state are sometime regionally, ethnically, or religion based (more so in Sub-Saharan Africa). To be sure, in 2000, ethnic violence erupted in Nigeria when Muslims leaders attempted to impose the Shari'a (or Islamic law) on the Christians living in the north. In fact, between 2000 and 2005 more than 54,000 people were killed in conflict between Muslims and Christians (Payne and Nassar 2006: 283)

In the Democratic Republic of Congo (DRC), the crises opposed numerous ethnic groups, many of which were supported by foreign governments. For example, Uganda supported the ethnic groups that fought against Kabila, ethnic rivalries in Rwanda and Burundi spilled over into the Congo, the governments in Rwanda and Burundi were 
involved in the Congo crisis because the ethnic groups that threaten their stability operated from the Congo, and participated in the Congo war (Payne and Nassar 2006: 277-278).

In Liberia, the Americo-Liberians dominated the other ethnic groups (the Kpelle 20\%, Bassa14\%, Gio 9\%, Mano 7\%, and Krahn 5\%) until 1980. When the AmericoLiberian president, William Tolbert, was overthrown and murdered by a group of soldiers led by Samuel K. Doe, from the Krahn group. Once in power, Doe also allowed the Krahn to dominate the country, just as his predecessor did. The Krahn were soon challenged by an alliance composed of Gio and Mano groups. In late 1990, Doe was captured and tortured to death by Prince Johnson and members of the Gio group. More than 150,000 people (out of a population of 3 million) were killed, 800,000 became refugees in neighboring countries and in Liberia itself (Payne and Nassar 2006: 284-285).

In 1983, the Muslim government in the Sudanese capital, Khartoum, declared that the entire country of Sudan would be ruled by Shari'a (Islamic law) as in Nigeria. The Christians and Animists in the southern part of Sudan strongly resisted Islamic rule by forming the Sudan People's Liberation Army (SPLA) to achieve a secular democratic Sudan. If that could not be done, their goal was to make the south an independent country. To punish them, the government prevented food supplies from reaching the starving people in the south, and also bombed international relief centers.

A similar situation was observed in Rwanda where the Hutu majority was given control of the country by the Belgians at independence in 1962. Ethnic rivalries escalated in 1990 between the Hutu majority and Tutsi minority, when the Rwandan Patriotic Front (RPF) tried to challenge the power structure. Note that the RPF was a guerrilla army that 
defended the cause of the Tutsi minority. Moderate Hutus agreed to share power with the Tutsis in 1993. On April 6, 1994, violence erupted after the presidential airplane crushed for some unknown reasons to this date. The killing intensified thereafter, leading to chaos and destruction (Payne and Nassar 2006: 287).

China has also taken extreme measures and precautions against the minorities that live in regions that contain a large proportion of the country's natural resources (such as oil, coal, copper, gold, iron, lumber, and water) to insure that ethnic groups do not threaten the country's unity and stability. China purposely stationed 1 million troops in its western province of Xinjiang to suppress Uighur separatists, who are Muslims and suspected allies of foreign Islamic extremists. The Uighurs' goal of independence is strongly resisted by China. In the past, the Uighurs have attacked oil refineries, railroads, bridges, and planted bombs on buses, which killed several people. They also killed 16 Chinese police officers in 1997, and have engaged in numerous hit-and-run raids on Chinese institutions. In response, more than 1,000 Uighurs were executed, and about 10,000 arrested. Payne and Nassar 2006: 291)

In Sri Lanka, the most significant ethnic division involves the Sinhalese ( $74 \%$ of the population and Buddhists), and the Tamils (22\% of the population and Hindus). The rest of the population consists of Moors, Europeans, and native people of Sri Lanka known as Veddah. In 1994, President Kumaratunga made a concession to Tamils rebels by offering them regional autonomy in a federal system of government. However, the Sinhalese feared that federalism would eventually lead to creating a separate country for Tamils on the island nation. In February 2002, the government was forced to sign a cease-fire with the Tamils rebel leader, Velupillai Prabhakaran (Payne and Nassar 2006: 
294). Velupillai Prabhakaran was killed in the summer of 2009, after a fierce battle between the Sri-Lankan Army and the separatist movement.

Between 1997 and 1999, ethnic violence spread across the world largest Muslim country, Indonesia. Indonesia has $90 \%$ Muslims, $9 \%$ Christian, while Hindus and Buddhists account for the remaining 1\%. Ethnic Chinese, who constitute a significant minority group (5\% mostly Christian) in much of Southeast Asia, are the main targets of ethnic violence in Indonesia. The economic crisis that occurred between 1997 and 1999 sparked widespread violence against ethnic Chinese. Their homes, churches, and shops were looted and burned. More than a thousand people were killed (Payne and Nassar 2006: 295).

East Timorese, who are overwhelmingly Catholic, resisted occupation by Muslim Indonesia. An estimated 200,000 East Timorese (25\%) died as a result of Indonesian military action, starvation, and disease. Under external pressure, mainly from the UN, President Habibie decided to allow East Timorese to vote on independence for East Timor. However, militia groups in East Timor that favored maintaining close ties with Indonesia began to acquire weapons to intimidate those who supported this idea. After the referendum, militia groups took the streets and indiscriminately killed thousands of East Timorese. Priests, nuns, and other associated with the Roman Catholic Church were systematically hunted down and killed. More than 200,000 people became refugees. East Timor eventually became independence in 2002 .

In Côte d'Ivoire, the civil war that started in September 2002 first opposed northerners and Muslims to the state, but this was modified as two ethnically dominated rebel groups from the west joined in. Thus, it became a war western and northern 
Ivoirians against the state. In other words, it was war of Dyula, Yacouba, and Guere against President Gbagbo's regime.

\section{Rebels Seeking Redistribution of Wealth and Income}

In this kind of civil wars the rebels aim at redistribution of wealth and income across classes. This type of war reflects the wars between the bourgeoisie and the proletariat in the old days, which Marxists and Neo-Marxists were strong critics of. Other examples of such wars include the Nicaraguan civil war of 1980s, contemporary wars in Haiti, and Colombia. Note also that in Rwanda, identity/ethnicity and class seem to overlap, as do politics and class in Haiti. Such wars are very rare in Sub-Saharan Africa. Though the Ivoirian experience provides some room for speculation, as it is believed that that country's resources were not equitably distributed among the citizens. The north part of the country covered by the savannah is not suitable for cocoa and coffee (the country's main export commodities). Thus, most people rely on government handouts and services, which have been inexistent. However, the civil war in Côte d'Ivoire was not triggered on such grounds.

\section{War Against Colonizers}

These wars are referred to as anti-colonial wars, liberation wars, or independence wars, the wars were perpetrated against foreign colonizers or white European minorities. They had occured during and in the aftermath of the decolonization of all the regions of the globe, where Western European colonial powers sought to dominate the local people in all the aspects of life (politically, economically, militarily, and culturally). These anticolonial wars occurred for a variety of reasons including: independence seeking, humiliation and exploitation of the local people, physical abuse and atrocities, rising 
consciousness and nationalism, and so forth. Note that these anti-colonial wars proved very bloody in many regions, resulting in huge losses on both sides. In other instances, the colonizers had no choice but grant independence right away. Where they had military advantage, these colonialists forced the local people to negotiate. These negotiations also allowed the Europeans to maintain influence and certain interests (trade, commerce, defense, etc...)

The sustained armed revolt in Kenya between (to 1960), Angola and Mozambique (to 1975), Zimbabwe (to 1980), Algeria (to 1958), and more recently South Africa (to 1994) are cases in Sub-Saharan Africa that remain vivid to this date (Bøas and Dunn 2007: 15). Early versions of this included the Haitian, Spanish, American, and French revolutions. These kinds of wars are now finished in Sub-Saharan Africa. Though, sporadic tensions have emerged between the white minority and indigenous Africans in Zimbabwe and South Africa over land rights. These were not civil wars, but it is a direct consequence of these past relationships. But, what kind the Ivoirian civil war actually is.

\section{B. Discussion of the Type the Ivoirian Civil War Is}

In the previous section, I stressed that the civil war in Côte d'Ivoire was one among the country's ethno-regional groups. That based on the taxonomies presented in the previous section the current civil war in Côte d'Ivoire started as a category two-war (rebels aiming at state dominance of some identity group) and evolved into a category four-war (ethno-groups seeking control of local resources).

On 19 September 2002, Côte d'Ivoire experienced a failed coup attempt that evolved into a rebellion. The civil war war started by multiple factors, including unfair policies and humiliating treatments adopted by the various regimes after 1993, and most 
importantly the failure of the subsequent leaders to maintain the existing relative national unity. After President Houphouët-Boigny died, a fierce battle ensued over succession matters bewteen Allasane Ouattara and Konan Bédié, the two main contenders for the highest office (Wiseman 1995, Wauthier 1997, Akindes 2003 and 2004, and Bassets 2003).

Article 11 of the Ivoirian Constitution stipulates that in case of a vanancy of the of the presidency, the president of the National Assembly (in this case Bédié) takes over the mandate of the deceased or ill Head of State (Konate 2004). The constitution allowed Bédié to assume power until 1995. Bédié easily won the 1995 presidential elections by $95 \%$ of the votes against a weak opposition, and after Ouattara's candidacy was dismissed on the grounds that he did not conclusively establish that his parents were both of Ivoirian parentage. Ouattara was again disqualified in the 2000 elections by the junta led by General Guéï (Bakary-Akin 1991).

In order to respond to his detractors, Ouattara had applied and obtained an identification certificate (Certificat d'Identité) delivered by Judge Zoro Bi Ballo in Dimbokro (center), where he was allegedly born in 1942. The Bédié regime rejected that certificate claiming he had forged a legal document. There was huge public outcry amongst Ouattara' supporters (Konate 2004, Bassets 2003, and Toungara 2001).

Meanwhile, Bédié had published a book titled: Les Chemins de Ma Vie (The Paths of My Life) in which he viciously attacked Ouattara for interfering with Ivoirian politics, calling him a Burkinabè (Burkina Faso citizen). Bédié also created the infamous concept of Ivoirité, which was aimed at discriminating between who was an Ivoirian and who was not. Apparently, this concept was directed to Ouattara, who was already labeled as alien 
to that country. Ironically, the Ivoirité drew even more support and sympathy for

Ouattara among the northerners and Muslims populations, as well as immigrants from the Sahel Region (namely from Burkina Faso, Mali, and Niger), for whom he had become an icon, representative, spokesman, leader, and potential liberator (Toungara 2001: 63-72, Konate 2004).

When he first came to power, Guéï claimed that he had come to clean up all the mess created by the Bédié regime. He promised to return power to the civilians in a short while. The junta then assumed power for nine months. Unfortunately, Guéi allowed his soldiers to terrorize, to harrass, and to victimize the northerners, Muslims, and foreign immigrants from the Sahel region (Africa Confidential 11 October 2002, Akindes 2003 and 2004, Bassets 2003: 13-27, Toungara 2001, and Konate 2004). Furthermore, he created the Union for Democracy and Peace in Côte d'Ivoire (UDPCI), and he decided to run in the 2000 presidential elections. Unfortunately, he lost to Gbagbo. Once in power, Gbagbo also did nothing to resolve or correct the problems his predecessors had created. Instead, he allowed many crimes to go unpunished (Toungara 2001).

It was in this context of deep confusion and social tension that the country experienced its first ever civil war after thirty-three years of relative stability. The coup was originally led by the MPCI, which was joined later by the MJP and MPIGO. Together, the three groups formed the Forces Nouvelles (FN). The FN consisted of exsoldiers and new recruits from the north (also Burkinabè and Malians), and Yacouba and Guere people from the west (also Liberians). The failed coup split the country into two parts. The rebels occupied the north and far west, while the rest of the country remained under government control. 
The initial goal of the rebels was to overthrow the Gbagbo regime in Abidjan (south). But, because the national security forces were able to push them back during the early moments, the rebels sought to control the north (rich in cattle and cotton), center, western cocoa and coffee belt, northwest (diamond and gold rich area near Seguela), and the port of San Pedro (southwest near the Liberian border). Part of the revenue generated from the sale of these commodities allowed the rebels to sustain themselves or finance their movement. As a result of this the market of the neighboring countries, which did not grow cocoa and coffee, were flooded with these cocoa and coffee. It was also alleged that the rebels had built fancy homes, hotels, and shops in these neighboring countries in preparation of their old days.

Also, immediately after seizure of the north, west, and northwest regions, the rebels broke into several regional West African Central Bank branches in Bouaké (center) and Korhogo (north) under their control for some quick cash. Several French soldiers were also accused to do the same. The above narrative suggests that the current civil war in Côte d'Ivoire is one among ethno-regional groups, it started as a civil war in which rebels aim at state dominance of some identity groups then it evolved into a civil war in which ethno-regional barons seek control over local resources. However, some analysts find this explanation of the crisis is too simplistic.

Richard Banégas and Ruth Marshall-Fratani (in Bøas and Dunn 2007: 6) agree with this argument, for they argue that this conflict is primarily political, with the local and international intertwined, generating a war about borders in which nation-states play a central role. As they comment: The case of Côte d'Ivoire illustrates how those able to 
define themselves as autochthones demand that migrants, who already have suffered resentment for quite some time, should be expelled.

Thus, the current crisis is an outcome of the unwillingness of the political elite to acknowledge that the system of governance for citizenship and land rights established under Houphouët-Boigny increasingly was becoming dysfunctional, and the principles of citizenship and rights from the Houphouët-Boigny model of patrimonial integration to the exclusiveness of an autochthonous Ivoirité discourse (Bøas and Dunn 2007: 34).

Another group of scholars have interpreted the conflict in Côte d'Ivoire as evidence of state "weakened," incapable of controlling its borders, the state finds itself faced with "ethnic leagues" and transnational rebellions recruiting mercenaries from throughout the sub-region (Bøas and Dunn 2007: 8). Other observers contend that the Ivoirian conflict was fueled above all by the search for profit and the greed of actors. For this group, "much of the rhetoric of division and ethno-nationalist hatred on both sides of the conflict is highly theatrical and a cover for ilicit economic gain.” (ICG 2004b: 2-3, Bøas and Dunn 2007: 82)

But, Banegas and Marshall-Fratani (2007: 82) do not share these interpretations. Instead they maintain that the Ivoirian conflict is eminently political. It is about who actually Ivoirian is, and who is foreigner? Or more prosaically, it is conflict over political, economic, land, educational, cultural rights, which the possession of identity papers confers, in which are opposed two distinct conceptions of citizenship, one open and the other based on the political ideology of autochthony, which carries within it the seeds of exclusion. In other words, it is a war of identification whose history is long and complex (see also Marshall-Fratani 2006). Finally, the current conflict is the indirect 
result of struggles for succession following the death of Houphouët-Boigny, beyond these recent events it is above all the latest phase of a structural crisis rooted in the colonial period (Bøas and Dunn 2007: 83).

\section{Debate Over the Causes of Civil Wars}

The debate over the causes of civil wars in Africa and other parts of the world can be listed under four broad perspectives: (1) There are civil wars which causes are related to identity group difference; (2) civil wars which causes are related to social deprivation, class conflict, and/or resource scarcity; (3) civil wars which causes are related to opportunities for economic gain for 'rebel-entrepreneurs'; and (4) civil wars that have neo-colonial causes. Each has a number of sub-themes underneath it. This structure is particularly helpful in that it makes a clear distinction between deep causes (or permissive conditions) and proximate causes, which is a goal of this study.

\section{Causes Related to Identity Group Difference}

In this perspective civil wars are viewed in general, as contests between different ethnic groups for control of the state. It is divided into four sub-themes including: (a) States with a history of inter-identity group conflict and animosities are prone to conflict; (b) States under external pressure for multiparty ("democracy"); and (c) Appearance or rise of an ethno-regional group (or other identity group).

\section{a. States With a History of Inter-Identity Group Conflict}

It is often believed that conflicts involving different identity groups in SubSaharan Africa are often created by the colonial leagcies. Such interpretation precludes that there were no precolonial ethnic warfares in Africa. Those who embrace this position 
have argued that colonial authorities had made the identities of ethnic or regional groups more rigid, planting the seeds for later conflicts.

The Rwandese case is a vivid example of this. In this case, the Belgians put the Hutu in control for decades, which backfired in the 1990s. Newbury (2002) and other scholars who worked on the Rwandese case argue that the genocide in Rwanda was partly due to the fact Belgian colonialists favored and privileged the Hutu majority over the Tutsi minority. That the granting of special identification cards to one group made the other subjects, inferior, and second-class citizens.

But, Brown (1996: 2-25) remarks that old hatred among the people has never been a powerful tool for explaining contemporary conflicts for it is hard to prove. According to him, serious scholars reject the ancient hatred theory for it cannot explain why some disputes are more violent and harder to resolve than others. He adds that the existing literature on internal conflicts does a commendable job of surveying the underlying factors or permissive conditions that make some situations particularly prone to violence, but it is weak when it comes to identifying the catalytic-the triggers or proximate causesof internal conflicts.

There has been no evidence that French colonial authorities favored and privileged an ethnic group over the others in Côte d'Ivoire. What is known, however, is that the Houphouët-Boigny family was very close to the colonial administration, thus it benefitted from this relationship. In fact, Houphouët-Boigny's aunt Yable was married to one of colonial administrator. Furthermore, it was French colonial administrator, Lieutenant Bouet, who sent the young Houphouët-Boigny to school in the first place (Houphouët-Boigny 1984). The French guaranteed him and his family certain privileges 
for their loyalty and service. He always surrounded himself with his tribesmen (the Baule) to whom he attributed the cabinet and other key posts. The current crisis in Côte d'Ivoire was not a result of ethnic manipulation by France, but the leaders themselves.

\section{b. External Pressure for Democratization from the 1990s}

During the 1990s, financial assistance to African nations and other regions of the developing world were conditioned by politico-economic liberalization, as part of the structural reforms that were needed in order to improve their economies. Unfortunately, in Sub-Saharan Africa, these IMF and World Bank structural adjustment programs resulted in a general misery a few years after their implementation. This led some scholars to quickly blame these institutions and their policy prescriptions, as the main cause of numerous conflicts on the continent in recent decades.

Democratization actually brought regime change and a big hope across the continent in Chad (1990), Liberia (1990), Ethiopia (1991), Somalia (1991), Rwanda (1994), Democratic republic of Congo (DRC) (1996), Sierra Leone (1992), and CongoBrazaville (1997), but not without human suffering, while regimes that survived this wave were shaken to their roots (Young 2002: 24). It put an end to one-party regimes in Togo, Côte d'Ivoire, Benin, and so forth. Able African leaders such as HouphouëtBoigny (Côte d'Ivoire), Mobutu (DRC), Kerekou (Benin), Eyadema (Togo), Bongo (Gabon), Biya (Cameroon) could not keep their societies under control with these strong external pressures from western powers for multipartyism.

Indeed, democratic transitions allowed the creation of a large number of new

political parties, many of which were fake parties. In some countries, members of the old system were allowed to create political parties that were actually sub-sections of the old 
ones, in order to manipulate or cheat the political process. Some African countries found themselves with close to a hundred new parties. Those parties that were not shadow were either ethnically or regionally based. Only a few had clear visions and ideologies. In Côte d'Ivoire, for example, many leaders established their legitimacy and popularity through ethnic, religious affiliations and political manipulation. But, did the expectations created by the introduction of multiparty-ism in 1990 lead to a strong sense of grievance among those who were not empowered by it?

Indeed, when the democratization wave reached all the corners of Sub-Saharan Africa, it was first seen as an opportunity for positive development. When the people realized the freedom aspect of it (weakening of the old system, and flourishing in the mass media), they started using it as a medium to voice their long time frustrations under the old regimes. In this sense, the democratization process served as an instrument to express grievances, some of which resulted to extreme violence.

Former Nigerian President Obasanjo (in Keller 1996) has argued that democratization contributed to the growing animosities in African countries. As he puts it: "An obvious cause of unease in Africa today is what is seen as an attempt by Western countries to impose Western democratic model on African countries as a condition for economic assistance from the IMF, World Bank, and other donors. Such pressure led to some of these current crises we witnessed on the continent today. He adds that, in order for democracy to be successful, it must be home grown, home induced, and home sustained. That is, the democratization of Africa must take into account the local realities, not done in a vacuum." 
Following the same line of thought, Payne and Nassar (2006: 277) argue that transition to democracy in the developing world has contributed to ethnic conflicts. These authors maintain that (in general) changes create anxieties and threaten ethnic identities. That some ethnic groups lose their privileges and advantages in a system of government that is based on impartiality, and the rule of law. Thus, many ethnic groups are reluctant to compromise and to respect different viewpoints, beliefs, and cultural practices. In the

Côte d'Ivoire case, they add, "both politicians and military rulers have proved incapable of rising above parochial concerns to take on truly national leadership. Instead they have constantly repeated past errors and flawed policies, dragging that country into a downward cycle of political instability, economic decay, and international isolation." The democratic government of president Gbagbo came to power in 2000 with a strong popular backing and high hopes for a new departure in Côte d'Ivoire politics, after nine months of military rule. The failure of democratization in Côte d'Ivoire was essentially a failure of leadership because President Gbagbo and other traditional politicians mishandled key issues, repeating past errors in pursuit of narrow sectarian, ethnic, and tribal agendas. Their incessant political infighting resulted in paralysis of government, bringing inaction, drift, and indecision. Thus, political reform in that country has caused more arms than it had done good things.

\section{c. Appearance of An Ethnic Group in Muti-Ethnic States}

This constitutes a proximate cause of civil wars only. In this case, the rebels stimulate a feeling of identity group grievance as a means of getting into power. But, who were the rebel leaders in Côte d'Ivoire, and could they have emerged under HouphouëtBoigny? Indeed, the situation in Côte d'Ivoire is a very interesting one. Under the 
Houphouët-Boigny regime, the Bete people (center-west) and Abbey people (south) attempted to rise up against the system on several occasions. The former were brutally suppressed, while the latter suffered complete isolation by the Houphouët-Boigny regime for several years.

The current rebellion consists of northerners, and Muslims from the north and northwest (generically called Dyula), and people of Yacouba and Guere descent from the mountain west. Note that the MPCI also recruited largely in Mali and Burkina Faso, some of whom speak the same language. MPIGO and MJP used similar considerations by adopting Liberians in their ranks. However, none of these groups could rise up under the first regime for reasons I explain below.

Under the one-party system, the northerners and westerners were generally kept satisfied. The Houphouët-Boigny regime offered them key positions in the cabinets, parliamentary, as well as the army, police, and gendarmerie. It also made sure that no regions were left out of the resources distribution process (e.g.: the construction of roads, regional development projects, hospitals, or the then famous indepdence celebrations in key cities). In fact, Houphouët-Boigny built presidential residences or palaces everywhere these celebrations took place during the glorious days of the economic boom. Every region was proud to host these independence festivities, and more importantly to have the president spend several the nights there.

The same tactics were used during the celebration of the Franco-African summitsHosting La Francophonie summit was regarded not only as a huge honor for the host countries, but also an opportunity to get help from the mother colony. The coming of the French president to the host state guaranteed it with a substantial aid package that is 
given in advance for the preparation of the summit, and the positive outcome of the summit reflects positively on the Head of State of that particular country.

It could be argued that the tactics adopted by the PDCI made it less likely for anyone to attack it. Had anyone tried it, he would have certainly failed because nobody was going to follow. Besides, because of the good things he had done in the past, any attempts to overthrow Houphouët-Boigny would be considered a total disrespect of the "old man." whith France on total look out this was unthinkable. The sudden appearance of the MPCI, MJP, and MPIGO on the political arena in September 2002 against the Gbagbo regime was clearly an indication of the breaching in the peaceful relationships that existed between the Houphouët-Boigny regime and the Ivoirian people, and Côte d'Ivoire and its neighbors, by the subsequent regimes.

Cultural pluralism is also important in the African context. The majority of these people are related to one another by history, origins, geography, language, and religion. While some have been able to live in such a perfect harmony, others have experienced serious 'animosities' towards each other for control of the land, resources, and power. The records of inter-ethnic rivalries have not been encouraging in Sub-Saharan Africa. Many lives have been lost in Angola, Ethiopia, Democratic Republic of Congo (DRC), Mozambique, Rwanda, Burundi, Liberia, Sierra Leone, Somalia, Sudan, and Uganda since the end of the Cold War (Brown 1996: 237). The most recent cases have occurred in Zimbabwe, Guinea-Bissau, Côte d'Ivoire, and Kenya, which nobody had anticipated, due to the relative long stability that existed there.

Multi-ethnic states are believed to be more prone to internal turmoil as different groups compete over power and other things. Wars often erupt for a variety of reasons, 
including when a society is un-integrated across class lines as in Rwanda, only strong or charismatic leaders can temporarily hold them together. In this case, the focus tends to be on a proximate causes including outside interference as in Rwanda in 1990 and CongoKinshasa in 1996, death of a charismatic leader as Houphouët-Boigny in Côte d'Ivoire; or sudden de-legitimacy of the ideology of the charismatic leader (for example, Tito in Yugoslavia, and Mobutu in Congo-Kinshasa).

For those scholars who have used multi-ethnicity to explain the outbreak of civil wars in parts of the world, and particularly Sub-Saharan Africa, the recurrent question is been whether ethnic pluralism constitutes a curse or blessing for countries that have multiple ethnicities? Some think it is, while others say it is not. The dominant view is that civil wars often erupt between identity groups that are regionally based, as in Liberia, Sierra Leone, Congo-Brazzaville, Congo-Kinshasa, Nigeria, Sudan, and Ethiopia (Adejumobi 2001, Gurr 1993 and 1994, Zartman 1996, Keller 1996, Howard 1983, and Clark 2002).

Colonialism is often blamed for the creation of multi-ethnic states in general. A good example of this in Sub-Saharan Africa is Nigeria. The formation of Nigeria was the result of the incorporation of several African nations into a single state by British colonialists. The most dominant groups are the Ibo, Yoruba, and Hausa. But, colonialism also did also divide formerly unified African nations into several states. An example of this is the old Somaliland, where the northern portion became the French Territory of the Affars and Isas (independent Djibouti), the Ogaden region annexed by Ethiopia remained a province of that country, while the southeastern portion of the Somali nation became part of the British colony of Kenya (Schraeder 2004: 49-77). If yes, ethnicity has been a 
problem in some parts of Africa, how was national unity managed in Côte d'Ivoire before and after 1993?

I have explained elwhere that Houphouet-Boigny was a charismatic leader and very skillful politician, who was respected by his peers across the continent and abroad. The young generation of African leaders came to visit him on regular basis for advice and help (Baulin 1980 and 1982). Unconditional servant of France, he benefited politically, economically, and militarily from France throughout his career. Inside Africa, Houphouët-Boigny had won the respect and trust of his people (both rural and urban), the neighboring countries loved him for his opened door policy that alleviated some of their poverty burden. Many of his major spechees toward the neighbors were inclusive, as he did the same for his people to make sure the country stayed united. Thus, he encouraged Le dialogue (dialogue) among the various groups, and la tolérance religieuse (religious tolerance) between people of different faiths. In that sense, he was a true uniter unlike his successors.

As for Bédié, many Ivoirians saw him as someone who had come to purposely destroy all Houphouët-Boigny had built since independence. Many Ivoirians think of him as arrogant and opportunist, someone who has never suffered in his life, and for whom the old president had paved the road to the presidency. In fact, Houphouët-Boigny intentionally manipulated the Constitution to ensure that Bédié becomes president when he dies. Some people have speculated that Houphouët-Boigny wanted to make sure that the Baule remain in charge of the country after him. But, Bédié was no HouphouëtBoigny. He did not have the stature and charisma that the late president had. His visions for the country were not attractive and fully developed. In fact, he had many things 
against him from the past. Besides the perception that he never worked hard enough to climb the social ladder, he celebrated his first Billions (in CFA) at the age of 27. He had also been accused of fraud in the past when he was the Head of the sugar industry. Also, many people think of him as an elitist, someone who do not speak the language of the poor and understand their concerns. Since he created the Ivoirité, to allegedly destroy Ouattara aspirations for the presidency, Bédié was seen as a divider rather than a uniter. In fact, many people blame him for starting all the troubles since 1993.

Laurent Gbagbo got his legitimacy by becoming the historic political opponent of Houphouët-Boigny, someone who vowed to speak out against the old regime, where others would not take a chance. After spending some time in jail he was forced to exile to France in the 1980s. In the 1990s, he got a strong support among University students and professors, other intellectuals, and part of the middle class. Many thought he had the right message to lead the country if given a chance. Unfortunately, a combination of factors (internal and external) moved him away from his then atractive political agenda. Like Bédié, he does not have the stature of say a Houphouët-Boigny, but has benefited from support of the Parti Socialiste Français (PSF), and he is also friend with several Heads of States including Eduardo Dos Santos of Angola, Tabo Mbeki of South Africa, and John Kuffuor of Ghana. He inherited a position that was already set on fire since 1993. That is, the atrocities and frustrations culminated under Bédié and Guéi increased the pressure on him. In fact, the civil war that occurred under his watch could have happened had Bédié or Guéï stayed in power a little longer. 


\section{Causes Related to Social Deprivation, Class Conflict, and Resource Scarcity}

The perspective examines civil wars resulting from social deprivation, class conflict, and/or resource scarcity. It says that even when wars are over ethnicities, they are really about distribution of resources. Beneath this perspective lie five distinct subthemes: (a) Civil wars arise because of maldistribution of wealth or income resulting in social deprivation, (b) rebellions often consist of people (mostly men) with no social prospects, (c) sudden mal-distribution of wealth to the upper classes or contraction of material or material resources for would-be-rebels, (d) a proximate cause of such contraction is structural adjustment programs, (e) finally another proximate cause relates to the downfall of the value of a country's main commodity crops.

\section{a. Maldistribution of Wealth or Income Resulting to Social Deprivation}

Some scholars have often linked the causes of civil wars to social deprivation, class conflict, and/or resource scarcity. Payne and Nassar (2006:276), for example, argue that competition among groups for scarce economic resources is a major cause of violent ethnic conflict. That economic development often results in unequal distribution of resources among individuals, groups, and regions within a country. Moreover, growing economic disparities may increase the fears of those ethnic groups that are disadvantaged. These authors use the Nigerian case to show how Ibo secessionists fought (1967-1969) unsuccessfully, to create a separate Biafra state because of they did not want to share their wealth from the petroleum found in their region.

Other materialists have made similar comments. Perhaps, the biggest contributor to this debate remains Paul Collier (1998, 2000, and 2002). His "Greed and Grievance" theory is one the most debated in academic circles today. Collier and his supporters 
believe that conflicts erupt when few people steal or embezzle the wealth that is supposed to provide for all the citizens. This kind of wars is been more prevalent in countries where corruption and authoritarianism have taken place, including Africa.

Bøas and Dunn (2007: 9-10) are categorically opposed to such interpretation. They insist that, rather the contemporary African guerrilla movements are the manifestations of a rage against the dysfunctional neo-patrimonial state, and provide political opportunities as well as basic survival strategies for those navigating the continuing crises of modernity. According to them, current mainstream debates often imply that all African wars are resource wars, fought not over political issues, but in order to gain access to profits. These authors charge that the so called "greed kills" arguments by scholars such as Collier (2000), Berdal and Malone (2000), and Klare (2001) have now flooded the academic circles and attracted a huge following, while elsewhere the global economy is believed to have foster the rise of so-called "new wars" theory set forth by the Klare (2001), Kaldor (2001) and Duffield (2001) alike in the Sierra Leonian and Liberian cases, for example. That scholars such as Keen (2005: 25), for example, has argued that in some African conflicts, the goal of some actors is not necessarily the defeat of the enemy in battle but the continuation of fighting and the institutionalization of violence for profit. They claim this interpretation often mistakenly assumes that the predations are the reasons for the guerrillas struggle.

Bøas and Dunn (2007: 11) maintain that the "greed kills" thesis explain why these incentives have come to play such an important part in recent wars: that is, the economic agenda research assumes the profit motive on the part of the belligerents, but it fails to explore why or to what extent political-military actors become profit-seeking, market- 
based entities. In order to understand this transformation, one needs to take into consideration political, cultural, and historical factors in addition to the economic dimensions of conflicts. Berdal (2003 and 2005), for example, later recognized that the "greed" thesis focuses excessively on material explanations and greed-inspired motivations of factors, which may lead to one-sided explanations of conflicts.

\section{b. Rebels As People Without Other Social Prospects}

Ted Gurr is one the leaders of this theory. Gurr and the other have suggested that the rebel armies consist of persons (mostly males), with no other social prospects, or urban unemployed, implying that if jobs were available, those who are rebels would take the gainful employment instead. But, Bøas and Dunn (2007: 1) warn against the dominance of what they call "greed-based approaches," which some scholars have used to explain the true nature of African conflicts. For these authors, treating African guerrillas as devoid of any kind of political agenda, greed-based approaches present them as bandits. That such an interpretation significantly narrows the number of possible policy interventions. As they puts it : "You can negotiate with armed rebels with a political agenda, but bandits are to be crushed by force...Much of the recent literature on insurgencies has mistakenly focused on single-factor explanations, such as greed, resources, and culture.” (3-4).

One helpful way to explain African insurgencies is to examine various motivations including: ideology, grievances against the central government, regional and social marginalization, elite desires to capture state power, the crisis of the post-colonial state, and the extreme politicizing of autochthony debates. It should include an examination of the external context of insurgency groups, the end of Cold War, global 
"war on terror," as well as important changes in international and regional markets, which in turn will promote an understanding of African insurgency movement as both creations and responses to the crisis of modernity and its dysfunctional institutions in Sub-Saharan Africa (Bøas and Dunn 2007: 5).

In his conceptualization of youth movements in Africa, Morten Bøas (in the same volume) writes that Africa is a continent of youth, and those who fight are mostly young men. However, young African fighters are often depicted as ruthless murderers or powerless victims. He notes that, both views oversimplify by failing to account for the nature of war. That the only way to understand youth involvement in such processes is to take their experiences seriously, even if the narrative presented by such youthful dramas does not fit well with existing categories for understanding political behavior.

Abdullah (1998: 204) has also received mounting criticism from Bøas and Dunn (2007) regarding his work that focuses on the socially marginalized youth, to understand the origin and character of the RUF in Sierra Leone. Abdullah regards the "revolution" of the RUF as a product of a rebellious youth culture in search of a 'radical alternative' to the regime of the All People's Congress (APC). He pays attention to lumpingunemployed and unemployable youths (mostly males) whom he regards as being "prone to criminal behavior, petty thefts, drugs, drunkenness and gross indiscipline."

For Bøas and Dunn (2007: 7), Abdullah's explanation fails to establish a causal connection between lumping social status and their supposedly inherent violent behavior, answer some obvious questions such as: why do some youth opt the 'brush path to destruction' and others do not? What role does gender play, given that most youth opting for violent alternative are males? What political factors are involved in shaping these 
youth cultures and sub-cultures? Is this situation really just a "wanton use of violence for the sake of violence" or more complex dynamics at work? (13)

The rebel rebellion in Côte d'Ivoire consisted of persons of different backgrounds, men outnumbered women soldiers. The MPCI had a sizeable number of women from the north, while MJP and MPIGO soldiers appeared to be all males. Moreover, the soldiers were made up of former professional soldiers who deserted their posts or were previously fired, rural and urban youths without jobs, professionals of the public and private sectors, University and High School students, and foreign mercenaries. The Côte d'Ivoire case shows that the explanation by Abdullah (1998) and others does not always apply to all African cases. Rather, it confirms the arguments advanced by Bøas and Dunn (2007) and others, which I can subscribe to for the purpose of this study.

\section{c. Sudden Redistribution of Wealth to the Upper Classes}

Some materialists emphasize the sudden redistribution of wealth to the upper classes or contraction of material resources for would-be rebels. For instance, if the lives

of peasants or urban workers are relatively good under one political economy regime, and then their lives suddenly get worse under a subsequent regime, they will become disgruntled, and join a rebellion. Such case is very rare in Sub-Saharan Africa.

Indeed, it is natural and normal that human beings react when their physical security and financial wellbeing is threatened. Based on this assumption alone, the people who join rebellions may have valid reasons to do so. But, did the subsequent regimes withdraw sources of economic sustenance previously available to workers and peasants in the Côte d'Ivoire case? 
There was no evidence of such thing in the country. As I have mentioned elsewhere, the situation in that country since 1993 is a political one, that is, it gravitates mainly around succession matters. That is, it started as electoral issues and spread beyond electoral issues. The Bédié regime was preoccupied with succession matters so that it did not have the time to accumulate wealth. Also, there was no evidence of such thing under the military junta led by Guéi. One thing that was clear, however, was that the economy plummeted during those years, and many peasants fell neglected or forgotten by the various regimes. This was not done intentionally to affect a specific groups, it was more a natural consequence of what the country had experienced in those years. Therefore, it is safe to argue that the situation in Côte d'Ivoire is not one that concerned the redistribution of the country's wealth.

\section{d. Structural Adjustment Programs}

One proximate cause of the contraction of material resources for the would-berebels is believed to be the structural adjustment programs imposed by the World Bank and International Monetary Fund. These adjustments were supposed to generate some revenue, help states repay part of their debt, and improve the lives of the people, but they did not yield the expected results. Instead, they have brought more misery, including wars over political reform. In fact, most contemporary Africanists and Third World scholars have forcefully argued that the sudden "belt-tightening" that goes along with the conditions of a structural adjustment program generates a sense of social betrayal and hardship, leading to civil war.

Between 1972 and 1992, Africa experienced a weak economic performance due to some internal and external factors, though the level of performance was country- 
specific. While few countries have been able to control the crisis, many have experienced serious trouble going from excessive borrowing, unability to pay the workers, or provide basic services for the populations. The root causes of these economic and social crises that led to the adjustment policies have been the subject of ongoing debate in political and academic circles.

Today, the debate has shifted from examining the root causes of SAPs to looking at the impacts of IMF's interventions in these economies. On the one hand, the neoconservatives argue that structural adjustment is not only necessary and unavoidable, but the only viable alternative for survival in a changed global economic environment. On the other hand, neo-Keynesians criticize the manner in which the IMF' SAPs are designed and implemented. These scholars maintain that the IMF's macroeconomic prescriptions accentuate the impact of the crisis on the poorest and most vulnerable sections of society, forcing the government to cut social welfare and government workforce. The victims were the weak, poor, and those without a job.

In Africa, the impact on the agriculture sector is a major one for various reasons and especially for those countries that rely heavily on agricultural products for exports (roughly $85 \%$ of Africa's populations rely on the agricultural sector). Critics have also argued that the IMF's reforms had adversely affected the agricultural sector, and the impacts are country-specific. For example, in Zimbabwe, tax and pricing reforms under adjustment have brought windfall gains for commercial farmers, but relatively modest improvements for smallholders. In Zambia, Tanzania, and Mozambique, most poor producers were excluded from profitable trading by lack of land, credit facilities, and 
marketing infrastructure. Instead, the beneficiaries have been monopolistic private sectortraders, who are well placed to exploit the poorest producers and most marginal areas.

In the Sahel region, the liberalization of agricultural sector has had adverse consequences for many of the poorest producers. Since the poor are concentrated in rural areas, the impacts of adjustment on poverty is still determined by what happens to rural smallholders and rural self-employed outside the agriculture, where welfare is linked closely with the performance of, and incentive structure in agriculture. Generally speaking, SAPs have not been friends of the farmers in the Global South. These farmers have been negatively impacted, which have dramatically changed their living conditions and habits. The problems faced by the African farmers include lack of foreign investment, access to land, and credit.

But, should the IMF and World Bank be blamed entirely for this failure? A quick answer is: not really. Scholars such as Nicholas van de Walle believe that it would be wrong to ascribe the worsening poverty in many developing countries entirely to World Bank-IMF policies. These scholars point to such things as the inappropriate forms of state intervention, corruption, excessive military spending, and an adverse external trading and financial environment, have played a role in undermining human welfare.

Van de Walle (2001), who has written extensively on this issue, claims that African states have plenty of autonomy, and therefore they do not have to answer to their own populations. Furthermore, African states are also autonomous vis-à-vis the International Financial Institutions (IFIs), they do not have to accept these conditionalities. But, African countries do get aid. He is convinced that these states have not really implemented the structural adjustment programs in full. Van de Walle's 
argument implies that African leaders have pretended to implement SAPs, but have not really tried hard enough. They have gone slowly with privatization as matter of fact. They have done it out of the desire to control the desire to maintain political control. This author also suggests that the aid African countries have gotten is in fact too much, not too little. That the aid they have received has corrupted them, and made them unaccountable to their people. As a result, they remain detached from their people, and do not need to extract much revenue from them. Van de walle (2001) also rejects the theory that SAPs are bad, and do not work. He insists that the partial and differential implementation of such programs is the real source of rapid economic contraction for the impoverished of African countries. Hence, the blame should not be entirely on these institutions, but on the local leaders.

But, did any of these structural adjustment programs increase economic hardship in the 1990s in Côte d'Ivoire, leading up to the war? Moise Koumoue (1994: 5-7), a former Minister of Economy and Finance (1989-1990) under Houphouët-Boigny, and who was personally involved in the process notes the following:

In 1990, the measures of stabilization in the financial sector resulted in massive strikes and other social protests, forcing the government to renounce its first plans to reduce workers' salaries ( $3 / 4$ of the total budget). At the same time, the government put an emphasis on structural reforms in order to improve the budget. It can be said that the expected results were achieved in 1992, when 9 billion CFA Francs were generated, by improving the fiscal surplus and lowering government expenditures by 16.7 billions...At the social level, the effects of the crisis and the reform in the public and private sectors led to the contraction of the job market... The Gross national product (GNP) shrank by $3 \%$ in 1990 , and $1 \%$ in 1991 , about $4.5 \%$ on average per capita annually from 1989-1991. The persistence of the situation made the politics of adjustment more difficult...On 31 July1992, a joint communique from the Heads of States of the CFA Franc zone, decided to maintain the parity that existed between the CFA Franc and the French Franc (FF), reinforce their internal structural adjustment programs, as well as regional cooperation. As a consequence, the principal instrument to the adjustment remained the budget, therefore the necessity of finding a new internal formula for adjustment in Côte d'Ivoire. 
Hence, an objective examination of Côte d'Ivoire's economic and financial crisis in 1989 led to the creation of a program that would cover the entire period of 1989-1996, a stabilization phase (1989-1990) to reduce public expenditures and increase savings (1991-1993), and stimulate growth (1994-1996) (Koumoue 1994: 9-11). In order to succeed, the people had to make the necessary sacrifices to save the country from plunging further. When the first attempt of SAPs did not yield the expected results, President Houphouët-Boigny then called upon Allasane Ouatara, a former IMF deputyDirector for Africa, to rescue the declining economy. Later, Ouattara became the country's first Prime Minister. He designed some important, but painful measures that resulted in massive protests across the country.

In 1994, when the CFA franc was devalued, more people became poorer, unable to provide for their families, or send their children to school. The government succeeded in adjusting the areas that were less likely to meet social protests. Poverty became even more pronounced among the people in the subsequent regimes. Because the crisis economic crisis started in the late 1980s, one must argue with caution that whether this has played a major role in the uprising of September 2002 in Côte d'Ivoire.

\section{e. Sudden Downturn in the Relative Value of a Country's Main Commodities}

Various scenarios can cause a sudden downturn of commodity prices including:

the commodities lost their importance or value on the world market, the buyers found a substitution for them, or are effectively produced by other countries.

Côte d'Ivoire relies heavily on cocoa and coffee. Up to the mid-1980s, this country was the world largest producer of cocoa (800,000 tons in 186/87), and it occupied a high rank for coffee (210,000 tons in 1989/90) in Africa (Koumoue 1994: 18). 
As I stated elsewhere, cocoa and coffee production brought a huge number of migrant workers from the Sahel region including: Burkina Faso, Niger, Mali, and Guinea. Within Côte d'Ivoire itself, the cocoa and coffee belt formally located in the center and southeast regions attracted many people from other regions, and from nearly states. As time went on, the rapid depletion of the forest area compounded with a high demand for cocoa and coffee plantations caused many people to move to dense rainforests of the western region. Unfortunately, the prices of these products fell dramatically in the 1980s and beyond. According to Koumoue (1994: 18), the prices of cocoa, which was already low in 1987, continued to decline following the fluctuation of the dollar and increase in the world production. By 1990, the price of coffee also declined sharply due to the crisis on the world market. In 1986, the price of coffee reached catastrophic levels. After 1991, the prices of cocoa and coffee dropped to record low, because of the high stocks of on the world markets. The economy of Côte d'Ivoire plummeted further and has not recovered since.

As a result of this, the Ivoirian farmers (including cocoa and coffee growers) who account for nearly $80 \%$ of the population became bankrupt, unable to take care of their families as they used to. Their hopes were again dashed when the economic recovery plans imposed by the IMF and World Bank did not work to their benefit. The lives of the Ivoirian farmers have deteriorated significantly since 1986 on. The numbers of the unemployed, universities and technical schools graduates was a record high, while the youths remained hopeless. These young men and women now engage in all sorts of criminal activities in order to survive. The general misery has created lots of discomfort among the people. Those in power and their associates live abundant and flashy 
lifestyles, while the poor people continue to struggle to survival on daily basis. It is not clear whether the downfall of the price of the main commodities have played a role in the uprising against the Gbagbo regime in September 2002. Though, their effects were felt across the board for the country was hit very hard.

\section{Causes Related to Economic Gain for "Rebel-Entrepreneurs"}

The argument here is that civil wars started by those who wanted to seize part of the country and exploit resources or seize control of the state. There are several competing explanations of this.

Hirshleifer (1995 and 2001), for example, argues that the possible causes of conflict relate to the notion of preferences, opportunities, and perceptions. He writes that proxies for opportunities have three common sources including: extortion of natural resources, donations from diaspora, and subventions from hostile governments. In their part, Sachs and Warner (2000) believe that the causes of civil wars include poor public service provision, corruption, and economic mismanagement.

Paul Collier is a leader of this theory. His great works on the subject command tremendous respect and this has won a name for himself. To be sure, Collier $(1998,1999$, 2000, 2001, and 2002) has recently made the powerful claim that civil wars result from the desire of rebel group leaders to get control over natural resources or commodity products, including processed commodities, cocaine in Colombia, for example. That the permissive conditions for such wars include: International market for commodities (coffee, cocaine, opium, diamond), and sufficient state decline for the rebels to seize control over commodities with impunity. As proximate causes, they are the emergence of rebel groups that armed themselves and feed themselves through the sale of commodities, 
and/or a sudden rise in the price or scarcity of the commodity in question. Indeed, many recent civil wars around the world seem to be linked to such causes: For example, the Colombian cocaine rebels in Latin America, Sierra Leonean blood diamonds in West Africa, Afghan opium Talibans in Asia.

In Côte d'Ivoire these could be called the cocoa and coffee cowboys. Noted that these economic entrepreneurs often couch their appeals in materialist terms, that is, they claim to be fighting for social justice (like Colombian rebels) when their real aims are simply to seize power and enrich themselves. But, have the rebels in Côte d'Ivoire sought to control cocoa and coffee in order to enrich themselves and sustain the rebellion? Have they abandoned other, putative motivations for going to war?

As I mentioned elsewhere, the FN's initial motivations were to remove President Gbagbo from power. These hopes were dashed during the early hours of the uprising when the loyal forces to the Gbagbo regime succeeded in pushing them back to the center, and northern regions of the country, where they had settled permanently. Foreign troops were put on the ground to prevent both sides from clashing any further.

When it became clear that the rebels would not go to Abidjan, they then turned to the exploitation of the natural resources under their control. They engaged in the illegal exploitation of cocoa, coffee in the west, and diamond in the northwest, near Seguela. The revenues generated served to enrich themselves, and to sustain their movements. Some local newspapers have reported that some rebel leaders have built villas, hotels, and shops in neighboring countries Guinea, Mali, and Burkina Faso. Also, during the first hours, the rebels broke into many banks under their control and stole undisclosed amount of cash. 


\section{Neo-Colonial Causes}

The main argument is that developing countries become unstable, and the conditions for civil war are created, by the withdrawal of support by a former colonizer, or previous great power external patrons (especially United States or former Soviet Union). But that this is a proximate cause only. In this perspective the causes of Africa's numerous conflicts are divided into two main categories: the permissive conditions and proximate causes. In the first category, Africa's internal conflicts are believed to have roots that extend to various conditions present at independence. One of them is that colonial powers established borders that corresponded little to African political, cultural, and economic life (Brown 1996: 328).

Furthermore, the first generation of African leaders, or the "Pères de la Nation," accepted colonization borders rather than entering into the arduous and politically volatile process of redrawing them. In fact, the Charter of the Organization of African Unity (OAU), now African Union (AU), places great emphasis on the permanence of existing borders and principle of territorial integrity (Brown 1996: 240). In the second category, two factors contributed to Africa's wave of political instability in the late 1980. The IMF and World Bank structural adjustment programs jeopardized the neo-patrimonial state. However, some countries were still benefiting from superpowers patronage (Brown 1996: 243).

For Young (2002), the roots of Africa's violence lie principally with political and economic conditions that existed after independence, and the policies pursued by elites to gain and consolidate power. He writes that, commons patterns of state and class formation in Africa have led to endemic, intense internal conflict. Even Southern Africa, 
where wars of independence and majority rule continued into the 1990s, violence was exacerbated by conditions inherited from colonialism and the policy choices of new leaders. The recent changes in international policies have affected the state, namely the new global economic, political, social, and cultural transformation may have an impact on the stability of African states, and may even combine to serve as a primary cause of major political unrest.

Francis Deng (in Rupesinghe 1996) also stresses the effects of the colonial heritage on post-colonial African states. He argues that because of the way in which African states were created and people were separated, the states are now confronted with a crisis of nation building. That, the ethnically highly heterogeneous states are now challenged by competition for state power and national resources, often escalating to crisis and armed conflicts (in which the legitimacy of the state and the controlling authorities falls into question). Deng argues that politicians and military rulers have proved incapable of rising above, what he calls "parochial concerns," to take on truly national leadership. Instead, they have constantly repeated past errors and flawed policies, resulting in a downward cycle of political instability, economic decay, and international isolation.

Stedman (in Brown 1996: 236) makes similar comments that Africa's recent internal conflicts have arisen from long-term permissive conditions and more immediate proximate causes. According to this author, legacies from colonialism predisposed much of Africa to violent conflicts over the distribution of resources in societies, access to political power, and basic political identities. Using Nigeria as an example, he notes that colonialism created both class conflict and multi-ethnic states. Such legacies help create a 
pattern of state and class formation in which African political leaders relied on external support to reward internal allies, and ignored the needs of their citizens.

In the Côte d'Ivoire case, it should be noted that, in the past, Houphouët-Boigny offered and guaranteed almost the entire Ivoirian market to French corporations. After his election in 1995, Bédié tried unsuccessfully to change that. He was victim of a military coup four years later. Also, the Gbagbo regime had a strong resentment via-à-vis French economic dominance in Côte d'Ivoire before it took power. Mamadou Koulibaly, an influential member of the regime, co-wrote a book in which he explains why the French dislike the Gbagbo regime. If yes, this is true, one can say that French is committed to protecting its interests in Africa at all costs, including Côte d'Ivoire. An argument could be made that France stimulated the civil war because Gbagbo threatened (somehow) its interests in Côte d'Ivoire.

The present chapter has also provided different taxonomies of the different kinds of civil wars. Based on these typologies, the civil war in Côte d'Ivoire is one that is among the country's various ethno-regional groups. A discussion of the Ivoirian civil war shows that it first started as a category 2-war (civil wars against the state) then it moved to a category-4 war (civil wars against over the local resources). The various explanations suggest that the war in that country is complex, but overall, it is a war that eminently political. The Annual Review of Sociology (1994: 14) argues forcefully:

There remain some serious difficulties to overcome. Repeated observations over time are needed for the dynamic analysis that could begin to disentangle causal sequences. In spite of numerous controversies and confusing empirical findings, the same basic conditions for ethnic conflict repeatedly are identified in the works here reviewed, most important are: Strong ethnic identies/boundaries' grievances, opportunity structures; resource mobilization. Any research that seeks explanations should attend to all these simultaneously. 


\section{CHAPTER 3}

\section{DOMESTIC AND INTERNATIONAL POLITICAL ECONOMY}

Chapter three is about the domestic and international political economy as a source of civil war in Côte d'Ivoire. It seeks to examine the correlation between the civil war and people's income levels, to see the trend after President Gbagbo came to power in 2000. Morever, it looks at the effects of the various structural adjustment programs, and falling prices of Côte'Ivoire's main commodities (cocoa and coffee). In other words, did socio-economic grievances stimulate the fighting? Finally, it examines the attitude adopted by the rebels towards the resources under their control after the civil war broke out, to determine whether this was a part of their initial plan, or it was a pure coincidence?

\section{A. Background On the Ivoirian Economy}

Although Côte d'Ivoire has important natural resources deposits (petroleum, natural gas, diamond, manganese, iron ore, cobalt, bauxite, copper, and hydropower), it relies heavily on agricultural products such as yam, cocoyam, manioc, rice, banana plantain, maize, peanut, millet, and palm oil, for subsistence, and cocoa, coffee, rubber, citrus, palm oil, cotton, tobacco, pineapple, and recently cashew, for cash crops. These two types of crops, and especially the latter, generated an impressive economic growth between 1960 and the mid-1980s (Kouadio and Gottlieb 1997). The production of export commodities such as coffee and cocoa imposed by the French colonial administration, and a comparatively high level of industrialization, attracted foreign interests into Côte d'Ivoire in the first place (Amir 1967, Nyong'oro 1987, and Cohen 1974). 
Significant components of the Ivoirian population remain divided by occupation. While a small fraction of the population serve as civil servants at all the levels of government, agriculture constitutes by far the most important occupation for the majority of the people. For instance, Akan farmers (in the center and East) mostly cultivate cocoa, coffee, rice, pineapple, bananas, and rubber. As for Senufo farmers (in the north), they specialize in rice, sugarcane, millet, mangoes, and cotton; some northern communities are pastoralists also. Bete and Dida farmers (in the west) also grow rice, coffee, and cocoa, while other farmers in the country tend to have small plots growing a variety of the above crops.

As for the commercial sector, it is controlled by Dyula and Malinké traders, with men dominating large-scale trade and women prominent in small-scale trade, while the transportation has been led predominantly by Dyula as well as Kulango, Baule, Agni, and Bete men. Meanwhile, forestry has largely been left to Lebanese, European businessmen, and some local elite. In fact, the logging industry in Côte d'Ivoire started with French colonialism in the 1900s. The savage exploitation of the country's rainforest continued even after independence, which resulted in a huge deforestation due to excessive and illegal logging, and loss of the beautiful fauna present in the region (Kouadio and Gottlieb 1997).

Other immigrant populations control specific sectors of the economy as well. For example, the Ghanaians dominate the fishing industry, while the Europeans control the shipping industry. The French companies particularly own important share in the energy, water, and telecommunication sectors. The Lebanese are in the restaurant and importedgoods shops business. As for the Nigerians they owned food and household good shops, 
while Senegalese and Moroccan own imported technologies and clothing shops. A combination of all these activities made Côte d'Ivoire an economic success in the early years of independence.

From the start, Côte d'Ivoire's economy was shaped in such a way that it was difficult to shift from one sector of production to the other. Although some people have been able to switch career, in general, each group have been able to hold on tight to their primary occupation until recently. Indeed, the initial division of labor has significantly been changed in recent decades, due to the high unemployment rate, retirement from a previous job, massive layoffs, businesses closures, overpopulation, unregulated immigration, growing informal sector, and migration from-and-to urban centers. The informal sector has become the domain of the young people and women. The lack of decentralization of state institutions, and the civil war of September 2002 have made the situation worse. Abidjan, the capital city, is now polluted and overpopulated.

According to former Budget Minister Moise Koumoue (1994: 15), in 1994, 44\% of the people of Côte d'Ivoire lived in urban centers, 56\% lived in the rural areas, $70 \%$ attained schools, 6 million people were active, $43 \%$ were less than 15 years old, while life expectancy averaged 52 years. The agricultural sector occupied a good place in the country's economy, with $30 \%$ of the gross domestic product (GDP), and $80 \%$ of state revenues came from exports. The growing of cocoa and coffee (the main commodities for exports) covered approximately 2.5 millions acres, with some 400,000 workers who supplied direct and indirect jobs (1994: 17).

Between 1985 and 1986, this country had experienced a huge growth in the cocoa sector with 800,000 tons in 1994. However, the price of cocoa fell in 1987 on. As for 
coffee which was estimated to 210,000 tons between 1989 and 1990, fell due primarily to aging plants. The situation was worse in 1991 for the price of both commodities. As for the rubber production, it augmented to 60,000 tons since 1987 until 1988, and was 130,000 tons in 2000, although the price fell in 1984 and 1987. As for cotton production, it was estimated to 300,000 tons, while pineapple and banana productions dropped to 160,000 tons each since 1988, palm oil reached 902 tons in 1986-1987, but fell to 785 tons, and sugar was 150,000 tons between 1989 and 1990. Timber production also fell, as forest protection became a major concern on the world stage. The government also sought to industrialize the mining (gold, diamond, iron, nickel) and industrial sectors until 1970. However, in 1981, the government was forced to perform its first structural adjustment program as a result of the economic crisis (Koumoue 1994: 18-24).

Because of the rapid depletion of the rainforest that resulted from excessive and illegal logging, and the traditional ways of farming (mostly slash-and-burn), many Baule farmers from the center moved into the deep rainforests of the west in search for better lands to grow cocoa, coffee, or both. As a result of this, the western region experienced a significant increase in population resulting in serious environmental stress. The settlement also created land disputes and resources scarcity in the region. In the 1990s, there were multiple clashes over land tenure and ownership involving the locals and alien populations. Some of these confrontations resulted in many deaths, which made headlines in the local and international news media.

Chaleard (2000: 54) who has carefully documented, and examined some of these clashes in the western region writes that these tensions were fueled, in part, by what he calls "the blockage of the plantation economic system, and lack of sound policies by state 
leaders." He argues that the readjustment following the huge forest loss since 1980 created tensions between various ethnic groups (locals and foreigners), some of which had opposed the Baule to Burkinabè, Bete to Burkinabè, and Bete to Baule. Chaleard (2000:54) also remarks that the change in leadership in the government since 1994 is a reflection of the alliances made around the concept of Ivoirité created by President Bédié, which privileged nationals over foreign migrant workers.

Chaleard describes how these foreigners were stripped their rights to vote since 1994, an anti-immigrant laws regarding land tenure was voted in 1998. It occasioned xenophobic acts against foreigners, especially from Burkina-Faso, Mali, and Niger. Many foreign farmers were expelled from their lands in the southwest region in November 1999. The expulsion also included Ivoirians from the north (also called Dyula).

Akindes (2004: 8-9) takes the discussion back to the colonial era. He argues that, President Houphouët-Boigny inherited a colonial policy from France that favored vigorous agricultural development, this coupled with a high concentration of foreign capital, led Côte d'Ivoire to becoming a sub-regional economic pole that attracted other factors of production including: sub-regional labor, capital, and a variety of expertise. For instance, labor migration from Togo, Mali, Burkina Faso, Niger, and Benin increased significantly as a result of this economic euphoria of the 1970s and 1980s. The coastal region with $3,733,413$ inhabitants, of whom 622,372 were international migrants, offered more opportunities for employment and self-employment than elsewhere. Furthermore, the economic crises in Ghana and Nigeria in 1970 and 1980 caused part of this migration 
toward Côte d'Ivoire. To be sure, the 1998 census estimated the total population of the country to $15,366,672$ inhabitants, $26.03 \%$ of whom were immigrants.

However, it should be stated that immigration alone does not cause tensions when it is well regulated. On the other hand, an uncontrolled immigration can be a source of tensions between the local and immigrant populations. In fact, immigration becomes an issue, and this is true for all societies, during tough times and economic crises. Under these conditions, the immigrants are often seen as invadors, thus the source of a country's trouble.

In Côte d'Ivoire, these tensions were created because of lack of regulation of the land tenure system by the Ivoirian government, and absence of legally binding documents between initial landowners and their buyers at the time of the various deals or transactions. In fact, one of my closest relative who had been involved in these types of deals once told me that, in some cases, some people had bought their land or sold it verbally to others, which turned out to be the recipe for conflicts later on. He also added that, in some instances, the landowner sought to retake the land now in full production capacity from the original buyer under fallacious grounds, either to sell it to someone else for more profit, or use it for their personal gain. Some people viewed them as xenophobic and tribalism toward certain groups. It was in this context that the western region of Côte d'Ivoire had experienced several confrontations and atrocities between the local and alien populations, resulting in many deaths, injuries, loss of livelihood, and ethnic tensions, and even hatred. Unfortunately, the leaders exploited the situation for personal gain. 
In order to spare their own lives and those of their family members, some alien farming communities had abandoned their cocoa and coffee plantations altogether, and returned to their native regions or countries, thus loosing all their assets they had so tirelessly worked for for years. That and other factors had ultimately contributed to the misery of the Ivoirian people in general, and the farmers in particular. But, did these socio-economic related issues stimulate the war in any ways?

To answer this central question, I have divided and outlined the period of the economic boom, followed by the period of economic decline to see the implications. I have designed a number of empirical questions that need a close examination. For instance, did the population of Côte d'Ivoire become poorer? Were the people uncertain about the future? Did the size of the middle class shrink? Was there a decline in the socio-economic indicators of the people? If the population got poorer in the 1990s, what effect did this have on civil violence? Also, what resources did the rebels go after and how they have used them to support themselves? Or how did their military and political strategies change as the situation progresses?

\section{Period of Economic Growth (1960-1980)}

Indeed, Côte d'Ivoire's impressive economic take-off after independence in 1960 was followed by an economic downturn that made it very vulnerable toward the end of the 1980s. Many observers have structured the eras of economic boom and economic downfall in that country with a minor difference. Of the many works produced on this subject, Akindes (2000: 126) has proposed a more comprehensive structure. He has

divided the short economic history of Côte d'Ivoire into two main periods. He calls the 
first period the growth period (also called economic miracle), and the second period the period of uncertainty (also called economic mirage). He writes that, on the macroeconomic scale, Côte d'Ivoire experienced eighteen years of steady economic growth (1960-1978) followed by twenty years of uncertainties (1979-1999).

President Houphouët-Boigny engineered this success never stopped bragging about it. In fact, he did so many times when he was given the opportunity during his puclic appearances. Below is one statement he had made in the past (my own translation):

At independence in 1960, we had two options available to us. The first option, was the immediate africanization of the workforce, replacing foreign nationals with Ivorians, this was the easiest option. The second option, and the most difficult, was to train leaders capable of gradually replacing those expatriates who were in positions of high responsibility. It was the second option that we chose, because Côte d'Ivoire did not want unqualified leaders. We did not want an africanization for the sick of doing so. Therefore, we chose a legitimate africanization that included young ministers and graduates from highly reputed institutions (Koumoue 1994: 33).

Houphouët-Boigny made the above statement during a meeting with the international business community. The president used this medium to defend his economic policies, and vision for Côte d'Ivoire. He had made similar statements in several of his public speeches, including party conventions, national conferences, as well as annual addresses to the nation. Not only he personally took pride of the good reputaion this country enjoyed at that time, but also he wanted to show that he was in fact the main artisan of the relative economic success that country. Houphouët-Boigny and Côte d'Ivoire became a success story both economically and politically in Africa and the developing world from 1960 until the mid-1980s. As a result, this country was highly respected worldwide, especially by the former colonial power, France. 
The Ivoirian success was the result of a number of factors including: open-door economic policies that focused primarily on the agricultural sector, along with relatively high levels of industrialization, as well as a model of an "African democracy" that emphasized regional and ethnic inclusion in the management of the affairs of the state.

According to Akindes (2000), the period between 1960 and 1980 constituted the era of economic growth or economic boom in Côte d'Ivoire. The so-called 'Ivoirian economic miracle' was characterized by the availability of finances, important investments, and in general the importance of public spending. That the success was also based on a combination of an opened policy to the outside that consisted of recruiting foreign workers, capital and expertise, and a liberal economy based on the exportation of coffee, cocoa, and timber (see also Amir 1967, Nyong'oro 1987, and Cohen 1974). This period was remarkable for investments by the government in sanitary supplies, multiplication of infrastructures in the education sector, or training in engineering schools, creation of public enterprises, political granting of government scholarships and recruitment of University graduates to gradually replace foreign expatriates, political clientelism, free access to public education, formation, and healthcare.

However, Akindes (2000: 127) remarks, this distribution of the fruits of economic growth were unequal across communities and regions. The populations of the forest zones were the biggest beneficiaries of this, due to the exploitation of timbers and cocoa and coffee, as opposed to the people from the center and north. The government had tried to fix this unbalance by creating several sugar factories in the north, the opening of the port of San Pedro (southwest), and the creation of a hydroelectric dam in Kossou (center). Abidjan, the economic capital, became the symbol of the politico-economic success, far 
ahead of other towns and cities, where people, especially the elites showed luxurious lifestyles, and the political class introduced in the business world. The middle class showed some signs of these lifestyles also. The external signs of this wealth in Abidjan influenced the people in the sub-regions who migrated to Côte d'Ivoire in great numbers in search for better opportunities (2000: 128)

It should be noted that the first two decades of independence had for principal objectives a strong industrial growth, which was characterized by two phases. Until 1975, the industrialization relied on foreigners, namely French-at the end of the 1970s. New public industrial enterprises were put in placed. During those years, the Ivoirians (both public and private) accounted for $1.4 \%$ of the industrial sector, and $6.6 \%$ of foreigners who were non-French. The enterprises had a social capital of $92 \%, 90.6 \%$ of investments, $94.1 \%$ of value added, and $93.8 \%$ of the workers, of which $97.5 \%$ were expatriates (Chevasu 2001: 10-11).

The strategy of large openness to foreign capital and investments in the industrial sectors stimulated growth respectively from $22 \%$ to $23 \%$ per year between 1961 and 1971. But, the politics of welcoming foreign investors cost lots of money. Thus, the number of foreign workers had to be reduced by educating young Ivoirians, who did not shine in the sciences $(4.7 \%$ in the industrial sectors in $1971,90 \%$ of direction personnel, $86 \%$ for cadres, and 49\% for Agents de Maitrise high salaries), other Africans in the factories accounted for 38\%, (Chevasu 2001: 12). Finally, in 1975 and 1977, the prices of Côte d'Ivoire's products rose significantly (for coffee and cocoa), due to the effects of freezes in Brazil, drought in Colombia, the war in Angola, stagnation of the production in other African competitors, and some Asian countries that were starting industrialization 
process (14). An analysis of the industrial sector of Côte d'Ivoire in 1995 showed a reduction of the productivity since 1977 .

After this impressive economic growth, the Ivoirian economy began to fall apart in the 1980s, because of an unprecedented economic crisis that resulted in inexcessive foreign borrowing and a huge national debt. The crisis impacted the public and private sectors, as well as the different segments of the Ivoirian society. The so-called economic miracle had now turned to what Akindes and others have called economic mirage, explained next.

\section{Period of Economic Downfall (1981-1990)}

At the beginning of the 1980s, Côte d'Ivoire's economy started to experience some serious problems. The causes of these troubles were both internal and external. According to Toungara (1990: 37-38), from 1960 to 1989, cocoa registered a ten-fold increase passing from 80,000 to nearly 800,00 tons, and coffee output more than doubled to 300,000 tons, placing Côte d'Ivoire among the world's top producers. The loss of an extended struggle against unusually low prices for Côte d'Ivoire's main agricultural exports (cocoa and coffee), resulted in a drastic cut of $50 \%$ in the price of kilo paid to peasants, hence a drop from 400 to 200 CFA for cocoa, and from 200 to 100 CFA for coffee in the $1988-89$ seasons. In 1989, the public debt was estimated at 14,000 million USD, the highest per capita in Africa.

Toungara writes also that during the period between 1981 and 1993, poverty rose significantly. The economy plunged in a deep recession that reached its picked in 1987. As a result of this, the government, which was unable to service its foreign debt, decided to suspend its payment. It then adopted a structural adjustment programs in which it tried 
to cut government spending under tremendous pressures from the International Financial Institutions (IFIs), namely the IMF and World Bank.

Unfortunately, these adjustments did not yield the expected results, and things became worse. Then, the need for the third phase came: The devaluation of the CFA Franc, through the infamous structural Adjustment programs imposed by these Bretton Woods Institutions (Akindes 2000: 128-129). The next section discusses these structural adjustment programs imposed on Côte d'Ivoire, and their effects on the people. It also looks at the trend of the country's main commodities (cocoa and coffee) prices on the world market up to 2002 .

\section{B. Structural Adjustment Programs}

I have mentioned earlier that the period between 1960 and 1980 was marked by significant economic and developmental progress that led some analysts to describe Côte d'Ivoire (perhaps too quickly) as an exception in Sub-Saharan Africa. Among these observers were Amin 1970, Cohen 1974, Hecht 1983, and Nyong’o 1978 and 1987, Chevasu 2001, Toungara 1990, Akindes 2000. According to these scholars, Côte d'Ivoire, not only was regarded as the mirror of Western and Francophone Africa, but also a symbol and model of political and economic success on the continent and the developing world. Politically, President Houphouët-Boigny was considered the main architect of that success and stability due to the fact that he was able to hold the various ethnic and religious communities together (Chabal 1993, and Rothchild et al. 1996). Economically, he created an African capitalist model for his country that generated a huge success in the first two decades of independence, as well as massive West African immigrant communities into Côte d'Ivoire. A large number of people of Lebanese 
descent, French, and North Africans settled in Côte d'Ivoire also (Nyong'oro 1978 and 1987).

As Rothchild et al. (1996) write, the president believed in a unified, stable, and modern state built on a solid base of agricultural export, which was translated by an opendoor policy throughout the region, which attracted foreign migrant workers in the cocoa and coffee plantations owned first by the local planters (Baulin1980). Gradually, some of these migrant workers were able to purchase some portion of the land and grow their own cocoa and coffee, and thus some of them settled permanently. Thus, Côte d'Ivoire became the world largest producer of cocoa, and occupied a high rank in coffee production as well (Hecht 1983; Nyong'o 1987, Amin 1970, den Tuinder 1978, and Brayton 1979).

Unfortunately, the relative economic prosperity of the early years of independence could not be sustained, because of a number of internal and external forces. The country desparately needed political reform and economic change (Toungara 1986), for the so-called 'economic miracle' was now being tarnished (Bourke, 1987), and the ideology of development in place was heavily been challenged (World Bank 1987, Akindes 2004, Young 1982, and Rapley 1993). Between 1980 and 1990, the fall of the price of cocoa and coffee occasioned a fatal downfall of Côte d'Ivoire's economy.

The official newspaper, Fraternite Matin (2003), reported that all the sectors of the economy were hardly hit, especially the agricultural sector. As a result, many people could no longer afford to send their children to school, and buy basic goods, including medicine. Moreover, the habits and lifestyles of the people changed drastically creating anger, frustration, and general misery among the majority the population. Expectedly, 
this had put enormous pressure on the government both internally and externally. Inside the country, the number of the discontents grew rampant, while in outside there was a pressure from the foreign debtors, including the International Monetary Fund (IMF) and World Bank. On 25 May 1987, the government announced it could no longer pay its external debt, which was estimated at 6 billion U.S.D., forcing it to accept and implement some painful policy prescriptions (also known as structural adjustment programs) imposed by the foreign donors led by the IMF and World Bank.

Bratton and Van de Walle (1997) explain that these structural adjustments programs (SAPs) consisted of two phases. The first phase (also called stabilization phase) aimed at injecting some cash into the system to keep it running. The second phase (also called reform phase) consisted of reforming the economic and financial sectors, which in turn would stimulate growth. The expectations behind these adjustments were that part of the revenue generated would serve to repay the country's foreign debt, and ensure the financial security of the people.

Hence, in 1989, the World Bank and IMF required that the national economy be made competitive by depreciating the exchange rate and improving the public finances, resulting in a significant increase in unemployment, which was already high due to the closing of many factories. Moreover, the government proposed to reduce the salaries of the workers in the same year. Knowing the fact that in Sub-Saharan Africa the government is the major employer, and also that one civil servant feeds more than his or her own nuclear family (husband, wife, and children) it was clear that cutting the salaries would have dramatic consequences on the population as whole. Expectedly, these measures provoked huge social protests in Abidjan and elsewhere in the country, forcing 
the government to review its first round of adjustment measures. It tried without success to find new ways that would be less painful. Each time it met the opposition of the people.

It was in this context that president called upon Allasane Dramane Ouattara (also called ADO), a former Governor of the West African Central Bank in Dakar (BCEAO), who was serving as Deputy-Director of the African Division at the International Monetary Fund in Washington D.C., to inject some shocks into the Ivoirian economy (Konate 2004). In April 1990, Ouattara led the Comité Interministériel de Coordination du Programme de Stabilization et de Rélance Economique to oversee the adjustment program. On 7 November 1990, he was named prime minister, the first in Côte d'Ivoire's history. However, the honeymoon between the new prime minister and the people did not last long. Ouattara designed a number of necessary, but unpopular measures that is to follow.

The first set of measures included: reduce the number of government vehicles per ministry, force the wealthy barons of the old regime and private sector to pay back taxes accumulated over the years (especially in telephone, water, electricity, and other personal properties), suppress the gratuity of University buses that used to be free for all the students, and privatize both government owned and semi-owned companies (Faternite Matin 2003).

It should be reminded that the round of the austerity measures implemented by Mr. Ouattara did not reach the expected results for the government's coffer remained empty. Each time Ouattara decided to add new measures he met mounting social unrest 
throughout Côte d'Ivoire. The end result was the takeover of the airport by army conscripts in 1990.

Akindes (2000) and Kieffer (2000) have carefully documented this military, while Cogneau (2003: 87), Toungara (1999: 23), and others have extensively written on the social implications of these adjustments in the country. These authors see these protests as a direct response to the appalling and poor economic diet imposed on the country by the IMF and the World Bank. Côte d'Ivoire, like many African states and the developing world, had badly failed its first structural adjustment programs test with the International Monetary Fund and World Bank.

For a while, Ouattara and his drastic measures became the center of all the daily conversations throughout the country, especially in Abidjan. Those barons who were summoned to pay back taxes disliked him so much. In the end, these structural adjustment measures, which were intended to improve the economy in the first place, brought more misery to Côte d'Ivoire and its people. President Houphouêt-Boigny's death on 7 December 1993 opened the door for another phase of adjustment, the devaluation of the CFA Franc by 50\%, which was tied to the former French Franc (FF).

Some analysts have argued that had he been alive, Houphouët-Boigny would have stopped this devaluation. In fact, the president had always opposed that the CFA be devalued when he was still alive. The devaluation of the CFA Franc on 10 January 1994 was part of the global structural adjustment programs that were set up by the International Monetary Fund (IMF) in the developing world including Côte d'Ivoire, in order to help these countries improve their economic status, and the living standards of their citizens. Also, more adjustments took place in the industrial sectors. As Chevasu (2001: 
10-11) notes, despite the risks, some French investors such as Groupe Bolloré in the shipping industry, the buyout of the SOGB (rubber plantation) privatized in 1995 of $20 \%$ of CIDT (Textile) in 1998. The first company to transform cocoa and coffee, SACO increased its capacity by 10,000 tons in 1996 . Note that French companies were important and present in Côte d'Ivoire. Some had been there long before independence in 1960 (for example, CFAO and AXA). Of the most recent ones, Bouygues, through SAUR remains the main shareholder for the Compagnie Ivoirienne d'Electricité (or CIE), CIPREL (for electricity production), and Société des Eaux de la Côte d'Ivoire (or SODECI) for water.

French banks and their branches dominate the financial market: The Société Générale de Bank en Côte d'Ivoire (SGBCI) for the Société Générale, Société Ivoirienne de Banque (SIB) for Crédit Lyonais, Banque Ivoirienne Pour le Commerce et Industrie de Côte d'Ivoire (BICICI) for Banque Nationale de Paris (PNB). The Group Bolloré is also active in the transportation sector via SAGA, SDV and SITARAIL. It is also a tobacco producer thanks to SITAB. Other groups are also present and continue to contribute significantly in the infrastructure industry (SETAO and COLAS, Bouygue, and Jean Lefebre), while Total and Elf possesses 25\% of the oil refinery, Société Ivoirienne de Rafinage (SIR).

According to the same report, at the end of 1997, the stock of French direct investment in Côte d'Ivoire was 22\% of all it had in the Franc zone (with Gabon and Congo on top because of huge investment in oil). Investment rose from $52 \%$ between 1995 and 1997, to reach 226 billion FCA Franc, while investment in the Franc zone diminished (2001: 25). In 1997, France Télécom bought 51\% of Côte d’Ivoire-Télécom. 
Public enterprises were privatized because they were loosing, which has a negative impact on the state budget. Bernard Contamin found that in the case of CIE, there were $50 \%$ of unpaid bills before privatization took place, now the unpaid bills amount to 55 after privatization.

Meanwhile, a development strategy called Eléphant d'Afrique (African Elephant), which was created under the Bédié regime projected that in the years 2015-2025, a newly industrial country will be born in Africa (a more vibrant private sector must be created) (Chevasu 2001: 23). Until 1998, the results of this new politics were remarkable (with $2 \%$ growth in 1994, 7\% annual growth until 1998. It helped reduce the budget deficit significantly, which moved from $11.9 \%$ of GDP in 1993 to $6.5 \%$ in 1994 , it fell to $1.8 \%$ in 1998 (Cabrillac 2000). The growth was supported by the production of coffee and cocoa which price augmented on the world market, pushing growers to intensify production. But, the commodity prices fell again in 1999.

The manufacturing and construction also rose for about $10 \%$ per year. The manufacturing sector moved from $20.5 \%$ in 1993 to $24.6 \%$ in 1998 . This was the result of a return of foreign investments, which rose from $7.8 \%$ of GDP in 1989 , to $16.6 \%$ of GDP in 1998. Foreign investors contributed to this re-establishment in the economic and financial sectors (Chevasu 2001: 24). Despite this improvement at the governmental levels, there were no clear signs of improvement in people's lives. Their pockets remained empty. That is, at the same time these adjustments were happening the population was getting poorer and poorer. The next section discusses the difficulties face by the Ivoirian people. 


\section{Effects of Structural Adjustment Programs}

A 2003 GRIP report suggests that, between 1970 and 1979, Côte d'Ivoire witnessed an annual growth rate of $6.7 \%$. But, it was in the early 1990 s that the first signs of weakness became apparent. In 1990, the Houphouêt-Boigny regime collapsed following the Franco-African summit of La Baule, the structural adjustment programs imposed by International Financial Institutions (IFIs) prevented Côte d'Ivoire's economy to benefit from the international markets. The Ivoirian economy was hard hit, with 50\% devaluation in 1994 of it's the CFA Franc, which impoverished a large portion of the population. The social conditions were negatively impacted, and tensions rose between the various communities (GRIP 2003: 7).

According to same report, Côte d'Ivoire was expected to be the major beneficiary of the devaluation, due to the increase in its commodities prices (coffee and cocoa) from $1.5 \%$ in 1994 to $6.5 \%$ in 1996 , to reach $5.75 \%$ in 1999 . The effort to manage the inflation rate (starting at $32.2 \%$ in 1994 , fell to $7.7 \%$ in 1995 ) had no serious impact on the people for the period following the devaluation contributed to the deterioration of the living standards of the households. As public services such as gas, electricity, and transport were increasing, the price of basic products such as cereals, vegetables, and others experienced an increase (Akindes 2000: 129).

Akindes notes that in fact these early good results of the devaluation hide the social inequalities and other social indicators. As he writes, in reality, poverty rose from $10 \%$ in 1985 to $32.3 \%$ in 1993 , then $36.8 \%$ to in 1995 . Urban populations witnessed higher levels of poverty especially households who relied on the informal sector were hardly hit. These inequalities could be seen at the national scale also. To be sure, in 1993, 
1995,1998 , the national ratio of poverty were respectively $31.3 \%, 35.4 \%$ and $33.4 \%$ for households headed by an Ivoirian, and 35.4\%, 44.7\%, and 34.3\% for households headed by a foreigner. Between 1994 and 1996, the various police brutalities increased with the instauration of the Identification Card for foreign nationals, which resulted in massive return in the neighboring countries (for instance, Mali, Guinea-Conakry, Burkina Faso, and Niger), especially those who were illegal and poor. These brutalities reduced the number of poor among foreigners in 1995 (Akindes 2000: 129).

The period 1981 to1990 was the period when the negative effects were more severe. For instance, in both the urban and rural areas, the health services were unable to cover the needs of the people, where there was a lack of equipments and medicine, resulting in many deaths in the hospitals people. As for the schools, they had no supplies, the number of people wanted to go to school surpassed that of facilities available. Classes were overcrowded along with low quality of the education system.

In his part, Chevasu (2001: 10-11) argues that the problems started to become perceptible in the economy at the end of the 1990s as a result of state debt, the low purchasing power of the population, of which the GDP was only 455, 000 CFA (734 USD) per capita, and high social inequalities that impeded social consumption. The household consumption fell from $74.2 \%$ of GDP in 1993 to $58.1 \%$ in 1998 . The state encouraged foreign investment in order to create employment and salaries. The factors related to the bad distribution of household revenue created serious health and education problems. A World Bank report in 1997 shows a lack of good education and social services. The same report revealed that $37 \%$ of Ivoirians lived with less than $12,000 \mathrm{CFA}$ Franc (19.7 USD) per month (Chevasu 2001: 24). 
Before the outbreak of the civil war in September 2002, the people from Abidjan were already facing economic hardships, $44 \%$ of households were living with difficulties $35 \%$ said they were using their savings, while $43 \%$ said their resources were unstable. Only $7 \%$ of the people said were living well, and only $2 \%$ could save. Poverty among the people living in Abidjan rose significantly. A survey conducted during the first semester of 2001 and the first semester of 2002 indicated that $2 / 3$ of the household thought their general economic conditions were deteriorating, while $5 \%$ said it was not (that is largely negative -62 points). Only $1 / 10$ household said their purchasing power was improving. On the job market, since the period 1996-1998 (dates of available surveys), the unemployment rate became stable while the salaries remained high, due to high education attainment (Roubaud 2003: 60-61).

It is safe to argue that the effects of the crises of the 1980 s and early 1990 s resulted in a major fall in the living standards of the Ivoirian population. The consumption of the people fell by $50 \%$ on average between $1985-1993$, according to a report by the Institut National des Statistiques (INS), by 75,000 CFA Franc per year (1.5 USD/day per person), which moved from $10 \%$ to $31.3 \%$. The same report reveals that half of the poor people were concentrated in the savannah zone of the north in 1985 , however, the fall of the cocoa and coffee prices had a negative impact on the forest zone as well. Poverty rose significantly in the secondary cities and towns as well, from $8 \%$ to $31.2 \%$. In 1993, Abidjan was the last region to be protected by extreme poverty with 5\% of poor people. During the period 1994-1998, the living standards rose by $2.5 \%$. Only the western region showed a significant reduction of poverty level from $38 \%$ to $24 \%$. It doubled in Abidjan (11\%). On the national scale, the inequalities increased significantly 
in Abidjan (from 0,49 to 0,53) as in the rural areas (from 0,42 to 0,49), but it remained stable in other urban centers (Cogneau and Mesple-Somps 2003: 98).

In 1995, unemployment rose to 17\%; PIB was 9.4 billion USD in 2000, 9.2 billion USD in 2001, growth rate was -2.3 in 000 and +0.1 in 2001 ; foreign debt was 15.8 billion USD (GRIP 2003: 8). The poverty level rose by $16 \%$ between 1985 and 1988. In 1997, the World Bank admitted that $37 \%$ of Ivoirians were living with lower that 12,000 CFA (less than \$20). The urban employed of government and private sectors were the first victims of the structural adjustment programs (Campbell 2000: 146-151).

GRIP (2003) writes that in 1998, the numbers of non-military public workers were reduced by $4 \%$ and the average salaries fell by $28 \%$ for civil servants. It was expected that household utilities bills (mainly electricity and water) would go down in 1985-1993. Instead, they had gone up between 1993 and 1998 both in rural and urban areas. Meanwhile, malnutrition rose between 1985 and 1993, while in 1994 and 1998 HIV/AIDS became very preoccupant in the country (GRIP 2003: 99). Between 1993 and 1998, the urban poor and average poor were most impacted by the crisis. Poverty among the employed deepended in Abidjan, and by five in other urban centers (100)

According to Campbell (2000: 149), when he took power, General Guéï told foreign debtors the coffers were empty. At first, he vowed to suspend any debts incurred by his predecessors. However, this decision was revised on 13 January 1999, so that he can pay the army personnel and government workers. In 1998, the foreign debt of Côte d'Ivoire was estimated to 14.7 billions USD. The unpaid bills by the Bédié regime amounted to nearly 1 billion USD (584 billion CFA) between 1998 and 1999. The IMF 
estimated that 1999 would see a deficit of 197 billion FCA (322 billion USD). An indepth audit showed that the dues culminated to 7\% of GDP were about 500 billion CFA. It was hoped that in 2000 the country was to take care of its foreign debt estimated to 756.8 billion CFA. However, the International Financial Institutions already suspended their help for the democratic process ended with the military junta, compounded with bad management, and massive fraud by the Bédié regime. Below is a table the Human Development Index of the country for 2002 provided by United Nation Development Programme (UNDP).

Table 4: Human Development Indicators (2002)

\begin{tabular}{|l|c|}
\hline \multicolumn{1}{|c|}{ INDICATORS } & STATISTICAL DATA \\
\hline Poverty Rank in the World & 79 \\
\hline Life Expectancy at birth in 2002 & 41.2 Years \\
\hline $\begin{array}{l}\text { Population below \$1 a day 1990-2002 } \\
\text { Population below \$2 a day 1990-2002 }\end{array}$ & $15.5 \%$ \\
\hline $\begin{array}{l}\text { Population below the national poverty line in 1990- } \\
\text { 2002 }\end{array}$ & $50.4 \%$ \\
\hline GDP in 2002 & $36.8 \%$ \\
\hline GDP Per Capita in 2002 & 11.7 billion USD \\
\hline
\end{tabular}

Source: UNDP Statistics (2002)-Côte d'Ivoire

A close reading of the above United Nations Development Programme (UNDP) statistical report on Human Development Index (HDI) also confirms this. These data also paint the same grim picture that scholars and researchers have explicitly highlighted. The table indicates that in 2002, life expectancy in Côte d'Ivoire was among the lowest on the continent (41.2 years). Although this could be attributed to poverty, it should be noted 
that Côte d'Ivoire was also among the African countries that were severely impacted by HIV/AIDS, which reduced the life expectancy significantly. According to the same UNDP statistics, between 1990 and 2002, 15.5\% of the people lived under \$1 USD a day, while 50.4\% lived under $\$ 2$ a day. The people who lived under the national poverty line accounted for 36.8\%, while the gross domestic product (GDP) was only \$707 in 2002. The table also shows a fluctuation in the Human Development Index between 1975 and 2002. Côte d'Ivoire was rank 79 in 2002 among the world countries based on these figures. The above observations suggest that there is a large consensus among scholars and researchers that the situation in Côte d'Ivoire was a dire one. The population was suffering terribly from the economic recession, now coupled by these structural adjustment programs imposed by the international debtors. But how did the people of Côte d'Ivoire cope with these socio-economic problems? The answer follows.

\section{Coping With the Crisis and Effects of the Adjustments}

In every society there is a natural tendency to create coping mechanisms during difficult times at the individual, community, and state levels. In Sub-Saharan Africa, the first two levels take precedent over the latter for the state is quasi-poor, and unable to help. Moreover, in that part of the world, sociological and anthropological findings suggest that the group is more important than the individual. Not only this traditional way helps retain a strong sense of identity, but also reinforce the social, political, ethnic, religious, and regional solidarity, and loyalty among the people.

Indeed, when the crisis became apparent, and the consequences well assessed, many Ivoirians began to create coping mechanisms to support one another. According to Akindes (2000: 129-130) the gravity of the crisis led many Ivoirians to adopt important 
coping mechanisms. Among others things, the creation of traditional structures of solidarity that served as social security for the severely impacted, as they were unable to respond to the needs of the people who used them. That the deepening of the crisis also changed the relations between the people and communities, the consequences of which were the weakening of the traditional social relations, and the emergence or the reinforcing of structures of intermediations, namely the many competing religious sects or denominations who specialized in the healing of these problems and hope providers. The author adds that the inability of the state to provide for everyone widened the itinerary of exclusion (unemployment, declassification, and marginalization), which became an itinerary of refusal, characterized by the prosecution of the state, accused of injustice and corruption. Gradually, the masses became a critic in the opposition parties.

The devaluation following the CFA Franc caused an increase in the household food budget, the slow increase in the salaries (from 10 to $20 \%$ ) failing to cope with inflation. There was an increase across the household budgets of the various social layers, causing the suppression of such things as meat, fish, and fat products (Akindes 2000: 126). Another strategy was to modify the structures of expenses on things like entertainment, clothing, social expenses, and consumption of industrial drinks. These households limited all to necessary, or vital needs. For example, people started to seek the help of traditional healers, traditional medicine, and second hand clothes (131).

In order to feed themselves some poor households used both legal and illegal means to generate funds, for example, multi-activities, child-labor in the informal sector. Corruption in the public administration sectors increased rapidly. Some households made 
up of friends, neighbors, co-workers, or religious fellows in Abidjan organized themselves in associations or buying groups to reduce the costs of basic food necessities (rice, meat, chicken, frozen fish). Finally, those with savings specialized in real estate, to improve their buying power (132).

As for members of the middle class, they made relations with wealthy women to benefit from their assets and revenues to save their own households. Several analysts of social standards in Côte d'Ivoire showed two phenomena: the importance of women in the urban and household economies, due to the weakening of men due to salary crisis. Men never thought of doing certain jobs believed to be dishonoring or dirty (for instance, gate keeper or vigil, garbage collector, low skilled factory worker, and small vendor) which was performed traditionally by non-Ivoirians (especially from Burkina-Faso and Mali, and Niger) now done by high school students (Akindes 2000: 133-135). In the rural areas, many young people migrated from the poor regions of the center and north towards the southwest agricultural zone where competition was already high on land tenure (Akindes 2000: 135; see also Charleard 2000).

Côte d'Ivoire experiences with these adjustments were not good in the sense that they did not benefit the people who got poorer across the board. The state did benefit somewhow but this was short lived, perhaps because these adjustments were never fully implemented in the first place. It could be argue that the SAPs have been responsible for a major increase in poverty -for reasons now well documented summarized as follows: huge national debt leaving no money for infrastructure programs in education, health, jobs, etc...--and hence an increase in general misery of average and poor people, thus higher general dissatisfaction (Kouadio and Gottlieb 1997). 
The economic crisis in Côte d'Ivoire's was the result of the fall of its main commodities prices, low confidence of the International Financial Institutions (IFIs) following a massive embezzlement of funds given by the European Economic Community, fear of foreign investors because of the unstable and uncertain political, fear of the old regimes to be held accountable for their acts, that they might be punished for complicated things further (Akindes 2004: 28). The only option left President Gbagbo was to change the behaviors and mentalities in Côte d'Ivoire, if he wanted to reduce poverty, re-establish confidence, and restart the economy with a competitive industrial sector. He tried, but his attempt was short-lived.

In sum, Côte d'Ivoire experienced its first round of structural adjustment program in 1981. But it was not until 1994 that these SAPs became really known to the general public. In the 1990s, SAPs became popular for a variety of reasons including: their direct effects on the general public, devaluation of the CFA that made everything expensive, the appointment of Allasane Dramane Ouatara to oversee and manage that process, the various measures undertaken by him, and of course the political problems that ensued after he became interested in the highest office in the country.

It could be argued that despite all the bad impacts this had on the people and the country as a whole, the SAPs as a process did not play a significant role in the crisis per say, perhaps, the fact that it has revolved around the person of Ouattara. The crisis in Côte d'Ivoire did not only hit the northerners and western communities who are now fighting against the Gbagbo regime, this may have played only a role as a root cause, not a proximate one that actually triggered the war in September 2002. 


\section{Rebels' Attitude Toward the Local Resources}

I have mentioned elsewhere in this dissertation that when the civil war broke out the rebels occupied the north and part of the west, after they failed to topple the Gbagbo regime. I also mentioned that the initial motivation of the rebels was to remove Gbagbo from power, as they claimed. These hopes were dashed during the early hours of the uprising when the loyal forces to the Gbagbo regime succeeded in pushing them back to the center and northern regions of the country. Thus, they settled permanently. Therefore the war moved from a category-two (against the state) to a category four-war (war of occupation). MJP and MPIGO fighters who later joined the MPCI also claimed that their only ambition was to avenge their Yacuba brother, Guéi,, who was killed during the night of 19 September 2002. The New Forces (FN), as they finally called themselves, failed to advance toward the economic capital, for foreign troops were already on the ground to prevent both sides from clashing again.

When it became clear that the rebel fighters would not go to Abidjan, they then turned to exploiting the natural resources and commodities under their control. Thus, they engaged in the illegal exploitation of cocoa and coffee in the west, as wellm as diamond and gold in the northwest, near Seguela. The revenues generated alledgly were used to sustain their movements, and also for personal gain. In fact, several local newspapers have reported that some rebel leaders, among whom Sherif Ousmane and Kone Zakaria, have exploited these resources to build villas, hotels, and shops in neighboring countries including Guinea-Conakry, Mali, and Burkina Faso.

Also, during the first hours, the rebels broke into a couple regional central banks under their control and stole undisclosed amounts of cash. The evidence from other wars 
shows that when rebellions fail their initial plan, they often turn to alternatives ones. In this case, the war became a war of occupation. Their action, it could be argued, was more of a coincidence than anything, for they thought they could do the overthrow Gbagbo in less than a week. The next chapter discusses the role of ethnicity and region as identity of the war. 


\section{CHAPTER 4}

\section{ETHNICITY AND REGION AS IDENTITIES IN THE WAR}

Chapter four discusses the role of ethnicity and region as identities in the civil war that broke out in Côte d'Ivoire in September 2002. It seeks to explain how have ethnoregional differences shaped the current civil war in that country, and whether they are a root or proximate cause of that war? The chapter has been organized in a straightforward fashion. First, it discusses how the various ethno-regional groups in Côte d'Ivoire were able to live together in such harmony from 1960 up to 1993 ? What stimulated the previously quiescent ethno-political forces to take up arms against each other? Second, the chapter examines the ethno-regional composition of the competing military forces on the ground, namely the national armed forces (FANCI) and rebel groups (FN), and seeks to understand whether the superficial appearance of the war between different ethnoregional forces is wrong, or it is more complicated than it seems.

The current section examines the relative unity that existed under President Houphouët-Boigny in Côte d'Ivoire from 1960 until he died in 1993, and explains how the subsequent regimes failed to maintain this precious unity. In order to have a good understanding of what went wrong in that country, it is important that the situation be put in historical context. It should be understood from the start that President HouphouëtBoigny ruled this country for nearly four decades under the one-party state system. During that period, every Ivoirian national was de facto perceived a member of the Democratic Party of Côte d'Ivoire (PDCI), although there was some limited opposition on the ground, which operated in the shadows. The single party system drew a large 
following for reasons that I have explained in the introductory chapter. And it continued throughout the presidence's tenure.

In 1990, the political landscape in Côte d'Ivoire was dramatically altered with the advent or installation of multiparty-ism. The new dynamic not only marked the end of an era in that country, but also opened the doors to new behaviors, habits, and culture. Most importantly, it brought more competition, participation, and hope for freedom among the people. It should be noted that Côte d'Ivoire's politics has been much influenced by its physical environment, ethno-sociology, and cultures. Because of these complexities it is important that to examine its physical geography, history of settlement, socio-

ethnography, as well as history of the relationships that has existed between the people, to have a full understand of the current situation on the ground.

\section{A. Unity Under Houphouët-Boigny (1960-1993)}

Several factors, including socio-cultural, political, and economic, can explain the initial relative success that Côte d'Ivoire has had in achieving unity among its heterogeneous population between 1960 and 1993. The first set of factors relate to the president himself. Houphouët-Boigny was a charismatic leader, wise man, tactical and career politician, who held positions in various French governments prior to Côte d'Ivoire's independence in August 1960. Appointed traditional Chief of his tribe (the Akwe), he was able to navigate sharply between traditional ways of ruling and conduct modern politics. Very respected at home and abroad, Houphouët-Boigny was also a source of inspiration and consultation for many other leaders around the world, especially the young generations of African leaders (for example, Thomas Sankara, Jerry Rawlings, Samora Machel, and Charles Taylor). 
The second set of factors has to do with the economic and development vision Houphouët-Boigny had for his country. For example, he wanted to build a successful modern state that could compete in the world economy. Moreover, he created a national political identity that further united the people, and boosted their confidence. He achieved numerous personal and national goals, aided by his close ties with the traditional leaders, and their integration in the decision-making process across the nation. Thus, he understood the importance of ethnicity and culture in national development, rewards in the agricultural sector, other traditional activities, resources distribution, firm control of the political machine, opened door foreign policy, urbanization, religious tolerance, national and regional geopolitics, education and civism, law and order, presidential pardons, and national dialogue were the cornerstone of his political agenda. A major concern of the government after independence was to foster interaction not only among the locals, but also locals and foreigners (Kouadio and Gottlieb 1997).

Michael Cohen has dedicated a large portion of his graduate work to explain how and why President Houphouët-Boigny was able to consolidate unity of his country, and develop successful economic policies for nearly four decades. According to him, after independence the towns of Côte d'Ivoire were assigned specific roles within the national strategy for economy development. As a result, secondary towns have developed along routes to Abidjan, particularly after the construction of the Abidjan-Ouagadougou railroad line at the beginning of the century. Transportation, processing, and marketing of agricultural products have created waged employment, which has attracted streams of migrants from country villages to towns of the south. Urbanization of the country has led to increasing contact between the sixty different tribes within its boundaries. Naturally, 
increasing interethnic contact has led to a nascent national culture (Cohen 1974: 21-22). While the interaction between Ivoirian nationals and foreign Africans witnessed some friction (often resulting in sporadic violence), the country has, nevertheless, become dependent on foreign participation in the economy. The multi-ethnic and multinational character of the economic life is also evident in the political process of the country (Cohen 1974: 22).

In the political arena the early PDCI members consisted of a broad coalition of both Ivoirian ethnic groups and representatives of foreigners living in the country. The organization of the PDCI reflected this multi-ethnic membership, which individual ethnic committee (comites ethniques) linked to sub-sections (sous-sections), which were themselves represented in the national council (conseil national), the directing committee (comite directeur), and the political bureau (bureau politique). These structures operated on the principle of 'democratic centralism', with decisions communicated unanimously to higher levels (Cohen 1974: 23).

In the agricultural sector, the Ivoirian development strategy was based on the productivity of cash crop to support a modern urban industrial sector (Côte d'Ivoire was among the most industrialized on the continent in the early 1960s-1980s). This strategy requires cheap agricultural labor to maximize agricultural earnings and trained manpower to operate and manage the technology of industrial growth (Cohen 1974: 24). Such consideration urged the president to open the doors to new regional migrant workers, especially from the neighboring countries. These regional laborers not only were considered regional brothers, but also ethnic and religious brothers. Note also that Guinea-Conakry, Mali, and Burkina Faso made up the former French Sudan, which Côte 
d'Ivoire was a part. Their contribution was positively felt and desirable during the first decades of independence until the price of the major products (cocoa and coffee) started to fall in the 1980s on the world market.

On the one hand, critics have warned that dependence on foreign labor and capital could eventually lead to economic stagnation, and subject the country to external forces over which it may have little control. Côte d'Ivoire had experienced just that, since the economic crisis of the 1980 s and on. On the other hand, admirers of the Ivoirian approach have pointed to the failures of African countries like Ghana (quick economic downfall) with limited foreign investment that sought economic independence immediately after self-government in the 1970s.

Meanwhile, the mal-distribution of income and concentration of wealth in Abidjan had deepened the disparity in the level of economic well being among the regions of the country. Tremendous differences between the wealthy south, clustered around Abidjan, and the impoverished north raise the issue of balanced national development. National development plans have continually emphasized the problem of regional disparities, yet from a few highly publicized efforts, such as the rotating annual national independence celebration, the Kossou (center-west) hydroelectric dam, or the San Pedro project in the southwest. There has been little consistent distribution of resources to areas outside of the economic capital city, Abidjan (Cohen 1974: 27).

The distribution of rewards was evident during the first regime to ensure individual or group loyalty. Urban resources of all kinds, including electricity, water, housing, schools, markets, maternity clinics, and administrative facilities, were all tied to 
ethnicity and support for the government. The failure to express sufficient militancy for the PDCI and the government led to neglect, as this was the case of the town Agboville (south) throughout the 1960s. On the other hand, support for the government or one of its key figures was rewarded with the granting of public resources. Thus, in 1962, when former Minister of Construction and Town-Planning Kacou Aoulou had to choose one hundreds villages to receive urban improvements, he received a list of localities from Philippe Yace (then president of the National Assembly and PDCI secretary-general). It was an effort by the president and the PDCI to reward loyal populations and encourage support from oppositions (Cohen 1974: 90)

It should be added that even with a neo-patrimonial system in place the distribution of rewards was not equitable. The Houphouët-Boigny regime continued these selective, discriminatory, and conditioned policies until 1990, which had sporadically sparked protests among the people, especially in the urban centers. Government response to urban protests was largely successful for the first decades of independence. Although occasional opposition to specific policies developed throughout the same period, the administration was able to either co-opt it by the politically profitable distribution of urban resources or to suppress it by closing off the nonviolent means of expression. By the end of the 1960s, however, opposition became increasingly evident, and on occasion, violent. The military was used to put down street actions or student strikes-it did show that opposition did exist within the one-party state, outside the party (Cohen 1974: 95).

These protests were ethnic or regional in character. A good example of this was the 1970s rebellion of the Bete people in the Gagnoa region (west) following the death of 
Kragbe Gnagbe, an early political activist and ethnic brother, that led to thousands deaths for entire villages were massacred by the military, and the Abbey people of Agboville (center), who were also on the government black list after one their ethnic brother, Biaka Boda (political prisoner), was allegedly killed by the Houphouët-Boigny regime. However, the Houphouët-Boigny regime had carefully crafted a strategy to fight these oppositions that proved successful between 1960 and 1993.

The Houphouët-Boigny regime's response to ethnic mobilization was a unique institution officially known as le Dialogue (the Dialogue). Consisting of a series of mass meetings between President Houphouët-Boigny and all the "Couche Sociales de la Nation (national social groups), the dialogue emerged as an effective means of political communication (Cohen 1974: 115). There were many examples of this.

In February 1963, after the creation of a court of state security to investigate an alleged plot against the government 1,000 people gathered at the palace in support of the President. After a second plot was uncovered in September 1963, both the government and party organized a huge rally of some 100,000 people at the Houphouët-Boigny stadium in the capital city, Abidjan, during which speakers from all the regions, ethnic groups, and professions expressed their adherence to the government and the president. Public officials promised new policy measures for political support (Cohen 1974: 116)

On 22 September 1969, at a meeting of the bureau politique of the PDCI, President Houphouët-Boigny proposed meeting all the couches sociales (social groups) of the country, including teachers, students, students parents union (UNAPEECI), the executive committee of the workers union (Union Générale des Travailleurs de Côte d'Ivoire) or (UGTCI), the bureaus all the unions, employers, Lebanese community, 
tenants, construction workers, transporters, pharmacists, doctors, bookstore owners, and sports clubs. The schedule would end with a meeting of the bureau politique, which would examine the issues discussed in the dialogue (Cohen 1974: 120).

Expectedly, the president's choice reflected careful ethnic criteria. He appointed a popular and respected Bete from Daloa (west), Jean Lorougnon Guede, as Minister of Education, leading Agni from Aboisso (southeast), Joseph Tadjo Ehue, as Minister of Civil Service, Edmond Bouazo, another Bete from Issia (west), and Albert Vanie-Bi Tra, a Gouro from Zuenoula (center-west) all of whom represented the politically important forest peoples.

The coastal lagunaire groups were also included in the persons of Grah Kadji, from Jacqueville (southeast), Hypolite Aye from Anoumanbo (south), and Etienne Ahin from Bingerville (south). The youth of the new ministers as well as their ethnic identities satisfied possible criticisms from the students, Bete, and the Agni of Aboisso who were vicious critics of the President (Cohen 1974: 148). The above discussion clearly suggests that the crafting of the responses to mass protests was carefully planned by the Houohouet-Boigny regime. While individuals may seem unimportant, therefore easy to control, the ethnicity or regions were given much attention. The following three strategies speak to this effect.

The first aspect of this strategy_reconciliation with former political opponents was an ideological one. Throughout 1970 the former political leaders who had been purged during the plots of 1962-64 gradually received public attention. The first of these men, Charles Donwahi (a Bete from the west), received land in 1969. As for Germain 
Coffi Gadeau (a Baoule from the center), he received a concession definitive (garanteed house) in Treicheville, Abidjan (Cohen 1974: 174).

The second strategy Houphouët-Boigny used to gain electoral and political support was the demonstration of respect for traditional chiefs across the country. For example, in April 1970, Philippe Yace was made the spiritual Chief of the Alladians, a tribe living along the Ebrie Lagoon. In a well-attended ceremony at Jacqueville, Yace performed traditional rites indicating his respect for his elders. In August of the same year, Yace attended the Fete de Generation (generations celebration) at Debrimou (south), a clan near Abidjan, and donated 100,000 CFA francs to the age group in the name of the PDCI and the government (Fraternité Matin, 24 April 1970: 4).

The third aspect of the electoral strategy concerned the identity of those individuals maintained as secretary-generals of sub-sections of the PDCI, later nominated as deputies to the National Assembly (Cohen 1974: 175). It should be noted that under Houphouët-Boigny and the PDCI deputies consisted of people loyal to the regime, with limited or no knowledge of government. Some deputies could not read and write even. The case of the late Kassoum Coulibaly, a rich Senufo transporter from Korogho (north) was an example in point. Such flaws were permissible as there was no apparent opposition during that time. What mattered was the ethnic or regional posts distribution all the branches of government.

On the economic front, the initial division of labor or occupation was a natural one, and it varies from region to region. Though, agriculture constitutes the most important occupation for well over $60 \%$ of people nationwide. The Akan mostly cultivate cocoa, coffee, rice, pineapple, bananas, and rubber trees, while Senufo farmers specialize 
in rice, sugarcane, millet, mangoes, and cotton. As for Bete farmers; they grow rice, coffee, and cocoa; while farmers of other groups tend to have small plots growing a variety of the above crops. Commerce it is largely controlled by Dyula and Malinké traders, with men dominating large-scale trade and women prominent in small-scale trade. The transportation sector has been led predominantly by Dyula, as well as Kulango, Baule, Anyi, and Bete men, while forestry has largely been left to the Lebanese, European businessmen, and some political elite (Kouadio 2007, and Bassetts 2003).

Meanwhile, many farmers started to move to rich soil areas hoping to capitalize in cocoa and coffee production. A massive migration to the west ensued, which changed the population dynamics in the region, and also created serious environmental concerns. People of other regions, as well as foreign immigrant were able to acquire portion of the land to grow their own cocoa and coffee. As time went by, incidence started to arise, sometimes leading violence between the locals and these migrant workers. These clashes were fought alone ethnic and regional lines. Because, it had no sound laws regarding land tenure, the government failed to address the problem, which resulted in several deadly clashes between the alleged landowners and migrant workers in Gagnoa and Issia (west), and San-Pedro (southwest) regions. In the past, these groups were able to live in nearperfect harmony. Unfortunately, this relative unity on the surface had been broken due to new economic and political developments.

\section{B. Dis-Unity Under the Subsequent Regimes (1993-2002)}

In 1990, a new political dynamic emerged in Côte d'Ivoire in which the Houphouët-Boigny regime was forced to adopt multiparty elections for the first time, 
after well nearly four decades of single-party system. Several important, as well as insignificant political parties were created as a result of this. The most important of these parties were the Ivoirian Popular Front (FPI) of Laurent Gbagbo, and Ivoirian Workers Party (PIT) of Francis Wodie. Table 5 below shows the names of the main political leaders, birth places, ethnic affiliations, and time spent in power.

Table 5: Major Parties and Leaders' Affiliation

\begin{tabular}{|c|c|c|l|}
\hline POLITICAL PARTIES & LEADERS & ETHNICITY & YEAR \\
\hline $\begin{array}{c}\text { Democratic Party of Côte } \\
\text { d'Ivoire (PDCI) }\end{array}$ & $\begin{array}{c}\text { Houphouët-Boigny } \\
\text { Henri Konan Bédié }\end{array}$ & $\begin{array}{c}\text { Baule- } \\
\text { Yamoussoukro } \\
\text { Baule-Daoukro }\end{array}$ & $\begin{array}{l}1960-1993 \\
1993-1999\end{array}$ \\
\hline Rally of the Republicans (RDR) & Allassane Ouattara & Dyula-Dimbokro & $1990-1993$ \\
\hline Ivorian Popular Front (FPI) & Laurent Gbagbo & Bete-Gagnoa & $\begin{array}{l}2000- \\
\text { Present }\end{array}$ \\
\hline $\begin{array}{c}\text { Union for Democracy and Peace } \\
\text { in Côte d'Ivoire (UDPCI) }\end{array}$ & Robert Guéï & Dan-Biankouma & $1999-2000$ \\
\hline Over 20 smaller parties & & & \\
\hline
\end{tabular}

Source: Adapted from CIA Factbook (2001)-Côte d'Ivoire

As time went by, new parties were added to the list. An example of this was the Republican Democratic Rally (RDR) created by the late Djeni Kobina, who led a dissident group that left the Democratic Party of Côte d'Ivoire (PDCI). The new political dynamics and the fracture within the old party completely changed the political landscape in Côte d'Ivoire.

At first, these were ideological parties that sought to correct the so-called mistakes of the first regime. They all claimed to be against the Houphouet-Boigny political agenda, especially the single-party system. Thus, they formed a common front against the PDCI. As time went by, many of them could not be sustained, forcing their 
members to join other parties or go out politics for good. While multipartyism opened the doors to more political competition and participation, it also created many problems in the Ivoirian political arena.

Tensions grew even greater with the entry of Allasane Ouattara (an alleged Burkinabè) on the political arena, as the country's first prime minister in 1990. Immediately after Houphouët-Boigny's death in December 1993, Ouattara displayed his ambition to run for the highest office. Then, the battle for the succession between Ouattara and Bédié began. A number of painful events ensued, which divided the country along ethnic and religious lines. In fact, a number of painful events had occurred under Ouattara (1990-1993) when he was prime minister, and Bédié as interim president (199395), and as president (1995-1999). Both leaders neglected and downplayed the social cohesion that was created by Houphouët-Boigny and the PDCI over three decades by manipulating their respective religious and ethnic followers. Bédié especially created the xenophobic concept "Ivoirite"" which aimed at defining who was a citizen and who was a foreigner.

In December 1999, General Robert Guéi led a military coup that overthrew Bédié. Guéï claimed he had come to clean up the mess created by the Bédié regime, and return power to the civilians. The junta held power for nine months. Unfortunately, the so-called liberator and his followers continued to victimize certain Ivoirians and foreigners. In the end, Guéï did not keep his promise to return power to the civilians. Instead, he decided to run for the Presidential 2000 elections. Worse, he excluded Bédié and Ouattara from running for the presidency in 2000 . Thus the main contenders for these elections were 
Gbagbo and himself. Gbagbo won the elections, but Guéi tried to steal it. When Ggagbo assumed power, he also failed to re-unite the country. He indirectly and directly created more discontents among the people. These ethnic and religious rivalries or tensions had sparked fear, distrust, and suspicion among the people across the country under the Bédié, Guéï, and Gabgbo regimes.

Under Houphouët-Boigny, these tensions were mitigated and eased by government policies of rewards. The president created a model of ethnic and religious tolerance that was promoted using mass media, administrative, ideological, and other means to promote positive communication and interaction among members of different ethnic and religious groups. Following Houphouet's fall, a variety of factors, including constant armed forces and police harassments of certain groups promoted division between ethnic and, especially, religious groups. Such divisions initially began with electoral politics and then spread beyond electoral issues (Kouadio 2007). Also, see pictures of leaders and affiliation in Apendix C (p. 215).

Steck (2002: 4) notes the Ivoirian case that the identity crisis and the tensions between groups (national, ethnic, and religious) exacerbated everything...the electoral context and the fight among the major leaders for the presidency precipitated the crisis. According to him, the death of Houphouët-Boigny in December 1993 changed everything, and it moved the debate toward the fight for succession won by Bédié originally supported by Guéi against Ouattara. However, the main source of rising ethnic tensions was due to the political insecurity in the country (Steck 2002: 6).

According to the same author, Bédié used the concept of Ivoirité against Ouattara. The Ivoirité is a concept based on the following three principles: First, deny Ouattara's 
nationality, and most importantly Ouattara's relation with Côte d'Ivoire (due to its lineages within Burkina-Faso) and the foundation of Ivoirian identity, in part because he was from a northern region where the cultural, religious, and historical influences cross over, are multiple, where the colonial borders were drawn over three ethno-linguistic between three states (Mali, Côte d'Ivoire, Burkina Faso). Second, its purpose was to deny Gbagbo as the main and historical opposition figure-a Bete, who incarnates or carries the clichés of the old rivalry between Bete and Baule. Third, go into retreat in his hometown, Daoukro (center), managing the local clientelism, image of a man the terrain and fidelity to the Akan people where Houphouët-Boigny was a symbol. Hence, Bédié had opened up the presidential bid on the basis of national authenticity, guaranting the authenticity of being an Ivoirian. But, the explanation of the crisis should go on and must not stop at the breakdown of national unity alone. Perhaps a good look at the compositions of the various forces on the ground can offer more insights as well.

\section{Composition of the Competing Military Forces}

In this section I examine the composition of the two competing military forces that are involved in the civil war in Côte d'Ivoire. First, I examine the composition of the ensemble of the three rebel forces (also called the New Forces or FN). Second, I look at the composition of the national armed forces of Côte d'Ivoire (FANCI). Understanding the composition of these two camps is critical, for it may help explain, in part, why these rebel groups, and not others, took up the arms against the Gbagbo regime?

\section{New Forces (FN)}

The insurgency against the Gbagbo regime consisted of exiled former soldiers and co-conspirators in Abidjan, who simultaneously attacked government leaders campounds 
and institutions, and security facilities in Abidjan (south), Bouaké (center), and Korhogo (north) (U.S. State Department, 31 March 2003). The Patriotic Movement of Côte d'Ivoire (MPCI), Ivoirian Popular Movement for the Great West (MPIGO), and Movement for Justice and Peace (MJP) joined together to formed the Forces Nouvelles (New Forces) (Welsh 2003).

The military branch of MPCI consisted of former servicemen who participated in the overthrow of President Bédié on 24 December 1999. These officers included Ibrahima Coulibaly (also known as IB), Zacharia Kone, Tuo Fozie, and Massamba Kone (all northerners from Senufo and Dyula ethnic groups). These soldiers had been detained and tortured under the junta (1999-2000) led by General Robert Guéï. They had escaped and fled to Burkina Faso after they attempted to overthrow the regime of President Gbagbo on 7 and 8 January 2001 (Zoro 2003).

Note that the exiled soldiers that led the attacks were under the command of Staff Sergeant Ibrahim Coulibaly, a Senufo from the north. They began the preparation of the armed movement in Ouagadougou (Burkina-Faso) in 2001. Other superior officers of the FANCI also joined the rebellion. However, these were from other ethnic groups. Among them were Colonel Michel Gueu (a Guere from the west) and Colonel Soumaila Bakayoko (Dyula from the north). Many other soldiers have joined the rebellion as mercenaries from Burkina Faso, Liberia, Sierra Leone, and Guinea-Conakry (Diallo 2005: 13-14).

The political branch of MPCI was led by Guillaume Soro, an ex-University student organization leader who served as Secretary General. Before he joined the rebellion, Soro was an influential member of the (now) powerful and feared University 
organization, the Federation Estudiantine de Côte d'Ivoire (FESCI). The FESCI was basically created in the late 1980s, and early 1990s when Côte d'Ivoire was experiencing a huge political "earthquake" that led to the adoption of multipartism. With regional branches located throughout the country (including Universities, technical and high schools), the FESCI's main purpose was to fight for the rights of all the students, namely their working and living conditions. That is, it served as a civil organization that mediated between the student body and the government.

Unfortunately, as this is common across Sub-Saharan Africa, the FESCI was quickly transformed from its original mission, when the political elite sought to recruit followers among the youth in general and students in particular. This divided the FESCI, especially the leadership. Consequently, several pseudo-associations of students emerged that did not have the impact the original FESCI had. A great deal of animosity divided this organization further, leading to sporadic clashes between the various factions. It was in that context that machetes were introduced for the first time, both on campuses and in students' dormitories. The same context produced the two most powerful youth/students leaders during the pick of the crisis, Guillaume Soro and Charles Ble Goude, both became known to the general public and the country.

When the civil war started Blé Goudé and his pro-Gbagbo followers called for patriotism and demanded that all stood up and defender the Republic, therefore the Gbagbo regime. Ble Goude and Gbagbo are both Bete from the west. Ble created the Alliance des Jeunes Patriotes to fight the rebellion led by his old friend and colleague Soro, who had become the emblematic figure, or for lack of better word, the visible face of the rebellion in Côte d'Ivoire. 
According to Welsh (2003), a British Broadcast Corporation (BBC)

correspondent in West Africa, the main and original rebel force (MPCI) began as a group of around 700 soldiers from various backgrounds who took up arms against their own country, because they were about to be demobilized against their wishes. Some of them joined the army when Guéï was in power, while others had participated in the coup that overthrew Bédié in December 1999. These soon to-be-demobilized soldiers were joined by ex-soldiers, who had been living abroad, who also recuited heavily in the areas it occupied (inckuding the north, center, and west). They demanded that President Gbagbo step down, and that fair, and transparent elections be organized within six months, that will be open to all Ivoirians.

Initially, the government accused the MPCI of being sponsored by some neighboring countries. Burkina Faso, for instance, was occasionally single out and accused by the Gbagbo regime for serving as a safe heaven for the rebels, though there was no evidence to support such claims. Seven years, there still is some mystery about the rebellion that has yet to be revealed or answered. As Welsh (2003) puts it: "one thing that is clear is that the rebels are getting funds from somewhere. What is even clearer is that the new shady groups do have links across the borders."

Diallo (2005: 15) also argues that after the outbreak of the civil war, the MPCI was able to quickly mobilize the dozos, who then took an active part in the rebellion. The donsos or dozos who are traditional hunters from Bambara origin (from Mali) are longstanding voluntary associations of men carrying guns. They dress in traditional uniform, wearing gris-gris (mystic power), and accessories like a fly whist, whistle, and hunting 
knife. The dozos also claim to have healing skills, and are feared by others. To be a dozo is a matter of individual choice, and recruitment is achieved by co-optation. Conditions of belonging to a dozo association (or donsoton) include the ritual observance of common values based on the moral and intellectual probity of group members, including respect, courage, cooperation, and internal solidarity. In Côte d'Ivoire, most of the dozos are from the Senufo, Dyula, and Malinké ethnic groups (their number is estimated to 40,000 dozos).

Diallo (2005: 14) also writes that the total number of dozos fighters mobilized by MPCI is not exactly known, though the international Crisis Group (ICG) has estimated their number at 1,000 fighters, including at least 500 from Mali. MPCI reportedly recruited at least 10,000 civilians. Other dozos joined the rebel faction MPCI in Bouaké (center) and Korhogo (north). But, why and how did it come about that the dozos sided with the northern rebel groups?

Before joining the rebellion, the dozos assumed the role of a supplementary police force for several years. In fact, their mobilization began in the 1990s. In 1994, the northern region became increasingly lawless. Therefore, Colonel Issa Diakite, a former administrative officer in Korhogo (MPCI Minister of Territorial Administration) in the Government of Reconciliation, appealed to the dozos for assistance. Subsequently, they were given the assignment to combat rural banditry (Diallo 2005: 15).

One must not underestimate the fact that the north and west under rebel control constituted a large reservoir for recruiting fighters. In fact, the MPCI, MJP, MPIGO heavily recruited young women and men under their direct control during their occupation, either by will or force. As the next section will show the composition of 
MPIGO and MJP largely reflect their own base, dominated by Yacuba and Guere fighters, these two groups belong to the generic language community known as Mande. As for the MPCI, its ethnic composition remains arguably complex because of the huge territory it controls. For instance, it has juridiction over important ethnic groups from the north, center, and northeast. These ethnic groups include the Senufo, Malinké, Dyula, Tagbana, Djimini, Baule, and Abron. The majority of them are mostly northern and Muslim (some Senufo are not Muslim), Baule who practice some types of Christianity or African traditions (Diallo 2005).

If the identities and roles of the rebel leaders were clearly established during the first hours of the civil war, it was not the case for their fighters. There have been many mysteries surrounding the origins of certain rebel fighters, and most importantly their sponsors. Some scholars and journalists have attempted to quantify the composition of thre rebel army, but no one actually knows exactly how many foreign and local fighters there were? How many were killed during the battle following the uprising? Another problem is that most (if not all) foreign fighters have already gone back to their homes, as have local fighters whose promises were not met by rebel leaders. Also, it is unclear who trained, sponsored, and equipped them with the sophisticated logistics or equipments such as radios, satellite telephones, or machine-guns, which the rebels had displayed during their occupation of the second half of the country. There have been rumors, and finger pointing in the local press, internet blogs, while the rebels remained silent about the attack (LePape 2003: 30)

Welsh (2003) also highlightes the mystery about the involvement of foreign fighters in the border with Liberia. He notes that during the Liberian civil war, Yacuba 
and Guere were recruited to fight alongside some Liberian rebel groups. Therefore, it is no surprising to see the same favor being returned to their ethnic brothers in order to abenge Guéï. That during a BBC interview with Felix Doh and Gaspard Deli, respectively leaders of MJP and MPIGO, the two had confessed that they were fighting because Guéi (a Yacuba from the west who was killed) was an ethnic "brother". Ironically, Gbagbo had come to power by defeating Guéi during the controversial 2000 presidential elections from which other significant opposition leaders (namely Ouattara and Bédié) were excluded. When Guéi decided to proclaim himself the winner, Gbagbo asked his supporter to storm the presidential palace. They did, and Guéi fled. Many of these Liberians, however, appeared to be more interested looting than as a struggle for any cause, welsh writes. They came from Liberia and Sierra Leone, two countries that have both suffered from long vicious and interrelated wars involving numerous rebel movements. The rebels from these two war-torn West African countries, and from Guinea, had supported and provoked each other's conflicts; now it seems they were ready to do do the same in Côte d'Ivoire.

While I was doing dissertation research in Côte d'Ivoire, I learned that in a clash between MPIGO/MJP fighters, and the national armed forces of Côte d'Ivoire (FANCI) in Man and Danane regions (west) some of these alleged foreign fighters were apprehended and shown on national television. The authorities displayed them to convey foreign involvement in the crisis. Some of these fighters allegedly spoke English and other tribal languages from Liberia and Sierra Leone. They had allegedly confessed that they were recruited to fight in Côte d'Ivoire, though they did not reveal for how long and 
the compensation for their service. Also, neither MPIGO nor MJP leaders officially confirmed or denied the presence of foreign fighters in their midst.

It was unclear whether this was propaganda on the part of the Ivoirian government, a tactic used by it to deter more foreign fighters from getting involved, or was it an invitation to the international community, and the governments of these neighboring countries to do something about it? So far, there have been no answers to these questions. And no one has attempted to give one publicly or officially.

In sum, the MPCI, MPIGO, and MJP were led by ex-servicemen, who had in their midst officers and low ex-soldiers, who were apparently unhappy about their conditions in general, and particularly the army. As time went by, they started to make new demands, including political ones. These rebel groups also recruited in the neighboring countries with the exception of Ghana, which was not accused of any involvement in the war. The foreign recruits fought alongside a huge pool of local recruits, especially from the Muslim north.

The New Forces also drew some strong support from many towns across the country, especially among foreign and Muslim communities. But many of them could not voice their origins publicly for fear of retaliation against their families by the government forces, or its sponsored militia groups that mushroomed in the southern half of the country controlled by it. The reasons for their support of the FN were twofold: First, they perceived the rebels as their saviors, who who could put an end to the harrasment and brutality perpetrated against them along with their northern counterparts. Second, they saw in the rebellion a group they could count on and join forces to fight for social, economic, and political justice. 
These observations show that the current crisis is one among the country's ethnoregional groups. The MPCI was highly dominated by northern constituencies, while the other two, MPJ and MPIGO, were filled with Yocuba and Guere from the west. Few other ethnic groups were also involved. For instance, Colonel Michel Gueu is a Yacuba from the west, and former MPCI minister of sport in the Seydou Diarra transitional government. The late MPIGO leader Felix Doh was a Baule who camouflaged his real name and origins during the first hours of the rebellion. As for Kouakou Fofie, he is an Abron (northeast) who joined the MPCI, currently the military commander in Korhogo (north), while MJP leader Gaspard Deli is a Guere from the west. Louis Dakoury Tabley (current MPCI minister) and Alain Lobognon (MPCI communication director) are Bete from the west, as is President Gbagbo himself. Now is what war the composition FANCI like?

\section{National Armed Forces of Côte d'Ivoire (FANCI)}

In multi-ethnic societies such as those of Sub-Saharan Africa, the internal composition of a so-called national army may take two forms, each with its costs and benefits. The first type reflects an army that is ethnically balanced, and one in which the major ethnic groups are somewhat well represented from the top down. The second type is an army dominated by one or two major ethnic groups, or representatives of one major national region. Sometime regionalism matters more.

The first type of army may be advantageous to a ruler in that it reflects the social fabric of the country. In other words, it is representative of all ethnic groups. There is a sense of stability in it. In this case, the president, who is commander-in-chief, may be forced to respect the rule of law in his relations with the armed forces. The disadvantage, 
however, is that an ethnically balanced army may be hard to manipulate, thus detrimental to the policies of the president and his government. Some do fairly well. In fact, no country in the world has an army that is perfectly balanced, let alone Sub-Saharan Africa.

The second type of army is typical of most Sub-Saharan African countries. In this type, the army is dominated either by a single ethnic group, usually the ethnic group of the president, and led by officers very close and loyal to him. Moreover, the minister of defense is usually a trusted friend or relative of the president who appoints him. These arrangements are crucial in the African context, as the army, gendarmerie, presidential guards, and police are great instruments of both law enforcement, and political coercion in most countries. Note that there is often a difference between the regular army (ethnically diverse) and the favored praetorian guards, who are completely loyal to the president (Decalo 1976 and 1989).

In a chaotic situation such as the one discussed here, these organizations are often called upon to quell uprisings, riots, rebellions, protests, attempted coups, etc...The disadvantage of an army that is dominated by one or few ethnic groups is that such arrangements can easily create an atmosphere of suspicion and friction within the organization, whereby excluded or minority groups seek to unite against the dominant group. Such patterns are the recipe for political instability. Many African rulers with an ethnic army have ruled over stable regimes: Mobutu in ex-Zaire, and Bongo in Gabon, for example. The current composition of the armed forces in Côte d'Ivoire reflects this second type. But, this is nothing new. The current turmoil in the army, which Kieffer (2000) has documented, did not suddenly start under the current regime, which is now 
paying the ultimate price. It started under Houphouët-Boigny, and continued in the following regimes. In fact, since the death of Houphouët-Boigny in December 1993, each of the subsequent regimes (Bédié, Guéi, and Gbagbo) has had its share of turmoil.

Under Houphouët-Boigny, the army was ethnically balanced. However, the Minister of defense was a Baule, a loyal ethnic brother of the president. For example, Mbahia Blé Kouadio, a Baule from Mbahiakro (center-east) held this position for a long time. His brother Colonel Mbahia was also among the army elite at the military base in Bouaké (1970s and 1980s). Houphouët-Boigny's Chief of Staff was also a Baule. However, he allowed other ethnic groups to lead as well. An example was General Ouattara Dakin (a Taguana from Katiola, north), Colonel Oulai (a Guere from Man, west), General Guéï (a Yacuba from Biankouma, west), General Zeze Barouan (a Bete from Issia, west), General Palenfo (a Lobi from Bouna, northeast), and General Coulibaly (a Senufo from Korhogo, north). There were similar ethno-regional representations in the gendarmerie, police, and navy (for example, Admiral Lamine Fadiga, a Mahoka from Touba, west).

Both the mutinies and rebellion in Côte d'Ivoire must be understood in relation to the prevailing socio-political situation, and in the context of changes generated by army reform. The same ethnic and political cleavages that run through the Ivoirian society exist in the armed forces and the police. The FANCI and police suffer from not only low salaries and poor conditions, but also ethnic nepotism. Since Bédié, Guéï, and Gbagbo came to power the tendency has been to recruit soldiers based on ethno-regional origins (Diallo 2005, Coulibaly 2002, and Kieffer 2002). For example, Gbagbo was accused of 
the Bete-ization and Dida-ization of the armed forces, in addition to ethno-regional militias. The Bete and Dida are two regional groups that live side by side and very close to each other in many respects including history, language, and culture. Since he came to power, President Gbagbo appointed Bete and Dida at the highest positions in the armed forces, to allegedly secure power. The situation may have contributed to the frustration of ex-soldiers who took at arms against his government.

While the size of the army was limited to few thousands soldiers under the Houphouët-Boigny and to some extent the Bédié regime, its nature drastically changed under Guéi and Gbagbo. From 1999 to 2002, the number of young recruits increased the number of army personnel, police, gendarmerie, and navy and forestry, to alledgely secure the two regimes.

Diallo (2005) argues that despite a lack of equipment, the armed forces experienced a rapid expansion, with recruitment of young soldiers especially under Guéï's junta in 1999-2000. The majority of these young soldiers, recruited according to their ethnic affiliation, were members of special paramilitary units known as Zinzins and Bahefoues. With the help of President Taylor in Liberia, Guéï recruited a number of Liberian and Sierra Leonean fighters for his presidential guard, known as the Red Brigades. That the actions of the Red Brigades and other special units, like the Camorra and the Cosa Nostra, to which Guéi delegated security, resulted in a land of military factionalism.

In September 2000, soldiers of the Cosa Nostra, indicted for plotting to overthrow the Guéi junta, were arrested. Among those who took refuge in Burkina Faso were the 
leaders of the current rebellion. The situation in the army worsened in January 2001, when a group of soldiers revolted against the presidency of Gbagbo. Loyal troops tot eh presudent subdued the rebellion, while the young northern soldiers who had led it fled and found refuge in Burkina Faso (Diallo 2005: 13).

In January 2002, Moise Lida Kouassi, the then Minister of Defense, announced a reform program for the army. The imminent demobilization of paramilitary units caused resentment and exacerbated frustrations. Members of the Cosa Nostra, Zinzins and Bahefoues units considered too close to Guéï were expected to be demobilized. Lida Kouassi also unilaterally removed two major northern officers (Generals Palinfo and Coulibaly) also considered to be close to Ouattara's party (RDR), and replaced them with southerners in Bouaké (center).

It was a mistake on his part to replace a disloyal officer with another disloyal one. For example, Lida Kouassi sent Colonel Michel Gueu (an officer from the west), who was responsible for the presidential guard of Guéï, to Yamoussoukro first, and later to Bouaké, where he became one of the senior officers of the current rebellion. The situation in the army and the subsequent changes in the security forces, leading to the exclusion and frustration of former soldiers, triggered the armed conflict (Diallo 2005: 13).

It should be noted that at the time the attack was perpetrated in September 2002, the army was in a bad shape in all the aspects including equipments, training, and morale to go to war. It had few combatants with no war experience, and very limited (but also updated) logistics or equipments. There are several explanations for this. The first explanation is that the country had experienced such a long period of stability that the leaders thought the probability of a war was almost zero. 
The second explanation is that under the single-party regime, the likelihood of war with another country was minimal or inexistent, for Houphouët-Boigny had great influence over the neighboring countries, and their leaders. He was also well respected in the region, and his open door policy to towards foreign migrant workers gave the leaders of neighboring countries a sense of brotherhood and tranquility that they did not want to undermine.

The third explanation, and perhaps the most important, is that at independence Côte d'Ivoire had signed multiple agreements (including one military) with France in which the former colonial power vowed to intervene militarily on its behalf, in the advent of internal and external aggression. Côte d'Ivoire was a symbol of the French presence in West Africa for many years. To be sure, France stationed a battalion of hundreds of its soldiers in that country since independence near the Felix Houphouett-Boigny airport, the distrit of Port-Bouet. If needed at all their numbers will be increased in a timely manner, as there are several other French bases across Francophone Africa, in Dakar (Senegal), Liberville (Gabon), and Chad (Ndjamena), Bangui (Central African Republic), and Djibouti (Djibouti) (Manning 1982).

There was this anecdote among the Ivoirians during the Houphouët-Boigny era that the nationale armed forces of Côte d'Ivoire were an army of officers, for it had more officers than servicemen. That the bellies of these high ranked officers demonstrated that they were fed well by the system, thus they did not rebelling against the system. Their big bellies also suggest that in the advent of an aggression the army would not be able to fight, and win against the ennemy. Unfortunately, these jokes about the army of Côte d'Ivoire revealed some truth, as the rebel groups seriously challenged government forces 
on the night of the uprising in September. Despite the warning signs that were visible to most observers, the war seemed to have surprised the armed forces and cohort of officers, and the fact that the army was not prepared fully meant it could not sustain a long battle against the enemy. In fact, the first clashes with the rebels on multiple fronts attest to this fact. Both sides suffered significant collateral damages. The armed forces suffered huge losses in materials and combatants in particular.

In fact, Radio correspondents form the British Broadcast Corporation (BBC) and Radio France International (RFI) had reported that the rebels had more sophisticated communication tools than the national armed forces. The French soldiers were accused of allegedly supporting and sharing secret information with the rebels about the planning and liberation of the strategic town of Bouaké, now the headquarters of the rebellion. The same radio outlets also reported that desperate as it was, the government with the help of the people who did not support the rebellion took upon themselves to recruit more fighters and buy some ammunition. These fighters were maid up of both ethno-regional, government-created militia groups, as well as those groups who did not share the rebellion cause, or who had lost everything and fled the rebel-controlled areas to seek refuge in the government control one. The governent was able to acquire two warplanes (Sukoi MI-24) from an Eastern Europe country in the hope to crash the rebellion. Meanwhile, the government recruited many young people and ethnic militias (mainly of Bete descent) to re-establish order throughout the country. President Gbagbo recruited ethnic militias and paramilitary forces, and mobilized thousands of southern youths with the help of the main student organization (FESCI). A presidential decree on 9 December 2002 allowed the government to recruite 3,000 youths into the army and a 
further 1,000 in early 2003 (Diallo 2005: 17). These new recruits were mainly from the south, pro-Gbagbo, and claimed to be proud defenders of the nation.

A 2002 International Crisis Group (ICG) also reported that an estimated 6,000 youth were recruited into the armed forces. The students and other youth movements formed a coalition called Alliance Des Jeunes Patriotes Pour le Sursaut National. It was also alledged that the Gbagbo government hired European, South African, and Angolan mercenaries estimated to 500 that helped the FANCI to recover Daloa on 17 October 2002, when the rebellion tried to take over the entire cocoa belt.

Based on the explanation above, one can argue that the internal compositions of the FANCI and the FN were highly ethnic and regionally based. Moreover, their respective leaderships tended to be dominated by persons whose images were directly associated with an ethnicity, religion, and region. On the one hand, MPCI members consisted of northerners, and Muslim. As for MPIGO and MJP fighters, they were Yacuba and Guere, while the majority of the nationale forces were of Bete and Dida descent (Kieffer 2000 and 2002).

It should be noted that the Gbagbo regime made some adjustment in order to reposition some army leaders, and to accommodate individual desires (including his own), and for the future. The government admitted (after the fact) that it had a weaker army that needed to be rebuilt and reformed.

The present chapter has shown that ethno-regional differences have shaped the contours of the current conflict in Côte d'Ivoire, demonstrated by the composition of the people involved on the government and rebel sides, and the goals they tried to achieve. Political stability can be achieved only when there is social cohesion. In this case, ethno- 
regional tensions rose up because the subsequent regimes failed to maintain that social cohesion under the new political context.

The contemporary civil war in Côte d'Ivoire, which began in September 2002 and continued into 2007, has been fought mainly by an alliance of northern rebels, mostly alienated youth and ex-soldiers who have (allegedly) been tired of the north's marginalization. Rather than seeking secession, they aimed to oust President Laurent Gbagbo, a southerner, and to gain control of the government. The armed struggle in Côte d'Ivoire is indicative both of the long-term state neglect serving to generate regionally anchored rebellion and of the extent to which the failure of nation-state integration and the diminished institutional capacity of the state can make it possible for a rebel alliance to seize control of the vast territories (Forest 2005: 33)

Because the state is the supreme resource, power is needed for gaining access to other resources and building wealth and status. In the power struggles the politicians are the principal actors who appeal to ethno-regional loyalties to gain support and acquire or preserve privileged positions. The politicization of groups' identities has sharpened ethno-regional divisions, exacerbated tensions and created a cycle of violence among various ethnic communities living in Côte d'Ivoire. The same ethnic and political divisions that characterize civil society also exist in the army and police. The recent military factionalism, added to the changes in the security forces, has aggravated frustration within the army and caused mutinies, culminating in a rebellion on 19 September 2002 (Diallo 2005: 3). 
During his tenure, Houphouët-Boigny was able to manage ethno-regional tensions by co-opting representatives of all regions and ethnic groups in his party and offered them positions in the administration and the army, through the "politics of distribution" and co-optation, he provided personal friends and traditional chiefs-including those from the north-with financial resources and different kinds of services in return for electoral and political support. The politics of distribution of resources and positions, which contributed to the easing of tensions, was the key to managing conflict. The president was somewhat like Yugoslavia's Tito who was able to ward off the rise of ethnic conflict until his death. Since 1993, the appeal to ethnic loyalties has come to characterize political competition. Differences between PDCI, RDR and FPI are no longer ideological, but phrased in ethnic terms. Each party is identified with the ethnic group of its leader (Diallo 2005: 7 and Tessy 1997: 58).

The ethno-regionalism and widening of the north-south divide are phenomenon manifesting itself through a different access to power, services and wealth. The north/south divide remains one of the major political challenges for contemporary West African states as a whole, and Côte d'Ivoire in particular. This is at the heart of the current crisis that started under the Bédié leadership, and got intensified by both the Guéï and Gbagbo regimes. 


\section{CHAPTER 5}

\section{ROLE OF FOREIGN RELATIONS IN THE CIVIL WAR}

Chapter five is an analysis of the role of foreign relations in the civil war in Côte d'Ivoire. First, it gives a brief overview of Franco-African relations in order to put the Franco-Ivoirian relations in context. Second, it examines the Franco-Ivoirian relations under the first and sunsequent regimes. Third, it discusses the regional political context, that is, the relations between Côte d'Ivoire and its neighbors (Ghana, Liberia, Mali, Burkina Faso, and Guinea-Conakry). The existing literature suggests that the FrancoIvoirian relations cannot be understood in isolation, they must be examined in a broader context of Franco-African relations, while the regional political context must be put in historical perspective.

In other words, the current chapter seeks to understand whether the war broke out because the former colonial power, France, withdrew its support from President Gbagbo, and wether it was hostile to the Gbagbo regime in a way that it was not to the regimes of Houphouët-Boigny, Bédié, and Guéï. The chapter also wants to learn whether French aid declined or dropped off after Gbagbo's election in 2000, or if the French rhetoric changed after President Gbagbo came to power. If so, when and how did this happen, sending a signal to would-be rebels? The regional political context will help me discover whether the war broke out because the neighboring countries encouraged the rebellion. Also, did France signal to these neighboring countries that their intervention was acceptable? Did these neighboring countries have their own motives for intervening in the conflict? Why such intervention was thinkable under President Gbagbo, but not previously? 


\section{A. Franco-African Relations: An Overview}

There is a large consensus among scholars that French policy in Africa can be divided into two distinctive periods. First, there is the old policy that covers the Cold War period (roughly 1947-1991). Second, there is the new policy of the post-Cold War period (1991 to present). The first policy consists of the 'successful management' by France of the decolonization process period (for example, absence of wars of decolonization, transition to full independence without large-scale violence or bloodshed, and France's ability to maintain its post-colonial presence in French Africa, and France's close ties with Africa during the the post-colonial period). The second policy that dominates the Franco-African relations is France's 'disengagement', and the so-called 'normalisation' of these relations (Chafer 2001: 165, Martin 1995 and 2000, and Levine 2004).

The signs of disengagement, however, include the reduction of French coopérants working in Africa since the 1980s, notably in the education field; the devaluation of the CFA Franc in 1994; the reduction of French military forces stationed in Africa in the 1990s; and the increased unwillingness to intervene militarily in Africa since the controversy over France's role in the Rwandan genocide of 1994 (Chafer 2001: 166, Martin 1995 and 2000, see also Lavine 2004). France and its former colonies have cultivated close relationships that seem unbreakable on the surface in many ways.

At the military level, for instance, Black Africa has been the chosen zone for the projection of French military power beyond the metropole. Examples of these are the signing of a series of defense and military accords with the former colonies, the stationing of French troops in several countries (Côte d'Ivoire, Gabon, Central African Republic, Djibouti, and Senegal), and a series of military interventions, which took place 
at an average rate of one a year in the first thrirty-five years after independence (Chafer 1996: 557-64, see also Gardiner in Clarck/Gardinier 1997).

At the economic level, the deployment of French public development aid, the great majority of which has gone to France's former Black African colonies, has served to underpin French strategic interests in the region (Chafer 1996: 556, also see Levine 2004).

At the ideological level, France has cultivated a sense of association and common heritage with Africa, which has served to cement the links between them, both during and after the colonial period, the projection of the 'universal' French republican values, liberty, equality and fraternity offered generations of French-educated Africans in the hope of progress and the prospect of a partnership with France to bring it about (Chafer 2001: 68).

The first phase (also called period of continuity) of these relationships did not see any major changes on the ground. All the private and public treaties remained intact, and were respected by both sides due to the Cold War context. The second phase came with significant changes, which neither France nor Africa had full control over. The Ivoirian crisis must be looked at in the last context.

The new Franco-African policy since the 1990s has been marked by distinctive events that have served as powerful tools to explain this relationship. Six separate (though interrelated) events are symbolic of France's new African policy including: the passing of Houphouët-Boigny (1993) and Jacques Foccart (1997); the la Baule doctrine; the Abidjan doctrine and the devaluation of the CFA Franc; French setbacks in the Great 
Lakes region, the Zairian debacle; Franco-South African rapprochement; and revised French immigration policy (Martin 2000: 6).

The passing of two key figures of "La Françafrique", Felix Houphouët-Boigny (December 1993) and Jacques Foccart (May 1997) truly signaled the end of an era in the Franco-African relations. When he died in December 1993, Houphouët-Boigny had been president of Côte d'Ivoire since August 1960 and was unquestionably the Dean of Francophone Africa and key ally of France in the region. His personal ties with several generations of French leaders were reflected in the level and size of the French delegation to his state funeral in Yamoussoukro in February 1994, which included the late French President François Mitterrand, Prime Minister Eduard Balladur, former President Giscard D'Estaing, six former prime ministers, and more than seventy other dignitaries. As the New York Times envoy stated well, "Houphouët-Boigny's death is not the end of a political era here, but perhaps as well as the end of the close French-African relationship that he came to symbolize." (Martin 2000: 6-7).

During the cohabitation regime in which a socialist president (François Mitterrand) co-existed with a right-wing government (with Charles Pasqua as Minister of Home Affairs) — between 1986 and 1988, and between 1993 and 1995, France enacted extremely restrictive immigration policies specifically targeting francophone Africans (including Maghrebins from North Africa). Taking various disaggreable forms drastic reduction in the delivery of entry visas to France; multiplication of administrative obstacles and extreme bureaucratization of the visa issuance process, forced expulsion on charter planes of 'illegal' immigrants in humiliating conditions-French policy succeeded in antagonizing many francophone Africans (including students, businessmen, and 
politicians) and further contributed to a significant degradation of France's image in Africa (Martin 2000: 12).

In addition, France's non-intervention in the 24 December 1999 military coup in Côte d'Ivoire that overthrew President Bédié also marked a turning point. The decision must be viewed within the context of the new European Union's coordinated foreign policy under which France's bilateral African policy must henceforth thereafter be subsumed. French Cooperation Minister, Charles Josselin, had indicated that France's approach reflected a new policy of non-intervention in Africa. As he observed at the time, "We will no longer intervene in internal political debates."

Similar feelings were expressed by French Minister of Foreign Affairs (Martin 2000), Hubert Vedrine, when he remarked: "Disengagement from Africa is not on the agenda; nor is the intervention in internal conflicts, which now belongs to a bygone era." "This being said, we remain firmly opposed to any forcible removal of a legitimate government." The Bédié case clearly demonstrated that France wanted to show that it can be friendly without being complacent (Martin 2000: 18).

The Cold War had opened a 'space' on the international stage in which France was able to preset itself as the guarantor of Western interests in Black Africa, preserving it for the West and keeping it out of Soviets hands. In reality, France was motivated by the besoin de rayonnement on the global stage (Chafer 2001: 173). Following the end of the Cold war, France had to find ways to reduce the cost of maintaining its influence, including through the devaluation of the CFA franc by 50\% in 1994. France's introduction of economic conditionalities known as the Balladur Doctrine, which made the granting of French public development aid conditional upon the prior signature of any 
accords with the International Monetary Fund (IMF) and World Bank. The policy aimed at reducing cost to France of its African policy and thus making it more financially sustainable.

During the 1990 La Baule France-African summit Mitterand observed that those countries that undertook political reform signaled a significant break with past France practice. France's African reseaux continued to operate and even proliferated. The key strategic pillars in France's African relationship including Côte d'Ivoire, Senegal, Cameroon, and Gabon have remained the principal beneficiaries of French aid (Chafer 1996: 556 and 2001: 174).

The real post-Cold War turning point of the Franco-African relations was French role in the genocide of Rwanda (where 800,000 Tusi and moderate Hutus were killed). French support for the genocidal Habyriamana regime in Rwanda marked the nadir of French African policy and has been attributed to "France's failure in the mid-1990s to recognize and respond to dramatically changed circumstances in those parts of its expanded pré-carré (estate) it knew least well, a former Belgian colony" (Chafer 2001: 174).

Although there are some particularities in France's relations with specific African states, the situation described above affected all the francophone African countries across the board. Nonetheless, some francophone African states did not have a particular status with the former colonial power. The nature of these relationships depended upon France's investments and strategic interests in each country, including Côte d'Ivoire, which I discuss next. 


\section{B. Origins of Franco-Ivoirian Relations}

Côte d'Ivoire's first encounter with France dates back to 1637, when the first French missionaries landed at Assinie (southeast) near the Gold Coast (present-day Ghana) border. In 1843-1844, Admiral Bouet-Williaumez signed treaties with the kings of Grand-Bassam (southeast) and Assinie regions, placing their territories under French protectorate. French explorers, missionaries, trading companies, and soldiers gradually extended the area under French control inland from the lagoon region (south and southwest). Complete pacification, however, was not accomplished until 1915 (Mundt 1995).

The formal granting of Côte d'Ivoire as a colony of France came during the Berlin Conference (1884-1885) that sanctioned the scramble for Africa. It was the former German Chancelor, Otto von Bismark, who convened the fourteen Western European countries and the United States. The United States was invited as an oberserver nation, and was represented by John A. Kasson. Not a single African leader was invited to this important meeting that was to change the destiny of Africa and its peoples. The main objectives of the conference were the following; to break up the African continent into spheres of influence among the various powers; to establish the rules of engagement in order to avoid confrontation between Europeans on the ground; and to divide up the remaining unoccupied territories. France then formally occupied and ruled over Côte d'Ivoire virtually from 1893 until 1960, the date of its independence.

Unlike Algeria, Guinea-Conakry, Mozambique, or Angola (to name just a few), Côte d'Ivoire got its independence from France through negotiation. The smooth transition was facilitated by the fact that President Houphouët-Boigny had previously 
occupied several key legislative and cabinet positions in various French administrations during the late colonial era. He was a member of the French National Assembly, and also served for three years as a minister in the French Government (1946-1959). In April 1959, he became Côte d'Ivoire's first prime minister, and he was elected president the following year, making him a close ally and friend of the French (Baulin 1982, and Houphouët-Boigny 1994). These precious relationships were kept until HouphouëtBoigny died in December 1993.

It should be remembered that in April 1990, the Houphouët-Boigny regime officially allowed the formation of opposition parties for the first time. As a result, a plethora number of both fake and real opposition parties that definitely changed not only the political landscape, but also the political culture in that country were created. Expectedly, the advent of multipartyism brought swift changes at the domestic and external levels. These transformations became even more pronounced after HouphouëtBoigny died.

The death of Houphouët-Boigny in December 1993 created a power vacuum that needed to be filled right away. Bédié had won the succession on constitutional grounds and finished the 1990-1995 mandate of the dead president. In 1995, he was elected president after excluding his main political opponent, Allasane Ouattara, on the grounds that his biological parents were not of Ivoirian parentage (Konate 2004, Toungara 2001, and Akindes 2003). Also, Ouattara was accused of working at the International Monetary Fund (IMF) with a Burkinabè passport, thus making him inelligile for the presidency in Côte d'Ivoire. 
Ouattara and his followers were frustrated and took the streets to protest. Meanwhile, Bédié had created and infected Côte d'Ivoire and his supporters with a xenophobic concept "Ivoirite" that led to the division of the people along ethnic, religious and regional lines. The "Ivoirite" concept basically made one group feel to be more authentic citizen than the rest. This was an ingredient for ethnic division. Côte d'Ivoire is a multi-ethnic country where locals and foreigners have relatively lived peacefully sideby-side for decades without any major incident. However, police brutality against Ouattara's party officials, followers, and suspected pro-Ouattara foreigners from the Sahel region (especially Burkina Faso, Mali, and Niger) increased significantly. Even foreign diplomats were concerned that Bédié's Ivoirité would move the country into the wrong direction.

The French were particular concerned by Bédié's exclusionary tactic directed primarily to Ouattara and other political leaders. On 24 December 1999, a military mutiny of soldiers led to a bloodless coup that ejected Bédié from power without French help to restore order. Their action was limited to camouflaging the deposed president and his families out of the country, first to Togo then to Paris. Meawhile, French interests represented $33 \%$ of foreign investments in Côte d'Ivoire, and 30\% of its gross domestic product (GDP). Since Côte d'Ivoire's independence in 1960, French companies have used one-sided contracts to repatriate $75 \%$ of the wealth generated there. President Konan Bédié, Houphouët-Boigny's constitutional designated successor, tried to correct these anomalies in 1994 by granting coffee and cocoa export contracts to major United States companies, and by licensing another American company, Vanco, to prospect for oil. French interests were threatened in the country, as Bédié openly advocated and 
envisioned to make his country the "Eléphant d'Afrique" (African Elephant) and " $L a$ Locomotive de l'Afrique Occidentale" or West Africa's Economic Engine (Diop 2005). Some analysts have explained the silence of France during the 1999 Coup by this very fact.

Robert Guéi then assumed power for nine months. He publicly announced on national television and radio that he came to clean up Bédié's mess and return power to the civilians. Unfortunately, keeping promises has never been the forte of African military dictators. Instead, Guéï decided to stay in power and ran for the presidency in 2000 against Gbagbo, after Guéi and Gbagbo conspired against Bédié and again Ouattara in the 2000 elections. Mewanwhile, right after the otherthrow of Bédié from power, the junta warned the French government against any attempt to intervene militarily in the internal affairs of Côte d'Ivoire. The new rulers warned that such intervention would receive the appropriate response from the junta, without specifying the nature of the response. Although the French soldiers stationed in Dakar (Senegal) and Liberville (Gabon) were alerted and ready to enter Côte d'Ivoire at any time, the French officials decided not to.

In reality, Guéi was mindful that the French had intervened elsewhere to maintain their influence in the internal affairs of their former colonies in crisis situations. The junta was suspicious that the French military might take advantage of the situation to restore Bédié or put someone else in power. It knew about the cases of Central African Republic, and Camerron (several times). During the junta's nine months reign political, economic, and social conditions in the country worsened. Politically, all the major organizations and parties were silenced. The economy crisis worsened, and foreign aid 
stopped. Police brutality also mounted, while many locals and foreigners who could leave left the country altogether. The tension grew between the France and the junta. It was the first time that France's authority was being challenged in the country and, France tried by any means to retain its influence. Its first move was to cut aid to Côte d'Ivoire. In the end, Guéi himself experienced a failed coup attempt in 2001 that led to the jailing of alleged plotters who happened to be soldiers. After nine months of military government, a popular uprising put Gbagbo in power in 2000. Like Bédié, he attempted to loosen the grip of four French companies. Saur, Electricité de France, Orange, and Bouygues which control transport, water, electricity, and communication respectively on Côte d'Ivoire's economy, three other-Société Générale, BNP Paribas, and Crédit Lyonnais-dominate banking.

When he came to power, Gbagbo began to open markets to international competition in these and other areas (especially to Japan, China, some EU countries, and the United States). When bids were invited for a third bridge across the Ebrie Lagoon in Abidjan, the commercial capital, and for an airport for the coastal city of San Pédro, the tender of Bouygues was significantly less competitive than those from South Africa and China. The discovery of a major oilfield in 1977 at Jacqueville (south-west), near Abidjan, raised the stakes. The exploitation started in 2002. There was suspicion in Paris that Gbagbo was trying to cosy up to the United States. By the end of 2004, the pressure was overwhelming, and Gbagbo announced the confirmation of some French contracts, mainly those from the transportation, energy, communication, and water sectors (Diop 2005: 2) 
During his long tenure as the main opposition leader, Gbagbo had criticized the Houphouët-Boigny regime on many fronts. Specifically, he had been an advocate of free enterprise and economic liberalization. When he assumed power after the chaotic 2000 elections, Laurent Gbagbo realized that he had to liberalize the economy and reduce French domination, which would have helped Côte d'Ivoire to open up to all parties who wished to help improve its economy, and increase free competition for buying of the cocoa, which remained the principal export product. Evidently, France perceived this as a threat to its interests. Intense negotiations (both on the surface and below the table) with the Gbagbo regime did not yield Franco-Ivoirian reconciliation.

The projet de société (governing program) of the Gbagbo regime was called la refondation (refoundation). La Refondation is a nationalist governing method that put the interests of the people over that of France (Koulibaly 2003: 4). Mamadou Koulibaly, a former President of the National Assembly and also an influential member of the Ivoirian Popular Front (FPI), was particularly vocal against French policies of economic and political domination towards the country, especially its previous dealings with the Houphouët-Boigny regime. He was criticized France's insatiable thirst for Ivoirian resources and significant control over areas of development.

Koulibaly has discussed the role of France in the current crisis and its implications. He claims that La Refondation challenges French interests in Côte d'Ivoire, and therefore France is hostile to the Refondation and the Ivoirian leaders who have promoted it.

He notes that the French have multiple interests in Côte d'Ivoire, but they have never keep promises, despite Côte d'Ivoire's sacrifice for its former colonial master: For 
example, France-Telecom benefited from a privatization agreement, which France did not respect. Some contracts obtained by Bouygues over water and electricity under Ouattara's Prime Ministership during the 1990s were not only poorly written, but also poorly executed. Moreover, the famous third bridge across the Ebrie Lagoon in Abidjan priced and does not reflect the guenuine needs of the Ivoirian people. France also wanted to see the north highway project contract go to Bouygue while it sought the rehabilitation of the old railway system ought to be carried out by Bollore (Koulibaly 2003: 4-5). Koulibaly criticizes the Hyazi dossiers and their deceptive multiple accounting techniques, and the CFA itself, whose management is very unfair to Côte d'Ivoire. Koualibaly believed that the current crisis provoked by French interests that do not always respect their engagements, the financiers of this coalition with Burkina Faso against the Gbagbo's regime.

Several other observers have speculated that the chocolate maker, Barry-Callebaut also sponsored the uprising (Koulibaly 2003: 5) As Koulibaly writes: "We must be conscious that Côte d'Ivoire also has some interests that it wishes to guarantee and see respected by all its partners. After this war, the cooperation will never be the same" (Koulibaly 2003: 8). Prime Minister Affi Nguessan also made similar claims on numerous occasions. "We are no longer a French colony and we are asking that France puts an end to its imperial aspirations in Côte d'Ivoire...They [the French] want to absolutely control the commerce of cocoa and coffee which are very lucrative" (Koulibaly 2003: 16)

For Affi Nguessan believed that the crisis in Côte d'Ivoire was due to the fact that the left wing (their socialist friends) is no longer in power in France since April 2002. As 
he puts it: "our problem today is the right wing in France" therefore "our combat is ideological." For Affi, the right wing in France, through their multinationals, are determined to combat the politics of la Refondation at all costs. Meanwhile, in his view, La Refondation advocates the well being of every Ivorian, while the capitalist right advocates only personal interests. (Fraternité Matin 17 July 2003).

Both Koulibaly and Affi, along with the first lady, Simon Gbagbo, were considered anti-French and hardliners of the Gbagbo regime. Koulibaly however tends to dominate the headlines as far as France is concerned. Koulibaly claims that, "The Françafrique is a pact between a French 'mafia' and some African leaders (HouphouëtBoigny, Bongo, Biya, Senghor, and so forth). The French side of this mafia is named la Chiraquie; yesterday it was called the Le réseaux Foccart (Koulibaly 2005: 1)

He goes further to stress that, under the single-party regime, Côte d'Ivoire was managed for the Elysée (French government), and that such arrangements need to be changed (Koulibaly 2005: 2). Under these circumstances the government became a predator toward own population to which it should instead have been accountable. He argues that the complex and discriminatory fiscal system in the country discourages private enterprise and the right to ownership. Everything is state propriety and the state is in the hands of the elite who have organized to steal public goods to the detriment of the citizens (Koulibaly 2005: 3). He also argues that Francophone African elites let themselves fooled. They trusted France, but France does not keep its words or promises. To be sure, France does not respect or honor its international engagements towards African countries. 
The current crisis in which it has played an ambigious role is a case in point. In order to ensure its position of dominanace, France created some so-called "interlocuteurs credibles" on behalf of his ex-colonies, yet the people concerned were never consulted on anything. Finally, France's survival depends on the threat of coup d'etat in the former colonies. Thus, a clear declaration of independence is needed, one that will lead to former metrople and former colonies becoming equal partners (Koulibaly 2005: 4). The frustrations displayed by the Gbagbo regime may be justified, but one should not overlook the fact that there were unforeseable factors, which both France and Côte d'Ivoire did not have control over. This also resonated in the official discourse on either side today. But, what was the aid trend like during the subsequent regions, and especially the Gbagbo regime?

\section{Ivoirian Economic Crisis And French Aid}

In his doctoral thesis (Chapter 4) dedicated to French development aid and reforms of 1998-2002 to Africa, Richard Moncrieff discusses the changes made to the aid relationship between France and Côte d'Ivoire, and the effects of instability in Côte d'Ivoire on French policy. According to this author, Côte d'Ivoire enjoyed multi-faceted relations with France after independence (Moncrieff 2004: 144).

From the mid-1980s this country suffered a thoroughgoing economic and financial crisis, which made it one of the world highest aid recipients at the end of the decade. Under President Houphouët-Boigny (1960-1993) and to some extent the Bédié regime (1993-1999) this country was by far the Francophone African country with most with the most links to France. These two countries nurtured a host of institutional and affective ties and similarities. French aid spending in this small West African nation 
aimed to support this relationship by maintaining French influence at all levels-from French language teaching to Seniors Advisors in the presidency (144).

President Houphouët-Boigny knew that his country could not develop by itself. It needed foreign manpower and capital. He never stopped mentioning the importance and role of foreigners (neighbors and the French) in the development of his country. Speaking in 1957, the President announced the following:

La Côte d'Ivoire ne pourrait pas par elle-même avoir les capitaux necessaries a une expansion à la fois rapide et soutenue. Pendant de nombreuses années elle aura besoin d'une aide en capital suffisamment importante pour permettre à ses habitants de franchir les obstacles sérieux que la nature impose aux pays tropicaux. (Quoted by Bach in Fauré et Médard, Etat et Bourgeoisie...p.90, also Monicrieff 2004: 147)

In general, French aid covered infrastructure projects, the presence of coopérants in ministries, the presence of the military base (not a development aid), and plenty of French language teaching (from 1981-1995, 80\% of 31,000 French were teachers) (World Bank 2001). From 1960 to 1980 France provided more than half net development aid receipts, while Côte d'Ivoire was consistently the highest recipient of French aid. The French filled the capital gap in terms of financial and human resources, necessary for this country's development. The extensive public funds and political stability provided by the French state, as well as Côte d'Ivoire's attractive foreign investment laws, attracted private foreign investment, which dominated the infrastructure, large-scale retail and important sectors (147).

While this French presence must be understood as part of Côte d'Ivoire's development strategy, it was also French policy of deriving commercial and political benefit from close relationships with African leaders. Côte d'Ivoire accepted and indeed encouraged French development aid not only for the technical reasons of development 
financing, but also because Houphouët-Boigny wanted to encourage political alliance between French West Africa and France, an alliance he rightly saw as a guarantee to the stability of his regime (147).

The key to French influence has been the presence of coopérants at very senior levels of government. The French position may be described as "semi-insider". Many of these coopertants have regarded themselves as working both for France and Côte d'Ivoire's government. Relations with France have therefore played a role in the creation of a large technocratic civil service and political class in French education system, civil and military (148).

One major aspect of this relationship was that many French became personally attached to what they saw as the warmth of the Ivoirian society, while many Ivoirians remained drawn to the symbols of “civilization' in Paris. For many Ivoirians the presence of the French was seen as an integral part of the power structures of the Ivoirian society. But, French political culture was not fully implemented. Instead a fragment of French political culture was transplanted in Côte d'Ivoire (149).

Côte d'Ivoire became indebted in the 1980s to both public and private borrowers, incapable of repaying its loans because of a huge fall in the prices of its main commodities (Cocoa and Cofee). In 1987, it announced it could not pay its debts. "The financial crisis changed Côte d'Ivoire relations with donors. Maintaining relations with IFIs became the most urgent issue for the Ivoirian government, leading to the creation of an inter-ministerial committee dedicated to this issue. In 1990s when the IFIs decline aid due to unpaid arrears and blockage in the structural adajustment programs (SAPs), France poured money into Côte d'Ivoire. Around half of the bilateral funds have come from 
France" (Moncrieff 2004: 150). Table 6 below shows bilateral disbursements to Côte d'Ivoire for selective years (in million U.S. Dollar).

Table 6: Amount of Bilateral Disbursements to Côte d'Ivoire By France

\begin{tabular}{|l|c|}
\hline YEAR & BILATERAL DISBURSEMENT \\
\hline 1970 & 53 \\
\hline 1975 & 102 \\
\hline 1980 & 210 \\
\hline 1982 & 183 \\
\hline 1986 & 164 \\
\hline 1988 & 138 \\
\hline 1990 & 554 \\
\hline 1991 & 439 \\
\hline 1992 & 462 \\
\hline 1993 & 768 \\
\hline 1994 & 982 \\
\hline 1995 & 829 \\
\hline
\end{tabular}

Source: Adapted from (Moncrieff 2004: 152)

This table shows a steady increase in French aid to Côte d'Ivoire from the early years of independence until 1995. It also shows that France has always been on the side of the Ivoirian government continuously. Note also that the period covered in this table were the previods under Houphouët-Boigny and partly Bédié, both of whom were PDCI leaders. Finally, table 6 suggests that although Houphouët-Boigny was died, France wanted to not only keep it interests and influence over Côte d'Ivoire, but also its alliance with the old party and the Ivoirian political class. 
In 1994, the devaluation of the CFA Franc was followed by massive development aid transfers, both from IFIs and France to alleviate the country's immediate balance of payment and debt problem. The massive rise in disbursements by the IFIs was regarded as a reward for the devaluation. The year 1994 and 1995 saw a series of new loan agreements, including a three-year Enhanced Adjustment Facility (ESAF) loan agreed by the IMF in 1994. The growth of the Ivoirian economy was impressive in 1995-1998, although the debt burden remained massive (153).

The French were of course aware in the early 1990s not that the scale of the financial crisis of Côte d'Ivoire was beyond their means, but also that the political and social model they had helped set up was fracturing. Although increasingly worried by the emergence of a xenophobic political discourse after Houphouët-Boigny's death in December 1993, and especially surrounding the elections of 1995, the French in fact had little option but support to Bédié, and try to use behind the scenes influence to moderate political dialogue (Moncrieff 2004: 153).

During that time, The Ivoirians habitually came to the French for financial help and, through the Elysée, and the Cooperation Ministry, tried to use historical and personal influence to persuade the French to bail them out before going to the Inteernational Monetary Find and World Bank. The practice was stopped or seriously curtailed by the Abidjan Doctrine of 1993. In terms, the IFIs-led reform agenda, France played an ambivalent role. With pressure mounting and crisis growing, the French tried to cajole the Ivoirian officials in implementing reform, so Côte d'Ivoire can avoid adopting all the conditionalities (Monicrieff 2004: 154). 
The first concrete reform between France and Côte d'Ivoire was the "Commité Mixte" of December 1998 (to discuss aid relations). The Commité Mixte involved meeting with the non-governmental sector, and the Ivoirian officials, the results were then fed into the main conclusions. The second aspect was the demise of the rapport de Commité Mixte, which lays out French intensions, and signed both parties (protocol d'accord on aid). The Rapport was replaced by the Document Cadre au Parténariat au Dévélopment (details mutual obligations, French cooperation to Ivoirian policies and initiatives) (Moncrieff 2004: 155)

1998-99 was a period of increase emphasis given to cooperation with NGOs and local government. In the agriculture sector, for example, French support aimed at creating, financing and supporting professional organizations (unions and cooperatives) to replace the state marketing system. In the health sector, the making of a non-profit medical cooperative away from government control and near the people it is intended to. French also created some pilot projects throughout the country (for instance, Man in the west). The Fond Social Au Dévéloppement (FDS) was created to work closely with local populations in small-scale projects. The French insisted foreign aid must support Ivoirian citizens, and local government policies, but not government initiatives. This happened during much of the 1990s aid from must donors. But, some of these projects have not yet been implemented since 1998, probably because the French want to excercise oversight on all the aid given (158).

There are indications that the development of aid relationship between France and Côte d'Ivoire was facing some serious problems in 1998 and 1999. The Ivoirian government failed to implement these policies, either for lack of political will, or its 
inability to carry out such policies alone, signaling it over-dependence on French assistance. In 1998, frustration started to grow on the French side, for the Ivoirian government unwilling to implement administrative reforms, and massive fraud within the Ivoirian administration (160).

Frustration became greater in 1999 as Côte d'Ivoire's economy was going under and it was unable repay its arrears to donors. These problems were exacerbated by the difficulty relationships that existed by between the Bédié regime and French Socialist adminitration. Note also that the visits to Côte d'Ivoire of Josselin in July 1997, and Vedrine in October 1997 were dominated by public and media discussion of France's "abandoning" Africa, and scale down support for African regimes, starting with the PDCI (160). 1999 was clearly a period of tension in Franco-Ivoirian relations, culminating in Josselin's public rebuke to Bédié over the jailing of opposition RDR members, which Josselin stated, would inevitable damage Franco-Ivoirian relationship, (AFP 17 November 1999, and Moncrieff 2004: 161).

\section{Ivoirian Political Crisis And French Aid}

In December 1999, Bédié was overthrown. The French decided not to intervene, nor they had demanded that Bédié and the PDCI be restored to power. The French believed that Guéi would keep his promise to hold democratic elections and give power to the civilians (Moncrieff 2004: 161). In 2000, law and order, state finances, and public administration disintegrated. Ouattara and Bédié had been excluded from running, leaving Guéi and Gbagbo as the sole vital candidates. The French and EU supported the referendum, but suspended aid when ouattara was excluded. Gbagbo won the elections after Guéï tried unsuccessfully to hijack the process by force (Moncrieff 2004: 162). 
Also, in 2000, the French stated their intention to suspend the aide souveraine or (sovereign aid) that directly supported the Ivoirian state, as well as military cooperation except aviation security and plan for a regional peacekeeping training school for the Ivoirian military. Most of French coopérants working in central ministries were withdrawn. The French instead continued aide de proximité that benefited the people directly. The Coopérants in these areas were maintained in place (Moncrieff 2004: 162). According to Moncrieff (2004), some projects were suspended during much of 2000 because of suspension of cooperation with the Ivoirian state (for instance, military training, fire training). Some projects were not suspended but their operations were impacted/showed by the security conditions on the ground or government was broke. Evaluation visits and training sessions were cancelled. In some instances the French would impose conditions to either re-start or assured the personal security of French personnel. Several projects were divided into sovereign and proximity components, while some sectors were either unaffected or positively encouraged (for instance, funding of small-scaled projects)

The election of Gbagbo delighted many in the socialist camp in Paris, with which the FPI clearly identified. Note that the French Socialist Party supported Gbagbo during his tenure in position. The French quickly approved Gbagbo despite Koffi Annan's statement that the elections were not legitimate. By-mid November 2000, Paris was swinging to support the new regime in Abidjan. Unfortunately, Franco-Ivoirian relations were gradually improving when the controversial 2000 legislative elections of December took center stage, creating frustration in Paris. 
These legislative elections led to the repression of Ouattara's supporters who took the streets to demand justice. From 2000-2001 the French looked at restarting their aid spending. Meanhile, the coup December 1999 coup accumulated more arrears. In 2002, Côte d'Ivoire stopped making any payments on its arrears. As Moncrieff writes: "On the bilateral front, what stands out in the eighteen months following the election of Gbagbo is a combination of support and misgivings... In a sense France has done the impression as if whoever comes to power in Abidjan would be welcome" (152).

The French adminitrations of Chirac and now Sarkozy have tried to hide their resentment for the socialist regime in Abidjan. One element of this new relationship is that both sides have been vocal on numerous issues, carried out by their respective media outlets. France has been frustrated by two things: First, the Gbagbo regime his expected role of "good student" of France as did the first regime. Second, despite all the problems, gbagbo remain popular, and any attempt by France to undermine his regime will cause chaos on both sides. Though, it did receive some important aid package, the gbagbo regime has looked elwhere for help, which threatens French influence and authority in Côte d'Ivoire. In sum, France did provide limited aid to the Gbagbo regime, and it assisted it in negotiations with the IFIs. At the same time, France has shown some hostility towards the Gbagbo regime over elections matters, and especially Ouattara. Since France has shown its support for Ouattara, it could be argued that also encouraged the rebels to go ahead with their initial plan. What were the relations of Côte d'Ivoire with its neighbors like? 


\section{Côte d'Ivoire's Relations With Its Neighbors}

Côte d'Ivoire borders Liberia and Guinea-Conakry in the west, Mali in the northwest, Burkina Faso in the north, and Ghana in the east. These countries belong to a series of important regional and continental organizations since the indepdence era including: the Banque Centrale des Etats de l'Afrique de l'Ouest (BCEAO), and Organization Commune Africaine et Malgache (OCAM), and the Organization of African Unity (OAU), now African Union (AU) which was not a high priority for on President Houphouët-Boigny's diplomatic agenda. In fact, his record was marred by poor attendance or threats to boycott summit meetings, as well as disregard for its decisions when they differed from his own, for example, his recognition of the Biafra, which wanted to secede from the Nigerian State, and his position on dialogue with South Africa (Toungara 1990: 47).

Nevertheless, Houphouët-Boigny was frequently consulted as the elder statesman by his neighbors on development issues, as Côte d'Ivoire was a very important economic engine in the region. Even the most revolutionary leaders (for example, Thomas Sankara of Burkina Faso, and Jerry Rawlings of Ghana) that emerged as a result of a coup d'etat have traveled to Yamoussoukro to consult with the 'Old Man”' (Toungara 1990: 48)

The president had generously offered Ivoirian hospitality to more than one deposed African leaders in Côte d'Ivoire, notably Odumegwu Ojuku and Jean-Bedel Bokassa, as well as the Maurice Yameogo of Upper Volta (now Burkina Faso) (Jeune Afrique 1 July1987: 28-32). Under Houphouët-Boigny, Côte d'Ivoire was frequently cited as an example of what Africans are capable of achieving through a stable political environment with a liberal investment policy. His ascendance to global importance, as an 
official spokesman for African affairs, was largely the result of his triumph of political tactics consisting of persuasion, negotiation, and reconciliation (Toungara 1990: 52).

He had maintained a policy of openness and brotherhood that made it difficult for his foreign enemies to intervene negatively in his country. In particular, the open door policy to immigrants during the first decades of independence was important to this regional solidarity with the neighbors, and the rest of the continent. It could also argued that the strong French presence and interests in the country constituted a strong deterrent for would-be-trouble makers a home and across the borders. As leadership changes, with mounting problems, the relationships between Côte d'Ivoire and its neighbors gradually started to deteroriate. Generally speaking, Côte d'Ivoire and its neighbors have lived in a relative peace, and almost perfect harmony with each other. Though, they have sporadically been involved in each other trouble either directly or indirectly. As a result of this, tensions have rising between some of them. For instance, Côte d'Ivoire and Burkina Faso were involved in the Liberian war of the 1990s. The latter was also accused to have participated in the war in Sierra Leone alongside their Liberian counterparts and Foday Sankoh. Another example was the violence between Ghana and Côte d'Ivoire following a soccer game in Ghana in which Ivoirian supports were attacked in Ghana. When the story broke Ivoirian took the street and attack many Ghanaians living in Abidjan and elsewhere in the country. Several Ghanaians lost their lives in this incident. But, relations between these neighboring countries have varied over time.

Côte d'Ivoire-Ghana relations had varied since independence. For instance, when he assumed power, Côte d'Ivoire regarded the government of Flight Lieutenant Jerry Rawlings, who overthrew a civilian regime in 1983, with a mixture of disdain, contempt, 
and wariness. Relations with Ghana declined in the mid-1980s after Rawlings and Burkina Faso's leader Thomas Sankara appeared to ally themselves with Libyan leader Muammar Qadhaafi. In November 1987, Ghana condemned Côte d'Ivoire for granting landing rights to South African military and commercial aircraft, undermining Organization of African Unity (OAU) resolutions, isolating Burkina Faso in West African Councils, and permitting Abidjan to become a haven for hostile South African, Israeli, and Western intelligence services. At the same time, the two states worked together harmoniously to end smuggling in both directions across their common border. In general, the two countries have remained close to one another. In fact, most people saw President Kuoffor a friend and ally of President Gbagbo during the crisis. As for the Ghana state, it was seen as a peaceful neighbor that commanded much respect.

Relations between Côte d'Ivoire and Burkina Faso has been fascinating and special one. Note that the two countries used to be united as one. The northern part was called Upper Volta, while the south was named Côte d'Ivoire. Therefore the two countries share a lot in common, including culture, history, and territory. Because of these facts and other matters, president Houphouët-Boigny had accorded this country a high level of consideration. His open door economic polivy benefited this country very much. So that he was willing to make political sacrifice and concession on its behalf. As Moncrieff (2004: 145) writes:

In 1964, Houphouët-Boigny proposed a law that would have given nationals of Haute Volta the same right to public employment as Ivoirian nationals. "The PDCI successfully resisted to this. However, Houphouët-Boigny did give the foreigners the vote in the one-party system, although it was taken away under pressure from some factions of his own party and the opposition FPI who, aware that many foreigners felt $\mathrm{s}$ strong allegiance to Houphouët-Boigny, accused him of using them as "electoral fodders." 
Burkina Faso has served as a reservoir for agricultural labor. The first tensions rose when Thomas Sankara took power by force in August 1983. The young leader joined with another yound military leader on the other side of Côte d'Ivoire, thus, creating fear in Abidjan. Tensions between Côte d'Ivoire and Burkina Faso increased sharply in early 1985 following the alleged mistreatment of Burkinabé immigrants in Côte d'Ivoire and the assassination of a prominent Burkinabé businessman in Abidjan. In September 1985, hours before Sankara was to arrive in Côte d'Ivoire for a Council of the Entente summit meeting, a bomb exploded in a hotel room he was to occupy. Sankara blamed forces in Côte d'Ivoire, although no one claimed responsibility and no one was arrested.

In October 1987, Sankara was killed during a coup led by his second in command, Captain Blaise Compaoré. Compaoré immediately reassured Côte d'Ivoire that he wanted warmer relations and later pledged to strengthen ties with the Council of the Entente countries. For its part, Côte d'Ivoire reaffirmed its "readiness to engage in trustworthy, brotherly, and lasting cooperation with this neighboring and brotherly country. But, tensions emerged again in between 1993-2002. Many Burkinabès were expelled from their plantations by local Ivoirian planters in the western coffee and cocoa belts. Worse, because of the installation of identity cards, and their alleged support for Outtara, these people were brutalized and constantly harrassed by the security forces. Many who feared for their lives left the country. Finally, it was alleged that the current rebellion had trained in that country before the attack of 19 September 2002. Fortunately, the intervention of President Compaoré as a major power broker between the rebels and the Gbagbo regime has help calmed both sides. 
Côte d'Ivoire and Guinea-Conakry have had their time of discord, especially during the civil war, which saw many people from the west and north crossing the borders to safety. Guinea-Conakry feared the spillover effects of the war in Côte d'Ivoire. But, it has not been accused to be involved in the current crisis. In the past however, these two countries have had their own dislike in 1958 translated by the opposition between President Sekou Toure and President Houphouët-Boigny over local matters, and French influence in the region. When Toure died Ivoirian relations with Guinea improved considerably. And it has remained that way for a long time.

Relations with both Mali and Liberia, although far from warm, were decidedly less confrontational than those with Guinea, Burkina Faso, and Ghana. Bamako has remained a good friend and neighbors of Côte d'Ivoire (at least officially) until the war impacted his citizens living in Abidjan and elsewhere in the country. Liberia has been a good neighbor until it started to experience its own civil war in the 1990s. As mentioned above, because personal ties with the leadership, President Houphouët-Boigny decided to get involve. When the civil war broke in Cote d'Ivoire, the Liberian fighters joined the MPIGO and MJP against the Gbagbo regime. Since, the countries have looked at each other with some reservation.

It should be noted that so far, only Mali, Burkina Faso, and Liberia were cited as participants in the war. Mali was accused of providing the MPCI Dozo fighters (cast of traditional hunters). Burkina Faso was also accused for allowing the rebels to train in the Po region. But, such allegations have been diminished since President Compaoré started his role of "bons offices" to help resolve the crisis. As for Liberia, it remains a good neighbor despite the intrusion of mercenaries from there. If any of these countries 
decided to get involved, it is because they felt insecured, as Côte d'Ivoire represented absorbs a huge portion of their population, and contribute to their own economic survival. Under the first regime they were kept politically satisfied. But, the crisis could have started under Bédié or Guéï as well.

From the above discussion, one can argue that Côte d'Ivoire's foreign policy towards its neighbors has varied over time because of the simple fact that the changes in the leadership, and the new global context. The Bédié, Guéï, and Gbagbo regimes seemed to have been overwhelmed by the internal demands of the Ivoirian polity, so that they did not really have enough time to develop and expand a clear foreign policy agenda. For instance, since it came to power, the Gbagbo regime's main concerns have been about mainly regime security and little anything else. Bédié's reign was rather short and marred with legitimacy problems. Guéî's nine months occupation was a complete disaster, both internally and externally. To this end, we can say the regional political context was an empty one after Houphouët-Boigny. 


\section{CHAPTER 6}

\section{CONCLUSION}

My dissertation was interested in understanding the root and proximate causes of the civil war that broke out in Côte d'Ivoire on 19 September 2002. In other words, it sought to understand how one of Africa's most stable and prosperous states had fallen victim to war. The central question of this study was: Why did Côte d'Ivoire, which was relatively stable under President Houphouêt-Boigny, suddenly begin to experience political violence in the 1990s and an explosion in $2002 ?$

Chapter one outlined the entire dissertation project, and contextualized the analysis that followed in the subsequent chapters. The first section described the long period of relative political stability and economic success under President HouphouëtBoigny. The second section gave a thorough account of the events that led up to the civil war on 19 September 2002 then it discussed why the war began.

Chapter two reviewed the literature on civil wars in general, identified the different types of civil wars, then it discussed the nature of the Ivoirian civil war in light of these typologies. The chapter also included a discussion of the cultural pluralism versus political economy approaches; domestic (social depravation and resources opportunity) versus international political economy approaches (structural adjustment programs); international pressures approaches (including Western pressure for democratization, patron-client relations with France, and French pressures), and regional pressures from neighboring states such as Liberia, Mali, and Burkina Faso.

Chapter three examined the domestic and international political economy as a source of civil violence in Côte d'Ivoire. First, it sought to know whether the civil war 
began because the population got poorer during the 1990s, and "angry young men" become available and willing to fight. In other words, did the socio-economic grievances stimulate the fighting? The study found that poverty was already spreading across Côte d'Ivoire even before the 1990s, as a result of declining commodity prices that resulted in a huge economic contraction, high unemployment rate, company closures, massive layoffs, huge internal and foreign debts, rising costs of education and living, shrinking middle class, food insecurity, and falling life expectancy, among other things. In other words, the socio-indicators were very low across the board. The crisis became even more pronounced with the imposition of IMF and World Bank austerity measures (also known as SAPs) that led to the devaluation of the CFA Franc in 1994. The study suggested that had the general misery been a major contributing factor, the war would have been started long before 2002, perhaps, under the Bédié regime.

The study also explored whether the rebel recognized an opportunity to take control of the country's economic resources for their own benefit. It found that the control of resources was not a part of the initial plan set forth by the rebels. Their main goal was to overthrow the Gbagbo regime in Abidjan (south). When they failed to do so, they retrenched themselves in Bouaké (center), Korhogo (north), and parts of the West, where they established their headquarters. The rebels occupied more than a half of the country, and started using the resources under their control to sustain their movement. Note that an international peacekeeping force made up of the French Licorne, ONUCI, and ECOWAS forces served as a buffer zone to prevent the rebels from advancing toward the capital, Abidjan. 
Meanwhile, there were reports that the rebels had broken or vandalized BCEAO banks in Bouaké (center) and Korhogo (north) during the first weeks of the uprising, and steal an undisclosed amount of cash. The rebels also exploited the natural resources (diamond and gold) and agricultural commodities (coffee and cocoa) under their control. Koné Zakaria, a MPCI leader in the northwest region (Séguéla and Mankono) was accused of illegally exploiting the diamond and gold for his own benefit. It could be argued that the economy did not play a significant role in starting the war, but it proved important thereafter to sustain the rebellion.

Chapter four discussed the role of ethnicity and region as identities of the civil war in Côte d'Ivoire. In other words, it sought to understand whether the civil war was essentially a war between different ethno-regional groups in the country, and not about economics. A review of the internal composition of both the national and rebel forces indicated that the three rebels groups (MPCI, MPIGO, and MJP) were dominated by one or two major ethnic groups. In fact, their declarations during the first days of the crisis confirm this.

The MPCI led by Guillaume Soro (a Senufo from Korhogo) claimed to be from the north. Many of Soro's lieutenants and followers included many northern Dyula or Malinké. But, there were significant numbers of non-northerners also. This was the case of Dakouri Tabley and Alain Lobognon, both Bete from the center-west, and Michel Gueu, a Guere from the west. The MPJ and MPIGO were predominantly ethnic based also. These rebel groups were led by Guere and Yacuba leaders who wanted to avenge General Guéï, assassinated on the night of the uprising in Abidjan. The majority of their members were also from the same ethnic groups, who fought alongside several 
mercenaries from neighboring Liberia. The chapter concluded that the three rebel forces were highly ethnic-based.

A similar argument was made about the National Armed Forces of Côte d'Ivoire (FANCI) also. Though, the FANCI have suffered serious internal divisions because of political manipulations. The Bédié, Guéï, and Gabgbo regimes all manipulated the FANCI in order to accommodate or consolidate their power. For example, Bédié had replaced General Guéï with General Doué, while Gbagbo replaced General Doué with General Mangou. Other security organizations such as the Garde Républicaine, Gendarmérie, and Police also experienced a change of leadership. The chapter concluded that the civil war in that country is one that involved different ethno-regional groups over power matters, and not primarily about economics.

Chapter five analyzed the role of the foreign relations in the civil war, as well as the regional political context. It was interested in finding out whether the war broke out because France was hostile to the Gbagbo regime in a way that it was not hostile to the regimes of Houphouët-Boigny, Bédié, and Guéî? If yes, did French aid fall after Gbagbo's election in 2000 ?

The study argued that Houphouët-Boigny was a very charismatic leader with tremendous credentials and respect, and more importantly a historic servant and key ally of France since the colonial era. Thus, he fully benefited from the French, including protecting his power. Such relationships were altered during the subsequent regimes, thus a change in France's attitude towards the subsequent regimes, including the Gbagbo regime. 
When he came to power in 1993, Bédié tried to alter the existing relationships that Côte d'Ivoire had with France, which, according to some, cost him his presidency. To be sure, France did not activate the security and defense treaties the two countries had signed since independence, after he was ousted from power by the military in December 1999. Instead, France contented herself with smuggling him out of the country, and offering him and his family asylum to Paris. Bédié was also accused of being arrogant, and neglecting Houphouët-Boigny's heritage.

Once he assumed power in December 1999, Guéï attempted to defy the authority of French government, he demanded that France stayed out of the crisis, that any interventions by the France forces would be risky and unwise. He also tried to suspend the servicing of all the foreign debts incurred before him, especially by the Bédié regime. But, under huge pressures from France, the European Union, and other aid agencies, he was forced to change his mind. Guéï was also perceived as arrogant and uncooperative.

Finally, Gbagbo came to power determined to implement his new socialist political agenda, "La Refondation," a system of governance that favored national interests over foreign ones. In other words, he insisted that the resources of Côte d'Ivoire must benefit its people (not foreign companies or some imperialistic powers). Furthermore, he vowed to open the Ivoirian market to all foreign competitors that wanted to do business with his country. Thus, his administration tried to revise some of the special or sweet deals Côte d'Ivoire has had with France for decades, mostly through its companies which dominated vital sectors of the country's economy. Obviously, France did not like these changes, this was a threat to its vital national interests, not to mention an insult to French's self-perceived role in that country. 
When the war broke out, a number of things occurred that helped explain France's attitude against the Gbagbo regime. For example, France was quick to declare that the war was an internal affair in which it could not get militarily involved into. Also, during the Linas-Marcousis summit, and after former FPI Prime Minister Affi Nguessan lost his post to Seydou Diarra, the French government tried to take away key ministries (for example, Defense and Interior) from the Gbagbo regime and have them accorded to the rebels in an Ivorian unity government.

France's attitude toward the subsequent regimes (1993-present) in Côte d'Ivoire has been to pull back and observe, ignore, or step in when the situation has become chaotic, to use its influence and obtain what it wanted, demonstrated by the initiation of all the UN resolutions on the crisis in that country. When the situation started to improve, the first action from France was the historic visit of Le Patronat Français (business class) to Côte d'Ivoire, allegedly to negotiate or re-negotiate new and old deals with the Gbagbo regime. The chapter found, however, that the relations between France and her ex-colony remained poor because of all these policies set forth by the new Ivorian leaders against French interests in the country.

Chapter six presents below all the arguments developed throughout this dissertation, distinguished between superficial and deep causes of the Ivoirian civil war, and made judgments about the relative weight of the various causes, including the extent to which the weight of the causes can be measured. That is, is it possible to give an empirical answer to the question of why the war began? Can one explain the war, and demonstrate with scientific precision which causes were primary? Or can one only understand the outbreak of the war in the manner an anthropologist understands a 
culture? Finally, what does the comparative evidence from other wars that began under similar circumstances, as well as peaceful political reform efforts that did not lead to war, have to tell us about the Ivoirian war?

\section{A. Distinction Between the Root and Proximate Causes of the War}

The Governance and Social Development Resource Centre (GSDRC 2006)

provides a comprehensive list of causal factors that fall under six broad categories

including: Inequality (political, economic, social, and "grievances"); identity

(mobilisation of groups with shared ethnic or religious identities); political factors (crises

of state legitimacy, and weak state institutions); economic factors (economic motivations

for engagement in conflict, and "greed"); political economy (where access to resources is

determined by violence); and international factors (trade, regional instability, and

development assistance). According to this institution, "it is generally agreed that none of these factors caused the war, but it is the dynamics, or interplay, among the factors that leads to violence."

Roubeaud (2003: 57) has done a good job grouping the different causes scholars have attributed to the war in Côte d'Ivoire into two analytical categories. He calls them the economic and political explanations. As he beautifully puts it in his native French:

La plupart des analyses de la crise Ivoirienne se déclinent suivant deux lignes d'interpretations, qui, selon les auteurs, peuvent être plus ou moins combinés ou exclusives: D'un coté, une explication met en avant des facteurs de type économique. Près de deux décénnies de crise et d'adjustement structurel ont conduit à l'effondrement des équilibres antérieurs, sans faire émergence de solution alternative viable: appauvrissement généralisé, déstabilisation, des réseaux de solidarité familiaux et communautaires, épuisement de la rente foncière, libéralisation sans remise en question des logiques rentières, démentèlement de l'état et tarissement de la rédistribution. Une autre explication privilégiée, la piste politique tourne autour des réalités pour la succession de Houphouët-Boigny à la tête de l'état depuis les années 1990. Les conditions d'éligibilité, le code de la nationalité, les cartes de séjour, ou le code foncier, 
questions autour desquelles le conflit s'est cristalisé, ne sont que des armes forgées et instrumentalisées par las quatres prétendants présidentiels (Bédié, Ouattara, Guéi, Gbagbo) et leurs clans respectifs dans leur lutte acharnée pour le pouvoir (Coulibaly 2003). Dans tous les cas, la boite de pandore ouverte et theorisée avec le concept d'ivoirité joue un rôle pivot dans la montée des tensions.

Roubeaud's work is a goos start to understanding the origins of the Ivoirian crisis. But, in order to fully determine the actual root and proximate causes, it is important to provide a brief definition of each type of causes.

Root causes of conflict are social realities that have developed over a considerable period of time and that remain unresolved. These causes can be dormant for a short time or long time depending on their effects. Once they increase in numbers or magnitude, they can often lead to the outbreak of serious conflict situations in a dramatic fashion. An example of this is the long humiliation and discrimination against the indigenous Liberians by so-called Americo-Liberians, which resulted in fierce battles between the Khran, Gio, Mano, and Mandingo tribes in the 1990s.

Proximate causes are typically the triggers of socio-political conflict. This may be a single, or combination of factors, that cause different groups to go war with one another. These causes are also the limit, intolerable level, or break point that a victim can take or endure. Therefore, something must be done about it. For example, the genocide in Rwanda of the 1990s was triggered by a single event, the downing of President Habyariman's aircraft in April 1994. That event was the pretext used to start the mass murder that took the lives nearly 800,000 people, though the cause of the plane crash itself remains a matter of controversy. The above definitions suggest that all conflicts have root causes, but these causes are often overshadowed by more visible ones that are 
used as the pretext of the belligerents to go to war. In that sense, the war in Côte d'Ivoire is no exception.

In the Ivoirian case, the root causes include: (1) The economic crisis of the early 1980s due to the fall of Côte d'Ivoire's main commodity prices on the world market, (2) the end to the one-party system and the death of President Houphouët-Boigny in December 1993, (3) the change in the Franco-Ivoirian relations following the same event, (4) the weakening state institutions and state legitimacy, (5) and the absence of sound immigration policies.

As for the proximate causes of the Ivoirian war they include: (1) The Ivoirité concept used by leaders to manipulate the political process, (2) the controversial presidential elections of 1995 and 2000,(3) and the harassments and abuses perpetrated against northerners and certain immigrant communities. The relative weight of these root and proximate causes is assessed below.

\section{B. Judgment About the Relative Weight of the Various Causes}

\section{Relative Weight of the Root Causes}

The economic crisis that Côte d'Ivoire had experienced since the late 1980s was due in part to falling prices on the market of its main commodities (coffee and cocoa). In order to rescue it from plunging further, the international financial institutions imposed several adjustment programs during the 1980s and 1990s. Unfortunately, these adjustment programs did not yield the expected results. This resulted in rising poverty and unemployment. The social indicators during that time revealed a significant drop in the living standards across all the social layers. The 1994 devaluation made matters worse, and consumer goods became more expensive or even unaffordable for many 
Ivoirians, resulting in a huge dissatisfaction among the people, and the government was unable to provide any help. The situation deteriorated even further under the nine months of military rule, and it did not improve before President Gbagbo took power in 2000.

The economic crisis did impoverish a huge segment of the Ivoirian population, resulting in the loss of confidence in the government. When things were better, the government was able to keep the people generally satisfied for a long time. But it has been demonstrated in this dissertation that the rebels'original plan was not to acquire wealth or control resources; therefore it could be argued that the economic crisis did not play a significant role in the civil war in Côte d'Ivoire.

Second, there was the death of President Houphouët-Boigny and the consequences of his demise. For better or worse, Houphouët-Boigny was considered a charismatic leader and great politician by many standards. He was considered the main architect of the initial impressive economic success and relative stability. Le Vieux (old man) was also a unifying force. Throughout the three decades of his personal rule, he was able to maintain all the communities together by creating a discussion forum, which he had often used to address the nation during times of crisis (Le Dialogue). HouphouëtBoigny was very inclusive in all his speeches, and he often adopted a paternalistic tone including this one:

You are all my brothers, my sons, and my grandchildren; good or bad, you are all my brothers, my sons, and my grandchildren. And for my part, I consider you all to be good brothers, good sons, and good grandchildren. Therefore, have confidence in me (Africa Report, Jan-Feb 1983: 5)

He also created "La Démocratie à L'Ivoirienne" (Ivoirian Democracy) whereby all the major ethnic groups and communities were represented, not only in the various 
governments, but also in the army, gendarmerie, navy, and police. Similar appointments were done for the district administrators known as prefets and sous-prefets around the country. Furthermore, the president included all the Customary Chiefs in the affairs of the state. All these political maneuvers and other qualities kept the majority of the people politically satisfied, thus less prone to rebel against the system. After Houphouët-Boigny died, this precious heritage was neglected. His passing disrupted the social fabric of authoritarian unity, which had been a significant contribution to the social peace. This idea is further developed below. But, Houphouët-Boigny was also a key ally of France since the colonial era. As a result of this alliance, he had the full backing of the French should any turmoil occur internally or from outside the country. In fact, the impressive French military presence in Abidjan was an obvious sign of this, that is, a good deterrent for potential troublemakers.

These Franco-Ivoirian relationships suffered a big blow, first under Bédié, then Guéï, and Gbagbo. These individuals had different personalities and relationships with the French "Empire." Although Bédié had been groomed to carry them along, he obviously missed the opportunity to do so. Their political visions and agendas were different than those of Houphouët-Boigny. Note also that the new globalization imposed new dynamics in Sub-Saharan Africa, seriously undermining the old patron-client relationships from which Houphouët-Boigny and the PDCI had benefited so much for nearly four decades.

Under Houphouët-Boigny's regime, France's interests were almost fully guaranteed, whereas this was not the case under the subsequent regimes. France then adopted a different attitude toward these leaders, their associates, and the country as a 
whole. In fact, France could have foiled both the coup of December 1999 as well as the September 2002 attack by providing at least some important intelligence, and other forms of support. But it did not, signaling the rebels their action would suffer no interference from France. In sum, the Franco-Ivoirian relations did play a significant conditioning, or enabling, role in the crisis.

The fourth root cause of the Ivoirian war was the weakening of the state institutions, and thus the legitimacy of its leaders. Democratization brought many institutional changes with it. The political culture, however, did not change to accommodate the new context. Upon Houphouët-Boigny's death in December 1993, Article 11 of the state Constitution automatically allowed Bédié (then President of the National Assembly) to take over the president's mandate. Despite these arrangements, Ouattara decided to interfere. After losing to Bédié, Ouattara made several incendiary comments and declarations that continue to define his political standing to this day. Because of these comments, many people considered him the "father", "sponsor", or again "mastermind" of the December 1999 coup, as well as the September 2002 attack against the Gbagbo regime. These animosities also led to sharp divisions between the Bédié regime and Ouattara supporters.

In 1995, Ouattara was banned from running in the elections. Bédié easily won 95\% of the votes. In 2000, Guéi also excluded both Ouattara and Bédié from running, and then he tried to steal the elections from Gbagbo. After the passing of President Houphouët-Boigny, the new leaders manipulated the political process for their own advantage, disregarding the laws of the nation. In sum, the flawed institutional 
arrangements, repressive and corrupt security forces, and the inability of the leaders to address the countries problems contributed greatly to the crisis.

The fifth root cause of the Ivoirian war relates to the absence of sound and clear immigration policies. Since the early years of independence, President HouphouëtBoigny had opened the doors to many foreign nationals to participate in the booming economy, and thus, Côte d'Ivoire gained a reputation as a highly hospitable country, and the economic engine of West Africa. This also led to the recruitment of many foreign educators from Benin, Togo, Senegal, and France into the public service (for instance, in education, health, and administration). The agriculture sector saw a boom in the 1970s and part of 1980s thanks to thousands of foreign workers from neighboring Mali, Burkina Faso, Guinea-Conakry, and Niger.

Unfortunately, this open-door policy flooded the country with immigrants whose number remained unchecked over the years. A huge number of people fleeing from natural disasters zones (droughts, famines, or floods), and wars in other African regions migrated to the country. By 1990, Côte d'Ivoire realized it had an immigration problem, which it had longtime denied. When the economic crisis reached its pick (also rampant insecurity) immigration became central in the national discussion. The majority of arrested criminals were alleged immigrants from the countries mentioned above. Thus, began the harassment of the various immigrant populations, justified by the adoption of the carte de séjour invented under Ouattara's adjustment plan.

Meanwhile, in the western cocoa and coffee belts, Malians and Burkinabès saw their plantations taken away, destroyed, or burned down, and had to flee for their security. They were thoroughly vilified by indigenous Ivorian populations. Like Ouattara 
in 1993, they also were told they did not belong in the country. In retrospect, it is clear that these poor immigrants have consciously or unconsciously supported Ouattara for this reason. These immigration, land tenure, and citizenship problems were created under the first post-Houphouët regime, but they were not properly addressed by the subsequent regimes either. Nonetheless, though this may have generated tacit support for the rebels from certain members of these immigration communities, immigration was not a significant factor in the war that broke in September 2002.

\section{2-Relative Weight of the Proximate Causes}

The democratization process of 1990s brought significant changes to Côte d'Ivoire. Not only it did allow competitive elections, but also renewed interest in the political game after nearly four decades of one-party system. It also created a new political culture, thus new attitudes, behaviors, and aspirations among the people. While the new context created new opportunities for the opposition parties, it seriously disrupted the old regime, which has yet to recover from this. The PDCI has been weakened significantly because of internal dissidence. Some of its former members have created new parties, and made alliance with the Gbagbo regime. As in many countries in the developing world, multipartyism in Côte d'Ivoire has brought more tensions and divisions in the population. Party leaders have often made alliances that they could not keep because of greed or power struggle. For example, Ouattara and Gbagbo had formed the Front Républicain (republican front) against Bédié. The same Bédié is now allied with Ouattara against Gbagbo under the banner of the infamous (Rassemblement des Houphouetists, or RHDP), which by the way, is on the brink of explosion as each candidate seeks to position himself for the next persidential elections. It should be 
emphasized that this odd pattern (alliance then betrayal) has dominated Ivoirian politics since the death of President Houphouët-Boigny in 1993. It is in part the new political context, which these leaders have manipulated for their own individual gain that triggered the war. The next two proximate causes are directly linked to this one.

After he became aware of Ouattara's ambitions for the presidency, Bédié did all he possibly could to stop him. First, he used legal means by refusing to recognize Ouattara's alleged "forged" Identification certificate he had obtained in Dimbokro (center) that stated that he was born there in 1942. Bédié also invented (though others exploited it as well) the powerful and infamous "Ivoirité," in which he viciously attacked Ouattara and his alleged Burkinabè origins. As time progressed, the "Ivoirité" concept that was designed to counter a political enemy (Ouattara) in the first place, became a slogan, and also political weapon against both immigrant communities and northerners. These communities saw in Ouattara an icon, representative, leader, and spokesman. The civil war of September 2002 is the direct consequence of the Ivoirité movement created by Bédié and also exploited by all the subsequent regimes. In other words, these communities were tired of being relegated to second-class citizens by the Bédié, Guéi, and Gabgbo regimes. The Ivoirité was by far the single most important factor that triggered the civil war in that country.

The 1995 and 2000 controversial elections have much more in common than they have differences. To be sure, in 1995, Bédié won $95 \%$ of the votes against very weak opposition candidates. The 2000 elections that put Gbagbo in power had a very low turnout of voters, though they did put an end to a ruthless nine months military rule. In 2000, Guéi excluded both Ouattara and Bédié to run alone against Gbagbo. Another 
important similarity was that each time Ouattara' supporters demonstrated against these injustices they were heavily repressed by the security forces. Tensions then escalated throughout the country, pushing some angry and frustrated Ouattara supporters to make overt declarations of war, which the leaders did not take seriously at the time. It was only when the situation exploded that the leaders started to put the pieces together. These 1995 and 2000 debacles were strictly linked to the "Ivoirité" movement. Put together, they triggered the fighting in September 2002. The three proximate causes above were the main contributing factors that triggered the civil war in Côte d'Ivoire in the first place. As for the root causes, they only permeated and created the conditions for the outbreak of the war.

\section{Measuring the Relative Weight of the Various Causes}

My dissertation serves as a test of the idea that one cannot explain the civil war, that is, demonstrate with scientific measurement which causes were primary. In other words, the civil war in Côte d'Ivoire cannot be explained; that is, revealed to have one over-riding cause, or a network of intersecting causes whose influence can be quantified. It can, however, be understood; that is, one can identify the main contributing causes, and make some judgments about which are most influential; one can distinguish between necessary conditions, contributing conditions, and efficient (or proximate) causes.

A discussion of the root and proximate causes above showed that this was indeed true. The situation in Côte d'Ivoire was extremely complex, and the causes so intertwined, that it was very difficult to give a definitive or empirical answer as to what actually started the war in that country in September 2002. The study found that all the proximate causes discussed were linked and all relevant to the case. On the other hand, 
the root causes provided a social context and created the conditions for the outbreak of the war.

Cogneau and Mesple-Somps (2003: 102-103) have put this crisis in the context of a missed opportunity. For these authors, then the Ivoirian crisis could have been avoided had the leaders played a responsible role for which they were elected. Attackers or victims, they all played a significant role in it. Therefore the failures and blames were both collective and personal, but agency played a key role. As they put it in French:

La crise que connait actuellement la Côte d'Ivoire est d'abord une crise politique, au sens où elle aurait pu être attenuée sinon evitée par l'exercice de la responsabilité politique dans les différents camps en présence...Cependant, en perdant tout contrôle, la compétition politique a exploité et élargi les failles d'un système économique et social particuliérement fragilisé....Sur la période 1999-2002, les arrivées à la présidence du Général Guéï et de Laurent Gbagbo n'ont pas donné de signes d'une modification substantielle de comportement sur les sujets les plus critiques...En tant qu'opposant, Ouattara n'a pas manifesté une forte éthique de responsabilité face au risque d'explosion nationale..Depuis 1993, les principaux dirigeants politiques ont compté sur des manipulations politiciennes et ethnicistes pour se maintenir au pourvoir en dépit d'une légitimite entamée. Les frustrations sociales se sont alors cristalisées dans les reflexes ethniques ou xénophobes.

GRIP (2003: 40) begins with the same internal actors, but then also implicated several external actors such as France, the European Union, and International Financial Institutions (the IMF/World Bank), authors of the SAPs, as being providing a context for war through their actions. As this institute writes:

The crisis in Côte d'Ivoire is first and foremost a series of deep failures by the Ivoirian political class consumed by increasing power and material wealth, the political class was never able to resolve the problems faced by the society without using clientelism.-The inter-personal problems among elites, their individual interests, infighting within parties who had been sharing power, were put above the problems faced by the entire country. Gbagbo, Ouattara, Bédié, and Guéi, all bared a responsibility in the current crisis...They all participated (off and on) to some important political alliances, which they ruined themselves later on...It is also the failure of France and the EU. The first, France, too implicated on the ground to preserve its enormous economic interests and strategic alliances, often backed the people who are responsible for the deteriorating 
situation. France waited until the situation reached a state of no return to intervene diplomatically and impose its influence. The second, EU, very respectful of France's role and influence in the region, contented itself with the indications it received by applying in Côte d'Ivoire a politics of aid and development, often without any serious critique. Finally, the International Financial Institutions whose adjustment programs contributed to the degradation of the socio-economic conditions of Côte d'Ivoire. The unequal distribution of the resources of the country, the social tensions deriving from the huge impoverishment of the people also created slowly and unavoidably the fertile ground for all the violence.

The war in Côte d'Ivoire is a political war that started with the struggle for power by the main contenders after Houphouët-Boigny died in December 1993. Their initial contest was one for power through manipulated elections, but their actions created problems that spread beyond electoral issues. Many other post-Cold War African countries faced similar problems beginning around the same time as Houphouët-Boigny's death. Thus, we might gain some further insight into the Ivorian case by examining some of these parallel cases. What, then, does the comparative evidence from other wars that began under similar circumstances (for example, Congo Brazzaville, Central African Republic, Sierra Leone, and Liberia) have to tell us? Similarly, what can we learn from the other francophone African states (for instance, Cameroon, Burkina Faso, and Gabon) that avoided both real political reforms, but also civil war?

\section{E. Ivoirian Civil War in Comparative Perspective}

I discuss the comparative evidence from the wars in Congo-Brazzaville (19971999), Sierra Leone and Liberia during the 1990s. In this section, I discuss three nonreforming francophone African states (Burkina-Faso, Gabon, and Cameroon), and one political reforming state (Senegal) to make its case. 


\section{Congo-Brazzaville}

In October 1997, the troops loyal to former president Denis Sassou Nguesso (1979-1992) seized the capital Brazzaville, and overthrew the democratically-elected president Pascal Lissouba. When he came to power, Lissouba gave a concession to the U.S. oil company Occidental Petroleum (OXY), which paid him important arrears of government employees. Expectedly, this threatened the interests of the French oil company, Elf-Aquitaine. Sassou also benefited from the backing of Angola, as the UNITA fighters and Cabinda Nationalist Guerrillas were believed to operate in parts of Congo, where they attack the Angolan government. As for Lissouba, he had the support of President Laurent Kabila of the Democratic Republic of Congo (DRC).

The war of 1997 started in June when President Lissouba sent a detachment of forces to arrest ex-President Sassou ahead of the elections that were scheduled for July. Sassou was Lissouba's chief rival in the elections that were forthcoming, and he threatened to return to power by electoral means. The war lasted from June to October 1997, after a fierce battle between the supporters of Lissouba and Sassou, who finally assumed power after Lissouba fled the country in defeat. In January 1998, the Sassou regime held a national forum for reconciliation to ease the tensions and formed a transitional government. Nonetheless, fighting resumed in December 1998 when the former rebel forces loyal to Lissouba took up arms again. After Sassou's forces gained the upper hand, a couple agreements were signed between the two groups in November and December 1999. The war in Congo-Brazzaville war was a political one, as in Côte d'Ivoire, in the sense that it was triggered by the struggle for power in a context of political reform. It was a war where an elected president had been ousted (like Bédié). It 
was also a war between ethno-regional groups (like the Forces Nouvelles and Gbagbo's supporters). The differences are that in Congo-Brazzaville, oil was considered a crucial factor in the war, and French backing of Sassou-Nguesso against Lissouba was evident. Finally, there was a clear evidence of foreign involvement on both sides, which has yet to be proven in the Ivoirian case. As in Côte d'Ivoire, however, the structural pressures for war cannot be said to have caused the war. Rather, they only created a political context in which the leading political figures were encouraged to behave irresponsibly (Clark 2008 and Knight 2007).

\section{Sierra Leone}

It is widely accepted that the civil war in Sierra Leone was in part fueled by the civil war in neighboring Liberia. Former Liberian President Charles Taylor, who had led a faction in Liberia's civil war, reportedly sponsored the RUF as a means to destabilize Sierra Leone. The RUF fighters led by Foday Sankoh operated from neighboring Liberia. There were also members of Liberian NPFL, as well as Burkinabès. The RUF and some members of the Sierra Leone army controlled the diamond-rich areas in the south and east. In this case, natural resource was a big contributing factor in the conflict, though the struggle for power seemed to be the primary cause of the fighting. A power-sharing peace agreement signed in Lomé awarded Sankoh the post of chairman of the Commission for Strategic Mineral Resources and Development (see Campbell 2004, Gberie 2005, Richards 1996). The Sierra Leone case is a clear evidence of wars of control of the resources, and power struggle. It also demonstrates the key role of sub-regional alliances, as states like Liberia, Burkina Faso, Libya, and Nigeria got involved. 


\section{Liberia}

The civil war in Liberia started in 1989 after a failed coup attempt against

President Samuel Doe by Gio and Mano elements. Doe's internal supporters included the Krahn and Mandigo ethnic groups. On December 24, 1989, a few Libyan-trained rebels led by Charles Taylor invaded Liberia from within Côte d'Ivoire borders. With explicit support from neighboring African nations and a large section of Liberia's opposition, Taylor's National Patriotic Front of Liberia (NPFL) took over the capital.

It was in this context that ECOMOG troops (the military branch of ECOWAS), predominantly from Nigeria and Ghana, entered Monrovia and joined the Doe camp. Many non-Krahn or anti-Doe people were killed, as a result. The political context of the war was the attempt by Americo-Liberians to re-establish themselve as the dominant political force in Liberia. In this case, tribal affiliations played a key role in the split between the Krahn, Gio, and Mano people. Burkina Faso's president Blaise Compaoré provided foreign mercenaries and training bases for Taylor. Military supplies and manpower from Libya and Burkina Faso were also transported by road through the Côte d'Ivoire to Liberia. The revenues generated for the war came from diamonds, timber, rubber, gold, and iron ore. The war spilled over into Sierra Leone in 1991, when Foday Sankoh led a mixed group of Liberians and Sierra Leoneans into Kailahun in eastern Sierra Leone. Finally, a cease-fire was signed in 1996 between the warring factions, surprisingly, Taylor won the 1997 presidential elections (see Huband 1998).

The war in Liberia was also a complex one in the sense that it was a mixture of power struggle, control for the country's resources, and ancient hatred between the Americo-Liberians and local indigenous ethnic groups, as well as sub-regional sub- 
alliances. As in the other cases, the war in Liberia appears to have had multiple and overlapping "causes." None can be easily identifiable as "the" key cause. Rather, a number of different contexts must be recognized to understand how the war came about.

\section{F. Non-Wars Under Political Reform}

Despite the wave of democratization and enthusiasm that swept the African continent in the early 1990s, not all countries were forced to make significant changes to their political system. This was the case in Burkina Faso, Gabon, and Cameroon, for example. While the first country had experienced a military coup, the latter have been ruled for decades by authoritarian regimes that did not faced military intervention. In each case, the formerly de jure one-party states act now as de facto one-party states, with the same ruling parties still in charge.

Indeed, Paul Biya, Omar Bongo, and Blaise Compaoré all have had a tight grip over their respective political system. In Gabon, the former President's son now carries on his father's legacy, following Bongo's death in 2009. Except for Cameroon, the other two had been involved in others' wars, either as facilitators or accomplices. Gabon for instance, was implicated in the wars of Congo-Brazzaville for two reasons: its Elf connection, and presumably because of the Sassou-Bongo families' personal relations. As for Compaoré, he has been involved in many wars in the sub-region by supplying arms and soldiers, or training facilities, and probably profiting from this arms trafficking. Only in Côte d'Ivoire did he play a constructive role as a peace broker. Though, he was accused by Ivoirian authorities of allowing the use of his country as a training ground before the September 2002 attack. This study suggests that, in general, despite the 
pressure for political change, these three leaders have shown the kind of political skills necessary to avoid civil war, as Houphouët-Boigny once did in Côte d'Ivoire.

As for Senegal, the only reforming state, it has been able to successfully manage the peaceful transition since President Abdou Diouf left power. Unlike Côte d'Ivoire, the political process has not been manipulated for personal gain. Abdoulaye Wade has displayed much more deft and statesmanlike behavior than did Houphouët's Ivorian successors. Today, this country is among the few countries cited as good students of democracy in Africa, alongside South Africa, Botswana, Ghana, and Zambia. Although the situation with Casamance remains unresolved, this has not threatened the essential stability of the Senegalese state.

This study has made significant a contribution to various areas of inquiry. First, my dissertation has sought to contribute to the debate on the causes of civil wars in general, and the causes of the Ivoirian civil war in particular. A closely related issue is how divided polities like Côte d'Ivoire can return to the path of peaceful political development. Second, the comparative studies I used have shown that collectively all these cases faced structural pressures that might have led to violent conflicts. These structural pressures emanated from all of the same environments that conditioned the Ivorian case: the global, the regional, and the internal. In some of the cases, the leaders behaved selfishly and irresponsibility, leading their countries into the same kinds of wars that Côte d'Ivoire has faced. In others, savy rulers were able to manipulate difficult circumstances to their advantage, and remain in power without significant political reforms. Among the cases I compared here, only in Senegal did President Diouf allow reforms to proceed in a way that did not upset the country's fragile social peace and civil 
institutions. In all cases, the (unpredictable) agency of the key political actors had a significant bearing on the political trajectory that their countries followed.

Third, my dissertation has also contributed to three other important areas: (a) The study was an empricial case that other researchers could use as a reference for future wars. (b) The study also made a contribution to the theoretical literature by proposing generic typologies of the causes of civil wars in general, and in the African context. Specifically, my dissertation has also shown that civil war in Côte d'Ivoire has evolved as a type-two (war agasint the state) to a type-four war (control over the local resources). (c) It has contributed to the policy area, especially conflict prevention. The policy message was that focus has to be on prevention, and thus on the proximate causes.

Despite all the difficulties much has being done to try to put Côte d'Ivoire back on its feet. As Daddieh (2001: 18-19) has well stated: Although the political crisis is far from over, the situation can be considered to have been defused. The re-instatement of Ouattara's nationality coupled with the conciliatory response of President Gbagbo, have pulled the country back from the brink of full-scale ethno-religious conflict.

New elections are set for early 2010 in which fourteen candidates will compete. This juncture marks another opportunity for Côte d'Ivoire's leading political figures to display their statemenship, and perhaps to put the country again on the road to peaceful development. 


\section{LIST OF REFERENCES}

Abbott, G. Debt Relief and Sustainable Development in Sub-Saharan Africa, Aldershot: Edward Elgar, 1993

Abdulai, S. Y.. Africa's External Debt: an Obstacle to Economic Recovery, Vienna: The OPEC Fund for International Development (Pamphlet Series 1990: No.7)

Abdullah, I. and P. Muana (1988). "The Revolutionary United Front of Sierra Leone: A Revolt of the Lumpen Proletariat," in Christopher Clapham, African Guerrillas, London: James Currey, pp. 172-193

Abubakar, Ahmad. Africa and the Challenge of Development: Acquiescence and Dependency versus Freedom and Development, New York: Praeger, 1989

Adejumobi, Said (February 2001). "Citizenship, Rights, and the Problem of Conflicts, and Civil Wars in Africa," Human Right Quarterly, 23 (1): 148-170

Adepoju, Aderanti (1983). "Patterns of Migration by Sex," in Christine Oppong, Female and Male in West Africa, Boston: Allen and Unwin, pp. 54-75

Affi, Nguessan. "Notre Problème, C'est la Droite en France,” Le Temps, 17 July 2003

Afrique Contemporaine. "Dossier Côte d'Ivoire," No.183, Janvier-Mars 2000

Afrique-Asie. “Tango Tragique Franco-Ivoirien,” No.183, Décembre 2004

Agence Française de Dévéloppement (AFD). Perspectives Economiques et Financière des Pays de la Zone Franc, Paris: Projection Jumbo 2002-2003, Septembre 2002

Aggrey, Albert. Guide des Institutions Politiques et Administratives (Guides Pratiques du Droit Ivoirien Series), Abidjan: Juris-Conseils, 1983

Ajayi, J.F. Ade and Michael Crowder (eds.). History of West Africa, 2, New York: Columbia University Press, 1974

Ake, Claude. A Political Economy of Africa, London: Longman Publishers, 1981

Akindès, Francis (1995). "Dévaluation et Alimentation à Abidjan (Côte d'Ivoire)," Les Cahiers de la Recherche En Dévéloppement, No.40, pp. 24-42

Akindès, Francis. Les Mirages de la Démocratie en Afrique Sub-Saharien Francophone, Dakar et Paris: CODESRIA-Karthala, 1996 
Akindès, Francis (1999). "Food Strategies of Urban Households in Côte d'Ivoire following the 1994 CFA Franc Devaluation," Food Policy, 24 (5): 479-494

Akindès, Francis (2001). Dynamique de la Politique Sociale en Côte d'Ivoire, Geneva: UN Research Institute for Social Development, p. 53

Akindès, Francis (2000). "Inégalités Sociales et Régulation Politique en Côte d'Ivoire," Politique Africaine. No.78, pp. 126-141

Akindès, Francis (2003). "Côte d'Ivoire: Socio-Political Crises, "Ivoirité," and the Course of History," African Sociological Review, 7, 2

Akindès, Francis. The Roots of the Military-Political Crises in Côte d'Ivoire, Urppasala: Nordiska Afrikainstitutet, 2004

Alschuler, Lawrence R.. Le Dévéloppement du Capitalisme en Côte d'Ivoire. Paris: Minuit, 1967

Amin, Samir. "Capitalism and Development in the Ivory Coast," in I.L. Markovitz African Politics and Society, New York: Free Press, 1970

Amondji, Marcel. Félix Houphouët et la Côte d'Ivoire, Paris: Karthala, 1984

Amondji, Marcel. Côte D'Ivoire: Le PDCI et la Vie Politique de 1944 à 1985, Paris: L'Harmattan, 1986

Azam, Jean-Paul (February 2002). "Looting and Conflict Between Ethno-Regional Groups: Lessons for States Formation in Africa," Journal of Conflict Resolution, 46 (1): 131-153.

Bach, Daniel (1982). 'L'Insertion Dans Les Rapports Internationaux,' in Y.-A. Fauré and J.-F. Médard, Etat et Bourgeoisie en Côte D'Ivoire, Paris: Karthala, pp. 89-121

Bailly, Diégou La Restauration du Multipartisme En Côte d'Ivoire ou la Double Mort de Houphouêt-Boigny, Paris: L’Harmattan, 1995

Bakary, Tessilimi (1984) "Elite Transformation and Political Succession" in I. William Zartman and Christopher Delgado. The Political Economy of Ivory Coast, New York: Praeger, pp. 21-56

Balesi, Charles John. From Adversaries to Comrades-in-Arms: West Africans and the French Military, 1885-1918, Waltham (MA): Crossroads Press, 1979

Ballentine, Karen, and Jake Sherman. The Political Economy of Armed Conflict: Beyond Greed and Grievance, Boulder (CO): Lynne Rienner, 2003 
Banégas, Richard and Bruno Losh (October 2002). "La Côte d'Ivoire au Bord de L’implosion." Politique Africaine, No.87, pp. 139-161

Banégas, Richard and Ruth Marshall-Fratani (2000). "Côte d'Ivoire, Un Conflit Régional? Politique Africaine, No.78, pp. 5-11

Barkan, Steven E. and Lynn L. Snowden. Collective Violence, Boston (MA) Allyn and Bacon, 2001

Barrows, Walter (1976). "Ethnic Diversity and Political Instability in Black Africa," Comparative Political Studies 9 (2): 139-170.

Bassetts, J. Thomas (Eté 2003). "Nord Musulman et Sud Chrétien: Les Moules Médiatiques de la Crise Ivoirienne.” Afrique Contemporaine, pp. 13-27

Baulin, Jacques. La Politique Africaine d'Houphouët-Boigny, Paris: Eurafor-Press, 1980

Baulin, Jacques. La Politique Intérieure d'Houphouët-Boigny, Paris: Eurafor Press, 1982

Bayart, Jean-François. “L’Ivoirité Vient de Loin,” L'Express, 15 Novembre 2004

Bédié, Konan Henri. Les Chemin de Ma Vie, Paris: Plon, 1999

Bénot, Yves. Idéologies des Indépendances Africaines, Paris: Maspéro, 1969

Berdal, M. et David Malone (eds.). Greed and Grievance: Economic Agendas of Civil War, Boulder (CO): Lynne Rienner, 2000

Bienen, Henry. Armies and Parties in Africa, New York: Africana Publishing, 1979

Bienen, Henry. Armed Forces, Conflict, and Change in Africa, Boulder: Westview Press, 1989

Blackaby, F (March 1987) “The Causes of War, Science and Peace," Bulletin of Peace Proposals, Vol.18, Issue 1, pp. 13-18

Blackburn, Brigitte (April 1987) 'L'Afrique Poignardée Par L'Occident: Le Cas de la Côte d'Ivoire,' Africa International, Dakar (Senegal), No.194, pp. 13-16

Blainey, Geoffroy. The Causes of Wars, London: McMillan, 1988

Bøas, Morten (October 2001). "Liberia and Sierra Leone: Dead Ringers? The Logic of Neopatrimonialism Rule," Third World Quarterly, 22 (5): 697-723 
Bøas, Morten and Kevin C. Dunn. African Guerrillas: Raging Against the Machine, Boulder (CO): Lynn Rienner, 2007

Bollerup, Soren R. and Christian D. Christensen. Nationalism in Eastern Europe: Causes and Consequences of the National Revivals and Conflicts in Late Twentieth Century Eastern Europe, New York: St. Martin's Press, 1997

Boone, Catherine (March 1993) "Commerce in Côte d'Ivoire: Ivoirisation Without Ivoirian Traders," The Journal of Modern African Studies, 3 (1): 67-92

Bossard, Laurent (Eté 2003). "Peuplement et Migration en Afrique de L'Ouest: Une Crise Régionale en Côte d'Ivoire," Afrique Contemporaine, pp. 151-165.

Bourgoin, Henri and Philippe Guillaume. La Côte d'Ivoire: Economie et Société, Paris (France): Stock, 1979

Bourke, Gerald (November-December 1987). "A Tarnished Miracle," Africa Report, 32 (6): $62-64$

Bratton, Michael and Nicholas van de Walle. "Popular Protest and Political Reform in Africa," Comparative Politics, 24, July 1992

Bratton, Michael and Nicholas van de Walle (July 1994). Neopatrimonial Regimes and Political Transitions in Africa," World Politics, 46 (4): 453-489

Brayton, Abbott A. (Winter 1979) "Stability and Modernization: The Ivory Coast Model," World Affairs, 5 (141): 235-49

Brown, Michael E.. The International Dimensions of Internal Conflict, Cambridge: MA: MIT Press, 1996

Buhaug, Halvard and Scott Gates (2002). "Geography of Civil War," Journal of Peace Research, 39 (4): 417-433

Bundy, Willam P. The World Economic Crisis, New York: Norton \& Company, 1975

Cabrillac, Bruno (1er Trimestre 2000). "Les Aspects Economiques et Financiers de la Crise Ivoirienne." Afrique Contemporaine, No.193, pp. 38-44

Campbell, Bonnie (1987) "The State and Capitalist Development in the Ivory Coast," in Paul M. Lubeck (ed.), The African Bourgeoisie: Capitalist Development in Nigeria, Kenya, and the Ivory Coast, Boulder (CO): Lynne Rienner, pp. 281-303

Campbell, Greg. Blood Diamonds : Tracing the Deadly Path of the World's More Precious Stones. New York : Basic Books, 2004 
Campbell, Bonnie (2000). 'Reinvention du Politique en Côte d'Ivoire,' Politique Africaine, No.78

Campbell, Bonnie (1978). “The Ivory Coast," in John Dunn (ed.), West African States:

Failure and Promise, Cambridge: Cambridge University Press, pp. 66-116

Cashman, Gerg. What Causes War? An Introduction of International Conflict, New York: Lexington Books, 1993

Cathelin, Melanie. "Dynamiques Regionales d'Insécurité en Afrique de L'Ouest," Institut Québécois des Hautes Etudes Internationales, No.7, Janvier 2004

Chabal, Patrick. Political Domination in Africa (African Studies Series), Cambridge: Cambridge University Press, 1986

Chafer, Tony (2001). "French African Policy in Historical Perspective," Journal of Contemporary African Studies, 19 (2): 165-181

Chaléard, Jean-Louis (1er Trimestre 2000). 'Les Derniers Carrés de Chocolat: La Fin d'Un Système Economico-Politique en Côte d'Ivoire?,' Afrique Contemporaine, No.193, pp. 45-55

Chandra, Kanchan (2005). "Ethnic Parties and Democratic Stability," Perspectives on Politics, 3 (2): 235-252.

Chazan, Naomi et al. Politics and Society in Contemporary Africa (3ed), Boulder: Lynn Rienner, 1999

Chazan, Naomi (1992). “Africa’s Democratic Challenge,” World Policy Journal 9 (2): 279-308

Chesterman, Simon. Civilians in War, Boulder (CO) and London: Lynne Rienner, 2001

Chevassu, Jean-Marie ( $2^{\mathrm{e}}$ Semestre 2001). 'Une Crise Sous la Crise Ou L'impossible Compétitivité: Quarante Ans d'Industrialisation en Côte d'Ivoire,'Afrique Contemporaine, No.198, pp. 10-28

Cheveau, Jean-Pierre et Koffi Samuel Bobo (Mars 2003). "La Situation Dans L'Arène Villageoise: Un Example Dans le Centre-Ouest Ivoirien." Politique Africaine, No.89, pp. $2-25$

Chipman, John. French Military Policy and African Security, London: International Institute for Strategic Studies, 1975

CIA Factbook - Côte d'Ivoire, 1990-2002 
Clapham, Chistopher. African Guerrillas, Oxford: James Currey, 2000

Clapham, Christopher (July 2000). "Civil Wars in Africa: Roots and Resolution," The Journal of Modern African Studies, 38 (2): 326-328

Clapham, Cristopher (March 1998). 'Africa and Europe: The Changing Economic Relationship; La France dans L'Afrique de L'après-Guerre Froide: Interventions et Justifications,' The Journal of Modern African Studies, 36 (1): 169-170

Clark, F. John. The African States of the Congo War, Kampala: Fountain Publishers, 2002

Clark, F. John. The Failure of Democracy in the Republic of Congo. Boulder: Lynne Rienner, 2008

Cogneau, Denis et al. (Eté 2003). 'Côte d'Ivoire: Histoires de la Crise' Afrique Contemporaine, pp. 5-12.

Cogneau, Denis et Sandrine Mesple-Somps (Eté 2003) "Les Illusions Perdues de L’Economie Ivoirienne et la Crise Politique,"Afrique Contemporaine, pp. 87-104.

Cohen, Michael A. (June 1973) "The Myth of Expanding Center--Politics in the Ivory Coast," Journal of Modern African Studies (London), 11 (2): 227-46

Cohen, A. Michael Urban Policy and Political Conflict in Africa, Chicago: University of Chicago Press, 1974

Collier, Paul (1999) “Aid Dependency: A Critique,” Journal of African Economies, 8 (4), Special Issue, pp. 528-545.

Collier, Paul. "Doing Well Out of War: An Economic Perspective," in C.L. Gilbert, M. Tribe, and J. Weiss, Greed and Grievance: Economic Agendas in Civil Wars, Cheltenham: Edward Elgar, 2000

Collier, Paul (2001). “Implication of Ethnic Diversity,” Economic Policy 32, pp. 129-66

Collier, Paul ((December 2000). "Rebellion as A Quasi-Criminal Activity," Journal of Conflict Resolution, 44 (5): 839-853

Collier, Paul and Anke Hoeffler (February 2000). "On the Incidence of Civil War in Africa," The Journal of Conflict Resolution, 46 (1): 13-28

Collier, Paul and Nicholas Sambanis (February 2000). "Understanding Civil Wars: A New Agenda," The Journal of Conflict Resolution, 46 (1): 3-12 
Collier, Ruth Berins. Regimes in Tropical Africa, Berkeley: University of California Press, 1982

Contamin, B and Y.-A. Fauré. La Bataille des Entreprises Publiques en Côte d'Ivoire: L'Histoire d'Un Adjustement Interne, Paris: Khartala, 1990

Contamin, Bernard and Bruno Losch (2000). "Côte d' Ivoire: Entretien Avec Mamadou Koulibaly (Ministre du Budget du Gouvernement de Transition)," Politique Africaine, No.77, pp.129-142

Contamin, Bernard and Bruno Losch (Mars 2000). "Côte d'Ivoire: La Voie Etroite." Politique Africaine, No.77, pp.117-128

Contamin, et Harris Mémel-Fôté. Le Modèle Ivoirien en Question, Paris: Khartala and ORSTOM, 1997

Conte, Bernard. 'Côte d'Ivoire: La Persistance de la Crise d'Elite de L'Economie Nationale et Celle de la Sous-Région,' Centre d'Etude d'Afrique Noire (IEP de Bordeau), 6 Juin 2005

Côte d'Ivoire: Human Development Reports, 1990-2002

Côte d'Ivoire: IRIN Chronology of Key Events: December 1999-November 2002

Côte d'Ivoire: Constitution de la République de Côte D'Ivoire, Abidjan: Imprimerie Nationale, 1980

Coulibaly, A. (Hiver 2003). "Les Sept Péchés Capitaux de la Côte d'Ivoire," Géopolitique Africaine, No.9, pp.71-82

Coulibaly, Mamadou. Houphouët-Boigny 20 Ans de Sagesse, 50 Ans de Travail, Abidjan: Société Ivoirienne d'Imprimérie (S.I.I.), 1975

Coulibaly, Tiémoko (October 2000). "Entre Coups d'Etat, Elections Reportées et Mouvements Sociaux, La Classe Politique Ivoirienne Se Cherche," Le Monde Diplomatique, No. 559, pp. 22-23

Coulibaly, Tiémoko. "Cult of a Dead Dictator: Ivory Coast Democracy Differed," Le Monde Diplomatique, October 2000

Crook, C. Richard (1990). "Politics, the Cocoa Crisis, and Administration in Côte d'Ivoire," Journal of Modern African Studies, 28 (4): 649-669. 
Crook, R.C. (1997). "Winning Coalitions and Ethno-Regional Politics: Failure of the Opposition in the 1990 and 1995 Elections in Côte d'Ivoire," African Affairs, 96 (383): 215-242

Daddieh, Cyril Kofie (1984) "Ivory Coast" in Timothy M. Shaw and Olajide Aluko. The Political Economy of African Foreign Policy, New York: St. Martin's Press, pp.122-144

Darby, John and Ginty, Mac. "Conflict, Violence and Peace Processes," Houndmills, Basingstoke, Hampshire: New York: Palgrave Macmillan, 2003

David, Philippe. La Côte d'Ivoire, Paris: Karthala, 1996

Davis, Shelby Cullom. Reservoirs of Men: A History of the Black Troops of French West Africa. Westport, Connecticut: Negro Universities Press, 1970

Decalo, Samuel. Coups and Army Rule in Africa: Studies in Military Style, New Haven: Yale University Press, 1976

Decalo, Samuel. Psychoses of Power: African Personal Dictatorships, Boulder (CO): Westview Press, 1989

Decreane, Philippe (2000). "L'Eviction du President Konan Bédié: Une Revue des Faits." Afrique Contemporaine, No.193, pp.3-12

Dembélé, Ousmane (2002). 'La Construction Economique et Politique de la Catégorie “Etrangers" En Côte d'Ivoire,' in Le Pape, M. and C. Vidal (eds.), Côte D'Ivoire: L'Année Terrible 1999-2000, Paris: Karthala, pp. 123-171

Dembélé, Ousmane (2003) "Abidjan: De la Territorialisation de la Sécurite à la Fragmentation de la Société Urbaine," in F. Leimdorfer et A. Marie, pp. 155-194

Den Tuinder, Bastian A. Ivory Coast: The Challenge of Success, Baltimore: Johns Hopkins University Press, 1978

Diallo, Youssouf. "From Stability to Uncertainty: A Recent Political History of Côte d'Ivoire," Max Planck Institute for Social Anthropology (Working Paper No.74) http://www.eth.mpg.de

Diarra, S. Les Faux Complots d'Houphouêt-Boigny: Fracture Dans Le Destin d'Une Nation (1959-1970), Paris: Karthala, 1997

Diop, Boris Boubacar. "France in Francophone Africa: Ivory Coast Colonial Adventure" in Le Monde Diplomatique, April 2005 
Djelhi, Yahot Adamo. "La Crise De Liquidité Dans L'Economie Ivoirienne Des Années 1980-1990," Thèse de Doctorat, Université de Versailles Saint-Quentin-En Yvelines (France), 2002

Dosso, Moussa. Responsible Des Resources Financières En Zone Forces Nouvelles, Interview Sur Abidjan.net, 8 January 2006

Doza, Bernard. "Naissance d'Un Nationalism Ivoirien," Le Monde Diplomatique, Mars 2003

Dozon, Jean-Pierre (1997). “L'Etranger et L'Ottochtone en Côte D'Ivoire," in Bernard Contamin et Harris Mémel-Fôté. Le Model Ivoirien en Question : Crises, Adjustments, Recompositions, Paris: Karthala, pp. 229-237

Dozon, Jean-Pierre (2000). "La Côte d'Ivoire Entre Democratie, Nationalisme et Ethnonationalism.” Politique Africaine No.78, pp. 45-62

Dozon, Jean-Pierre (2000). “La Côte d'Ivoire: Au Péril de L'Ivoirité: Génèse d'Un Coup D’Etat," Afrique Contemporaine, No.193, pp. 13-23

Dunn, John. West African States: Failure and Promise, Cambridge: Cambridge University Press, 1978

Duodu, Cameron. "Who Wants to Burn Côte D'Ivoire?” New African, November 2000, p. 32

Duprey, Pierre. Histoire Des Ivoiriens: Naissance D'Une Nation, Abidjan: Imprimerie Nationale de Côte D'Ivoire, 1962

Economist Intelligence Unit. Quarterly Economic Review of Ivory Coast, Togo, Benin, Niger, Upper Volta: Annual Report, London: The Economist, 1983

Edi, Eric. "Pan West Africanism and Political Instability in West Africa: Perspectives and Reflections." The Journal of Pan-African Studies, vol.1, no3, March 2006

Ekanza, Simon-Pierre. La Côte d'Ivoire par les Textes: De L'aube de la Colonisation à Nos Jours, Abidjan: NEA, 1978

Elbadawi, Ibrahim and Nicholas Sambanis (2002)."How Much War We Will See? Explaining the Prevalence of Civil War", Journal of Conflicts Resolution, 46 (3): 307334

Fauré, Y.-A. (1982) 'Le Complexe Politico-Economique' in Y.-A. Fauré And J.-F. Médard. Etat et Bourgeoisie en Côte d'Ivoire. Paris: Karthala, pp. 21-60 
Fauré, Y.-A., and J.-F. Médard (1982). Classe Dominante Ou Classe Dirigeante?' in Y.A. Fauré and J.-F. Médard (eds.), Etat et Bourgeoisie en Côte d'Ivoire, Paris: Karthala, pp. $125-148$

Fearon, James D. \& David D. (February 2003). "Ethnicity, Insurgency, and Civil War," American Political Science Review 97 (1): 75-90

Fearon, James D. (2004). "Why Do Some Civil Wars Last Longer Than Others?" Journal of Peace Research, 41 (3): 275-301

Fieldhouse, D.K. Black Africa, 1945-1980: Economic Decolonization and Arrested Development, London: Allen and Unwin, 1986

Fraternité Matin. Deux Décénies de Turbulence, 28 Avril 2003

Frieden A. Jeffry and David A. Lake. International Political Economy: Perspectives on Global Power and Wealth (4 ${ }^{\text {th }}$ ed), Boston, New York: Bedfor/St. Martin's, 2000

Galy, Michel. 'Côte D'Ivoire: La Violence, Juste Avant La Guerre, Afrique Contemporaine, Printemps 2004

Gantzel, Akaus Jurgen. Journal of Peace Research, Vol.18, Issue 1, (January-March 1981): 39-55

Gastil, Raymond D. (1986). "Ivory Coast," in Raymond D. Gastil (ed.), Freedom in the World: Political Rights and Civil Liberties, 1985-1986. Westport, Connecticut: Greenwood Press, p. 320

Gates, Scott. (2002). "Recruitment and Allegience: The Micro-Foundations of Rebellion," Journal of Conflict Resolution 46 (1): 111-130

Gates, Scott. "Empirically Assessing the Causes of Civil War" Mimeo, International Peace Research Institute, 9 December 2001

Gaulme, Francois (4 ${ }^{\mathrm{e}}$ Semestre 2000). "Côte d'Ivoire: La Logique Des Urnes et Celles de la Violence,” Afrique Contemporaine, No.196, pp. 99-109

Gbagbo, Laurent. La Côte d'Ivoire: Économie et Société à la Veille de L'Indépendance (1940-1960), Paris: L'Harmattan, 1982

Gbagbo, Laurent. Côte d'Ivoire: Pour Une Alternative Démocratique, Paris: L'Harmattan, 1983

Geertz, Clifford. Old Societies and New States: The Quest for Modernity in Asia and Africa, New York: Collier-MacMillan, 1963 
Gérard, Claude. Les Pionniers de L'Indépendance, Paris: Editions Inter-Continents, 1974

Giddings, R. L., Jr (1968). “On Understanding War,” U.S. Naval Institute Proceedings 94 (7): $27-37$

Gilbert, Margaret. Living Together: Rationality, Sociality, and Obligation, Lanham, Maryland: Rowman and Littlefield, 1996

Gnako, C. “La Côte D’Ivoire N'est Pas Un Pays Xénophobe”, Notre Voie, du 6 Octobre 2000, No.720, p. 4

Goldsworthy, David (January 1981). "Civilian Control of the Military in Black Africa," African Affairs (London), 80 (318): 49-74

Goode, Erich. Collective Behavior, Forthworth: Saunders College Publishers, 1992

Gozo, K.M. (June 1983) Crise et Pauvreté en Côte D'Ivoire, Addis Ababa (Ethiopia):

Bureau International du Travail, Programme Des Emplois et Des Compétences

Techniques Pour L'Afrique, pp. 61-65

Gramizzi, Claudio. "La Crise Ivoirienne: De la Tentative de Coup d'Etat $\mathrm{Au}$

Gouvernement de Réconciliation Nationale," http://www.grip.org

Grindle, M. Serrill. Getting Good Government: Capacity Building in the Public Sectors of Developing Countries. Cambridge (MA): Harvard University Press, 1997

Grindle, M. Serrill and Thomas, John W. Public Choices and Policy Change: The Political Economy of Reform in Developing Countries, Baltimore: Johns Hopkins University Press, 1991

Guéhenno, Jean. La France et les Noirs, Paris: Guillamard, 1954

Guimares, Fernando Andersen. The Origins of The Angolan Civil War: Foreign Intervention and Domestic Political Conflict. New York: St. Martin's Press, 1998

Gurr, Ted Robert. Why Men Rebel? Princeton: Princeton University Press, 1970

Gurr, Ted Robert (1994). "Peoples against States: Ethnopolitical Conflict and the Changing World System," International Studies Quarterly 38, pp. 347-377

Gurr, Ted Robert Peoples versus States: Minorities at Risk in the New Century, Washington DC: United States Institute of Peace Press, 2000

Gurr, Ted Robert. Minority at Risk: A Global View of Ethnopolitical Conflicts, Whashington D.C.: United States Institute For Peace, 1993 
Gurr, Ted Robert and Barbara Harff. Ethnic Conflict in World Politics, Boulder: Westview Press, 1994

Gurr, Ted Robert and Muriel McClelland. Political Performance: A Twelve-Nation Study, Beverly Hills: Sage Publications, 1971

Gurr, Ted Robert, Barabara Harff, Monty G. Marshall, and James R. Scaritt. Handbook of Political Conflict: Theory and Research, New York: Free Press, 1980

Hameso, Seyoum. "Issues and Dillemas of Multiparty Democracy in Africa," West Africa Review, 2002

Hanning, Hugh (1967) "Ivory Coast" in Hugh Hanning (ed.), Peaceful Uses of Military Forces. New York: Praeger, pp. 133-140

Hardy, Chandra (1986). “Africa's Debt: Structural Adjustment with Stability," in Robert Berg and Jennifer Whitaker. Strategies for African Development: A Study for the Committee on African Development Strategies, Berkeley: University of California Press, pp. 453-475

Harshé, Rajen. Pervasive Entente: France and Ivory Coast in African Affairs, Atlantic Highlands (New Jersey): Humanities Press, 1984

Haynes, Jeffrey. Democracy in the Third World: Africa, Asia, Latin America, and the Middle East, Cambridge (UK): Polity Press; MA in Association With Blackwell, 2001

Hecht, Robert M. (March 1983). “The Ivory Coast Economic 'Miracle': What Benefits for Peasant Farmers?” Journal of Modern African Studies (Cambridge), No. 21, pp. 25-53

Henderson, A. Errol and J. David Singer (2000). "Civil War in the Post-Colonial World, 1946-92," Journal of Peace Research, 37 (3): 275-299

Henderson, Errol E (Summer 2000). "When States Implode: The Correlates of Africa's Civil Wars, 1950-92," Studies in Comparative International Development, 35 (2): 28-47

Hentz, James J. and Morten Bøas. New and Critical Security and Regionalism: Beyond the Nation State. Aldershot; England, Burlington, and Vermont: Ashgate, 2003

HIPC Unit. Financial Impact of the HIPC Initiative: First 22 Countries Cases, Washington D.C.: World Bank, 2001

Hodonou, Valentin. "Paris-Abidjan à Bout de Souffle." Afrique-Asie, No.171, Décembre 2003

Houphouët-Boigny, Félix. Mes Premiers Combats, Abidjan: NEI, 1984 
Howard, Michael (March 1982) "The Causes of War,” Encounter, Vol. LVIII, Issue 3, pp. $22-30$

Howard, Michael Elliot. The Causes of Wars and the Other Essays, Cambridge (MA): Harvard University Press, 1983 and 1984

Huband, Mark. The Liberian Civil War, London/New York: Frank Cass \& Co., 1998

Hugon, Phillipe (Eté 2003) "La Côte d'Ivoire: Plusieurs Lectures Pour Une Crise Annoncée," Afrique Contemporaine, pp. 105-127

Human Rights Watch. "The New Racism: The Political Exploitation of Ethnicity in Côte d'Ivoire." Vol.13, No.6 (A), August 2001

Huntington, Samuel. The Third Wave of Democratization in the Late Twentieth Century, Norman: University of Oklahoma Press, 1991

Ihonvbere, O. Julius (March 1994) “The Debt Crisis in Africa," The Journal of Modern African Studies, 32(1): 159-161

Jackson, Robert H. and Carl G. Rosberg. Personal Rule in Black Africa: Prince, Autocrat, Prophet, Tyrant, Berkeley: University of California Press, 1982

James, Patrick (October 1995). "Structural Realism and the Causes of War," International Studies Quarterly, Supplement 2 (39): 181-208

Janin, Pierre. "Cult of A Dead Dictator: Alienation in Abidjan," Le Monde. October 2000

Jarret, M.-F. et F.-R. Mathieu. La Côte D'Ivoire: De la Destabilisation à la Réfondation, Paris: L'Harmattan, 2002

Jean F. et J.-Ruffin (dir). L'Economie Des Guerres Civiles, Paris: Hachette Collection, 1996

Johnson, Douglas Hamilton. The Root Causes of Sudan's Civil Wars. Bloomington: Indiana University Press, and Kampala: Fountain Publishers, 2003

Jumbo, Equipe ((Eté 2003) "La Crise Ivoirienne et Son Impact Régional: Régard Sur L'Actualité et Scénarios Pour L'Avenir,' Afrique Contemporaine, pp.129-150

Jung, Dietrich. Shadow Globalization, Ethnic Conflicts, and New Wars: A Political Economy of Intra-State War, New York (NY): Routledge, 2003 
Kaarsholm, Preben. Violence Political Culture \& Development in Africa: Congo, Rwanda, Darfur, Liberia, Sierra Leone, Ethiopia, Matabeleland, Kwazulu-Natal, Oxford: James Currey, and Athen: Ohio University Press, 2006

Kaldor, M. New and Old Wars Organized Violence in a Global Era, Oxford: Polity Press, 1999

Kanet, Roger E. Resolving Regional Conflicts, Urbana: University of Illinois Press, 1998

Kieffer, Guy-André. “Armée Ivoirienne: Le Refus du Déclassement,"Politique Africaine, No.78, Juin 2000

Kilson, Martin. Political Change in a West African State, Cambridge: Harvard University Press, 1966

King, Charles. Ending Civil Wars, Oxford (England); New York (NY): Oxford University Press for the International Institute for Strategic Studies, 1997

King, Erika G. Crowd Theory as a Psychology of the Leader and the Led, Lewiston: E. Mellen Press, 1990

Klare, Michael T. Resources Wars, New York: Metropolitan, 2007

Knight, Cassie. Brazzaville Charms: Magic in the Republic of Congo. United States: Frances Lincoln Limited, 2007

Koffi, N. (1996) “The Concept of L'Ivoirité” in L'Ivoirité Ou L'esprit Du Nouveau Contrat Social Du Président Henri Konan Bédié, Abidjan: PUCI, pp. 25-32.

Konaté, A. Siendou. "The Politics of Identity and Violence in Côte d'Ivoire." West African Review, Issue 5, 2004

Konaté, Yacouba (2003). "Les Enfants De La Balle: De La Fesci Aux Mouvements de Patriotes,"Politique Africaine, No. 89, pp. 49-78

Koné, A. Houphouêt-Boigny et la Crise Ivoirienne, Paris: Karthala, 2003

Kouadio, K. Bertin. "Côte d'Ivoire: Society and Cultures," in John Middleton (ed.), New African Encyclopedia, By Scribner Son’s, 2007

Kouadio, K. Bertin. "Democratic Experiment in Africa: How did Côte d'Ivoire Become a Victim of the Civil War?", Paper presented at the $10^{\text {th }}$ Anniversary of the AFRICANDO International Conference, Organized by the Foundation for Democracy in Africa, September 19-22, 2007 in Miami, Florida 
Kouadio, K. Bertin. "The Use of Indigenous Ivoirian Leaders in the French Colonial Administration: The Case of the Baule of Yamoussoukro," Paper Supervised by Professor Charles Stewart at the University of Illinois at Urbana-Champaign, 1998

Kouadio, K. Bertin and Alma Gottlieb. "Côte d'Ivoire: Peoples and Cultures" in John Middleton (ed.), Encyclopedia of Sub-Saharan Africa, Simon and Schuster, 1997

Koulibaly, Mamadou (1999). 'Enjeux Economiques, Conflicts Africains et Relations Internationales,' Africa Development, Vol. XXIV, (3 \& 4), 19-45

Koulibaly, Mamadou (2000). "Côte d'Ivoire: Entretien Avec Mamadou Koulibaly," Politique Africaine, No. 77, pp. 129-142

Koulibaly, Mamadou et al. La Guerre de la France Contre la Côte d'Ivoire, La Réfondation, Abidjan : Imprimerie Nationale de Côte d'Ivoire, Mai 2003

Koumoué, Koffi Moise. Politique Economique et Adjustement Structurel en Côte d'Ivoire, Paris: L'Harmattan, 1994

L'Intelligent d'Abidjan "Les Preuves de L’imposture”, July 2004

Lamb, David (Autaum 1988) “A Different Path,” The Wilson Quarterly, 12 (4): 114-131

Lancaster, C. Aid to Africa: So Much to Do, So Little Done, Chicago: University of Chicago Press, 1999

Laremont, Ricardo Rene. The Causes of War and the Consequences of Peacekeeping, Portsmouth (NH): Heinemann, 2001a

Le Billon, Philippe (2001a). "Angola's Political Economy of War: The Role of Oil and Diamonds 1975-2000," African Affairs 100 (398): 55-80

Le Billon, Philippe. Fuelling War: Natural Resources and Armed Conflicts, Oxford: Oxford University Press for the International Institute of Strategic Studies, 2001b

Le Billon, Phillippe (2001). "The Political Ecology of War: Natural Resources and Armed Conflicts," Political Geography 20 (5): 561-584

Le Courier D’Abidjan. “Blé Goudé: L’armée Française Avait Une Mission de Coup d'Etat, 15 Novembre 2004

Le Monde (18 November 2004). 'La Crise En Côte d'Ivoire'

Le Monde Diplomatique (April 1999). “One Step Forward, Two Steps Back: Fifteen Conflicts." 
Le Nouveau Réveil (30 April 2003). 'Houphouêt, Yacé, Bédié, Ado, et Gbagbo: La Part de Responsabilité de Chacun Dans Cette Crise Vieille de 15 ans.

Le Pape, Marc (Eté 2003) "Les Politiques d'Afrontement en Côte D'Ivoire 1999-2003," Afrique Contemporaine, pp. 29-39

Le Pape, Marc Et Claudine Vidal. L'année Terrible, 1999-2000, Paris: Karthala, 2002

Lewis, Peter. Africa: Dilemmas of Development and Change, UK: Westview Press, 1998

Liebenow, J. Gus. African Politics, Bloomington: Indiana University Press, 1986

Lindsay, Moir. The Law of Internal Armed Conflict, Cambridge (UK): Cambridge University Press, 2002

Liphart, Arend. "The Wave of Power-Sharing Democracy," in Andrew Reynolds. The Architecture of Democracy, Oxford: Oxford University Press, 2002

Lisette, Gabriel. Le Combat du RDA, Paris: Présence Africaine, 1978

Losch, Bruno (2000). "Coût de Cacao en Côte d' Ivoire : Economie Politique d 'Une Crise Structurelle," Critique Internationale, No. 9, pp. 6-14

Losch, Bruno (2000). "L'Impasse Ivoirienne," Observatoire Permanent de la Coopération Française (OPCF): Rapport Annuel 2000, Paris: Karthala, pp. 201-212

Losch, Bruno (2000). "La Côte d' Ivoire en Quête D'un Nouveau Projet National," Politique Africaine, Numéro Spécial Côte d'Ivoire -No.78 : 5-25

Losch, Bruno (2000). "La Côte d'Ivoire Au Bord de L'implosion,” Politique Africaine, No.87, pp. 139-162

Losch, Bruno (April 2002). "Global Restructuring and Liberalization: Côte d'Ivoire, and the End of the International Cocoa Market?," Journal of Agrarian Change, 2 (2): 206227

Loucou, Jean-Noêl (1980) "La Deuxième Guerre Mondiale et Ses Effets en Côte d 'Ivoire," Annales de l'Université d'Abidjan, Série I, 8, pp.183-207

Loucou, Jean-Noêl. Histoire de La Côte d'Ivoire: La Formation des Peuples, Abidjan: CEDA, 1984

Marenin, Otwin (July 1982). "Policing African States: Toward A Critique," Comparative Politics, 14 (4): 379-396 
Marret, J.-L. La Fabrication de la Paix: Nouveaux Conflicts, Nouveaux Acteurs, Nouvelles Méthodes, Paris: Ellipses, 2001

Martin, Guy (1989). “Uranium: A Case Study in Franco-African Relations,” The Journal of Modern African Studies, 27 (4): 625-640

Martin, Guy (March 1995). Continuity and Change in Franco-African Relations, The Journal of Modern African Studies, 33 (1): 1-20

Mbembe, Achille. Migration of Peoples, Disintegration of States: Africa's Frontiers in Flux, Le Monde Diplomatique, November 1999

McGowan, J. Patrick (2003). “African Military Coup d'Etat, 1956-2001: Frequency, Trends, and Distribution," Journal of Modern African Studies, 41 (3): 339-370

McPhail, Clark. The Myth of the Madding Crowd, New York: A.De Gruyter, 1991

Me-Rill, A.B (July 1982). “The Causes of War” Military Review, 62 (Issue 7): 44-52

Midlarsky, Manus I. Internationalization of Communal Strife, London; New York: Routledge, 1992

Mkandawire, T. and A. Olukoshi. Between Liberalization and Repression: The Politics of Structural Adjustment in Africa, Dakar (Senegal): CODESRIA, 1995

Mkandawire, T. and Soludo, C. “Our Continent, Our Future," Trenton: Africa World Press Inc., 1998

Moncrieff, Richard French Development Aid and the Reforms of 1998-2002. University of Southampton, School of Humanities, PhD Thesis 2004, 274p.

Monga, Célestin (September 1999) "Civil Society and Démocratization in Francophone Africa," The Journal of Modern African Studies, 33 (3): 359-379

Moose, George (1985). "French Military Policy in Africa," in William J. Foltz and Henry S. Bienen (eds.), Arms and the Africans. New Haven: Yale University Press, pp. 59-79

Morgenthau, R. Schachter. Political Parties in French-Speaking West Africa, Oxford: Clarendon Press, 1964

Mortimer, Edward. France and the Africans 1944-60: A Political History. New York: Walker And Company, 1969

Mousseau, Demet Yalcin (September 2001). "Democracy With Ethnic Divisions: A Source of Conflict? Journal of Peace Research, 38 (5): 547-567 
Mshomba, Richard E. Africa in the Global Economy, Boulder (CO) and London (UK): Lynn Rienner, 2000

Mundt, Robert J. Historical Dictionary of the Ivory Coast (African Historical Dictionaries, No. 41, Metuchen (NJ): Scarecrow Press, 1987

Mundt, Robert J. "Internal Criticism of the Ivoirian Political Regime," Paper presented at the African Studies Association Annual Meeting in Denver, Colorado, 20 November 1987

Murdock, C. James and Todd Sanders (February 2002). "Economic Growth, Civil Wars, and Spillovers", the Journal of Conflict Resolution, 46 (1): 91-110

Nazi, Boni. Crépuscule des Temps Anciens, Paris: Présence Africaine, 1962

Ndiaye, Boubacar "Not A Miracle After All...Côte d'Ivoire's Downfall: Flawed Civil Military Relations and Missed Opportunities." Non-published paper.

Nenig, Jeffrey R. Neighborhood Mobilization: Redeployment, and Response, New Brunswick, N. J.: Rutgers University Press, 1982

Neuberger, Benjamin. National Self-Determination in Postcolonial Africa, Boulder (CO): Lynne Rienner, 1986

Neuman, Edward and S. Albrecht. Recovering From Civil Conflict: Reconciliation, Peace, and Development, London: Portland (OR): F. Cass, 2002

Newbury, Catherine (April 2002) "State at War: Confronting Conflict in Africa," African Studies Review, 45 (1): 1-20

Niangoran-Bouah, G. (1996). "Les Fondements Socio-Culturels de L'Ivoirité," in L'Ivoirité Ou L'esprit du Nouveau Contrat Social du President Henri Konan Bédié. Abidjan: PUCI, pp. 45-52

Nicholson, Michael (July 1999). "Lewis Fry Richardson and the Study of the Causes of War," British Journal of Political Science, 29, Issue, p. 541

Notre Voie (15 December 2004) "Laurent Gbagbo: Nous Avons Pris le Combat Ou le PDCI L'A Laissé."

Nyong'oro, Peter Anyang' (April-June 1978) "Liberal Modes of Capitalist Development in Africa: Ivory Coast," Africa Development (London), 3 (2): 69-87

Onimode, B.. The IMF, World Bank and the African Debt, London: Zed Books, 1989 
Pabanel, Jean-Pierre. Les Coups d'Etat Militaires en Afrique Noire, Paris: L'Harmattan, 1984

Payne, Richard. J. and Jamal R.Nassar. Politics and Culture in the Developing World: The Impact of Globalization, New York and San Francisco: Pearson/Longman, 2008

Pedler, Frederick. Main Currents of West African History, London: The Macmillan Press, 1979

Perrot, Claude-Helène (1er Trimestre 2000). “Chose Vues en Côte D'Ivoire: 15 Au 22 Décembre 1999, " Afrique Contemporaine, No.193, pp. 24-26

Perrot, Claude-Helène. "Laurent Gbagbo: Portrait d'Un Opposant Historique," Afrique Contemporaine, No.196, 4e Trimestre 2000

Perry, Joseph B. and Meredith David P. Collective Bahavior: Response to Social Stress, St. Paul: West Publishing Company, 1978

Potholm, Christian P. Four African Political Systems, Englewood Cliffs (NJ): Prentice Hall, 1970

Pottier, Johan. Re-Imagining Rwanda: Conflict, Survival and Disinformation in the Late Twentieth Century, Cambridge (UK): Cambridge University Press, 2002

Press, Robert M. The New Africa: Dispatches from A Changing Continent, Gainsville: University Press of Florida, 1999

Prosner, Daniel (2004). "Measuring Ethnic Fractionalization in Africa," American Political Science Review 48 (4): 849-863

R.D.A. "Le Rassemblement Démocratique Africain Dans La Lutte Anti-Impérialiste: Brochures Editées Par Le R.D.A., Octobre 1948." in Jacque Baulin, La Politique Intérieure d'Houphouët-Boigny, 34. Paris: Eurafor-Press, 1982

Rake, Alan (December 2000) "The Rise and Rise of Laurent Gbagbo," New African, p. 43

Rapley, J. Ivoirien Capitalism, Boulder and London: Lynne Rienner, 1993

Rawlinson, Alexis. "The Political Manipulation of Ethnicity in Africa”, January 2003. http://www.info@insolens.org

Raynal-Querol, Marta (2002). "Ethnicity, Political Systems, and Civil Wars", Journal of Conflict Resolution 46 (1): 29-54 
Reilly, Benjamin (2002). "Electoral Systems for Divided Societies," Journal of Democracy, 13 (2): 156-179

République de Côte d'Ivoire : La Constitution Ivoirienne Adoptée au Référendum du 2324 July 2000

Robben, Antonius C. G. M., Suarez-Orozco, and Marcelo M. Cultures Under Siege: Collective Violence and Trauma, Cambridge (UK); New York: Cambridge University Press, 2000

Roberts, Stephen. History of French Colonial Policy, Melbourne: University of Melbourne, 1928

Rogan, Patrick M. Civil Wars and Foreign Powers: Outside Intervention in Intrastate Conflict, Ann Arbor: University of Michigan Press, 2000

Ross, Michael L (2004). "What Do We Know About Natural Resources and Civil War?" Journal of Peace Research, 41 (3): 337-356

Ross, Michael L. (2004a). "How Does Natural Resource Wealth Influence Civil War? Evidence from 13 Cases," International Organizations 58 (1): 35-67

Rotberg, Robert et al. Peacekeeping and Peace Enforcement in Africa: Methods of Conflict Prevention, Cambridge (MA): World Peace Foundation and Washington D.C.: Brookings Institutions Press, 2000

Rothchild, Donald (1995) "Ethnic Bargaining and State Breakdown in Africa" Nationalism and Ethnic Politics 1 (1): 54-72

Roubeau, Francois. "La Crise Vue d'En Bas à abidjan: Ethnicité, Governance et Democratie," Afrique Contemporaine, Eté 2003, pp. 57-85

Rupesinghe, Kumar. Civil Wars, Civil Peace: An Introduction to Conflict Resolution. London: Sterling (VA): Pluto Press, 1998

Rupesinghe, Kumar. Internal Conflict and Governance, New York: St. Martin's Press in Association With the International Peace Research Institute, Oslo, 1992

Rupesinghe, Kumar. Conflict Transformation, Hampshire: Macmillan; New York (NY): St Martin's Press, 1995

Russell, Peter H (1995). “Constitution, Citizenship and Ethnicity,” Nationalism and Ethnic Politics, 1 (3): 96-106 
Safran, William (1995). "Nations, Ethnic Groups, States, and Politics. A Preface and An Agenda," Nationalism and Ethnic Politics, 1 (1): 1-10

Safran, William (1998). "Introduction: Nation, Ethnie, Region, and Religion As Markers of Identity," Nationalism and Ethnic Politics 4 (1 \& 2): 1-8.

Saganami, Hidemi (Spring 1990) "Bringing Order to the Causes of War Debate," Millennium, Vol.19, Issue 1, pp. 19-35

Salomone, Franck A. (1976). "Ethnicity and the Nigerian Civil War," Afrique et L'Asie Modernes (France), 4 (111): 5-12

Sambanis, Nicholas (2000). "Partition as a Solution to Civil War," World Politics, 52 (40): 437-483

Sambanis, Nicholas (June 2001). "Do Ethnic and Non-Ethnic Civil Wars Have the Same Causes?: A Theoretical and Empirical Inquiry," Journal of Conflict Resolution, 45 (3): 259-282

Sandler, Todd (December 2000). "Economic Analysis of Conflict," Journal of Conflict Resolution, 44 (6): 723-729

Shafer, Jessica (April 2001). "Guerrillas and Violence in the War in Mozambique: DeSocialization and Re-Socialization?” African Affairs, 100 (399): 215-237

Schatz, P. Sayre (1994). "Structural Adjustment in Africa: A Failing Grade So Far," The Journal of Modern African Studies, 32 (4): 679-692

Schatz, Sayre (June 1996). "The World Bank's Fundamental Misconception in Africa," The Journal of Modern African Studies, 34 (2): 239-247

Schlichte, Klaus (1994). “Is Ethnicity A Cause of War?," Peace Review 6 (1): 59-65

Semi-Bi. Zan (October-November 1986) 'Genèse de la Démocratie à L’'Ivoirienne,' Le Mois en Afrique (Paris), 249 (50): 15-31

Sery, Antoine. Côte d'Ivoire: Après La Faillite, L'Espoir, Paris: L'Harmattan, 1990, $200 \mathrm{p}$

Shaw, Timothy M. (December 2000). "Civil Wars in Africa: Roots and Resolution," Contemporary Security Policy, 21 (3): 200-202

Shaw, Timothy M.And Olajide Aluko. The Political Economy of African Foreign Policy, New York: St. Martin's Press, 1984 
Siddiqui, Rukhsana A.. Sub-Saharan Africa: A Sub-Continent in Transition, Vermont: Avebury, 1993

Sidell, Scott R. The IMF and Third World Political Instability: Is There A Connection? New York: St. Martin Press, 1988

Sirex, Paul-Henri. Houphouët-BoignyOu la Sagesse Africaine, Abidjan and Paris: Nathan, NEA, 1986

Sirex, Paul-Henrin. Houphouët-Boigny, L'homme de la Paix, Seghers: NEA, 1975

Sisk, Timothy. Power Sharing and International Mediation in Ethnic Conflicts, Washington DC: USIP, 1996

Smelser, Neil J. Theory of Collective Behavior, New York: Free Press, 1971

Snyder, Jack. From Voting to Violence: Democratization and Nationalist Conflict, New York: Norton, 1999

Sommerville, Keith (1993). "The Failure of Democratic Reform in Angola and Zaire," Survival (Great Britain), 35 (1): 51-77

Soudan, Francois “Petites Chroniques d'Un Grand Divorce”, in L'Intelligent.com, 10 Juillet 2005

Soudan, Francois. "Côte d'Ivoire: Le Choix de Gbagbo," in Jeune Afrique L'Intelligent, 9 Febraury 2003

Spiegel, L. Steven et al. World Politics in a New Era ( $4^{\text {th }}$ ed), Oxford and New York: Oxford University Press, 2009

Strauss, Scott (April 2001). "The Perils of Ethnicity," African Studies Review, 44 (1): 113-118

Suret-Canale, Jean. French Colonialism in Tropical Africa 1900-1945, New York: Pica Press, 1971

Tapinos, G. Ph. Hugon et P.Vidmard (dir). La Côte d'Ivoire à L'Aube du XXIe Siecle, Paris: Karthala, 2002

Teya, Pascal Koffi. Côte d'Ivoire: Le Roi Est Nu, Paris: L'Harmattan, 1985

The Economist Intelligence Unit "Côte d'Ivoire," August 2002

The Economist Intelligence Unit " Côte d'Ivoire," July 2002 
The Economist Intelligence Unit "Côte d'Ivoire," November 2002

The Military Balance, 1987-1988, London: International Institute for Strategic Studies

Thompson, Virginia and Richard Adloff. French West Africa, New York: Greenwood Press, 1969

Toualy, Georges and Sery Bailly. Réflexion Sur la Crise Ivoirienne, Vivre En Paix Dans Un Etat-Nation Souverain, L'Harmatan, Etudes Africaines, 2005

Toungara, Jeanne Maddox (Fall 1986). "Political Reform and Economic Change in Ivory Coast: An Update," Journal of African Studies (London), 13 (3): 94-101.

Toungara, Jeanne Maddox (1999). "The Apotheosis of Côte d'Ivoire's Nana HouphouêtBoigny," The Journal of Modern African Studies, 28 (1): 23-54

Toungara, Maddox Jeanne (2001) "Ethnicity and Political Crisis in Côte d'Ivoire," Journal of Democracy, 212 (3): 63-72

Touré, Moriba (2000). "Immigration en Côte d'Ivoire: La Notion de "Seuil Tolérable" Relève de la Xénophobie," Politique Africaine, No.78, pp. 75-93

Touré, Abdou. La Civilisation Quotidienne en Côte d' Ivoire, Paris: Editions Karthala, 1981

United Nations Educational, Scientific, and Cultural Organization, International Yearbook of Education, 32, New York, 1980

United Nations Department of International Economic and Social Affairs Statistical Office. Statistical Yearbook, 1983-84, (34 ${ }^{\text {th }}$ Issue), New York, 1986

United Nations Food and Agriculture Organization. FAO Production Yearbook, 1987 and 1988

Van Cott, Donna Lee (1996). "Unity through Diversity: Ethnic Politics and Democracy in Colombia," Nationalism and Ethnic Politics 2 (4): 523-549

Van de Walle, Nicholas. African Economies and the Politics of Permanents Crisis, 19791999, Cambridge: Cambridge University Press, 2001

Van de Walle, Nicholas (2003). "Presidentialism and Clientelism in Africa's Emerging Party Systems, Journal of Modern African Studies, 41 (2): 297-321

Vasquez, John A.(1995). "Why Do Neighbors Fight: Proximity, Interaction, or Territoriality," Journal of Peace Research, 32 (3): 277-293 
Vickers, Michael (1970) "Competitions and Control in Modern Nigeria: Origins of the War with Biafra,” International Journal (Canada), 25 (3): 603-633

Vidal, Claudine (2003). 'La Brutalisation Du Champ Politique Ivoirien, 1990-2003' Revue Africaine de Sociology, 7, 2

Viotti, Paul R. and Mark V. Kauppi $\left(4^{\text {th }}\right)$ International Relations and World Politics: Security, Economy, Identity, Upper Saddle River (NJ): Pearson/Prentice Hall, 2007

Walter, Barbara F. and Snyder, Jack. Civil Wars, Insecurity, and Intervention, New York: Columbia University Press, 1999

Wauthier, Claude. Côte d'Ivoire: A Strange Inheritance, in Le Monde Diplomatique, September 1997

Weekes, Richard V.. Muslim Peoples: A World Ethnographic Survey, Westport (CT): Greenwood Press, 1978

Weiskel, Timothy (1988). "Mission Civilisatrice," The Wilson Quarterly, 12 (4): 97-113

Weiskel, Timothy (1988). "Independence and the Longue Durée: The Ivory Coast "Miracle" Reconsidered" in Prosser Gifford and William Rogers Louis. Decolonization and African Independence, New Haven: Yale University Press, pp. 347-380

Welch, Claude E., Jr. (1987) "Côte d' Ivoire: Personal Rule and Civilian Control," in Claude E. Welch, Jr. (ed.), No Farewell to Arms? Military Disengagement from Politics in Africa and Latin America, Boulder (CO): Westview Press, pp.172-194

Welsh, Paul (15 January 2003) "Ivory Coast: Who Are the Rebels?" BBC News-Africa, 15 January, 2003. http://news.bbc.co.uk/2/hi/africa/2662655.stm

West Africa No.4259, 22-28 February 2001. "Côte d'Ivoire: President Attacks Ouattara"

West Africa Exodus from Côte d'Ivoire," No.4261, 5-11, February 2001

White, Howard (June 1997) "Adjustment and Poverty: Options and Choices," The Journal of Modern African Studies, 35 (2): 335-337

Williams, Robin Murphy. The Wars Within: Peoples and States in Conflict, Ithaca: Cornell University Press, 2003

Woods, Dwayne (2003). "The Tragedy of the Cocoa Pod: Rent-Seeking, Land and Ethnic Conflict in Ivory Coast." Journal of Modern African Studies, 41(4): 641-655

World Armaments and Disarmament: Stockholm International Peace Research Institute Yearbook, Oxford: Oxford University Press, 1986 
World Bank. Ivory Coast: The Challenge of Success, Baltimore: The Johns Hopkins University Press, 1978

World Bank Accelerated Development in Sub-Saharan Africa: An Agenda for Action, Washington D.C.: World Bank, 1981

World Bank. World Debt Tables, 1988

World Bank (1993-2002), World Development Indicators 1993-2002

Woronoff, Jon. West African Wager: Houphouet versus Nkrumah, Metuchen (NJ):

Scarecrow Press, 1972

Wright, Sam. Crowds and Riots: A Study of Social Organization, Beverly Hills (California): Sage Publications, 1978

Young, Crawford. Ideology and Development in Africa, New Haven (Connecticut): Yale University Press, 1982

Zartman, I. William. International Relations in the New Africa, Englewood Cliffs (New Jersey): Prentice-Hall, 1996

Zeleza, Paul Rethinking Africa's Globalization,Vol 1: The Intellectual Challenge, Trenton (NJ): African World Press, Inc, 2003

Zolberg, Aristide R. One-Party Government in the Ivory Coast. Princeton: Princeton University Press, 1964 and 1969

Zoro, Epiphane "La Crise Ivoirienne: Origines, Acteurs, Perspectives. http://www.Abidjan.net (Mars 2003) 
Appendix A

\section{Côte D'Ivoire's Major Languages}

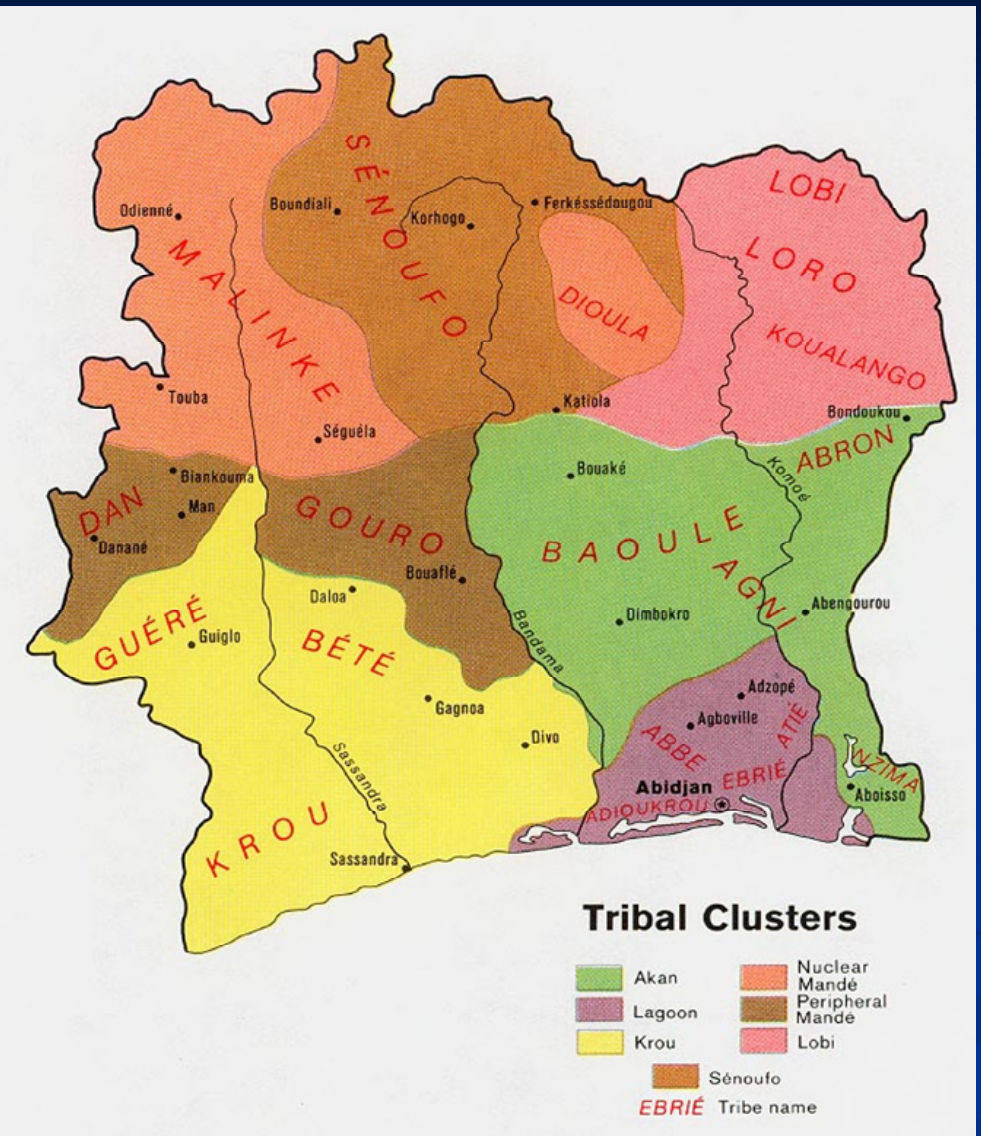


Appendix B

\section{Map of Côte D'Ivoire by Military}

\section{Occupation}

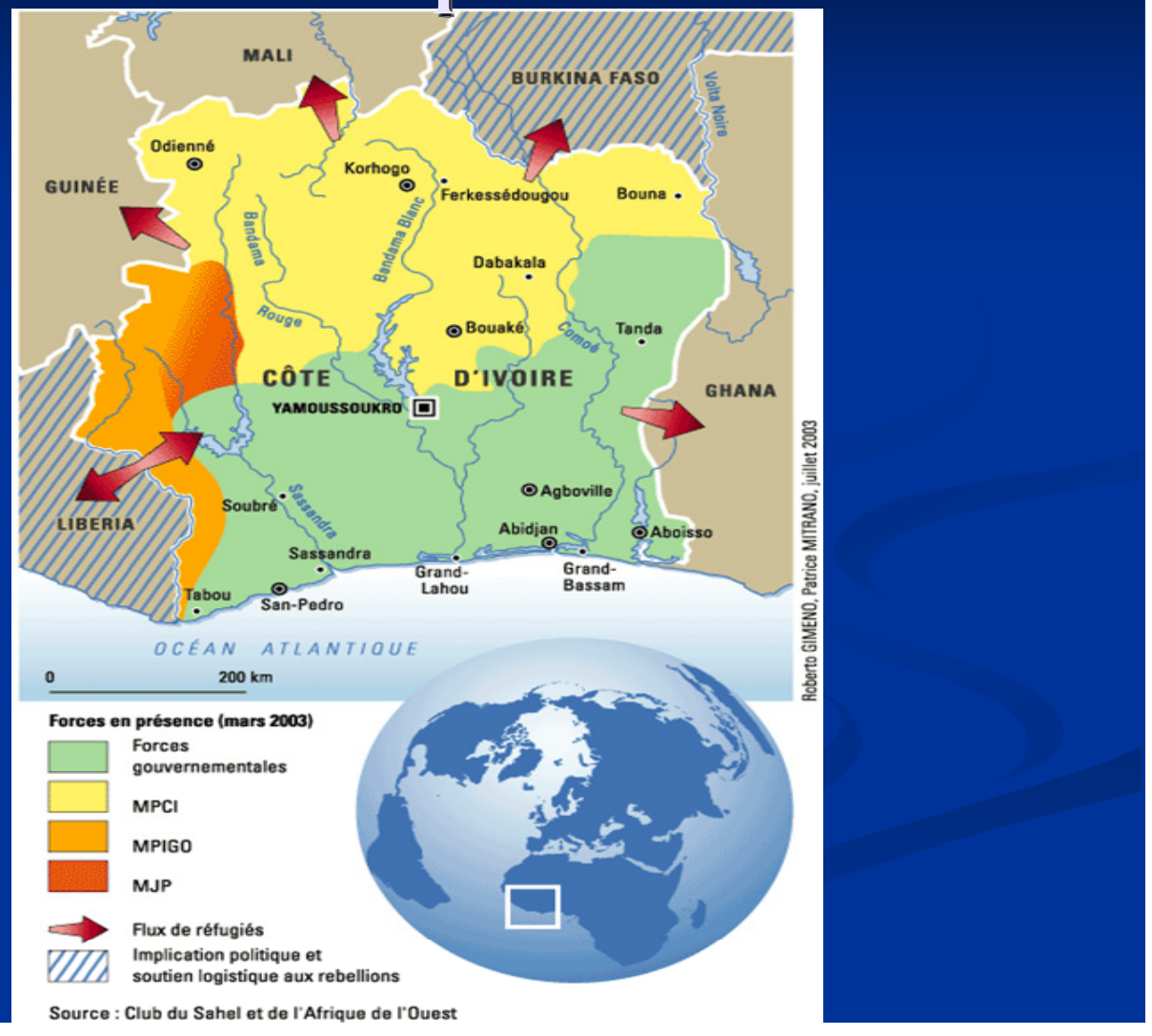


Appendix C

\section{Leaders From 1960 - Present}

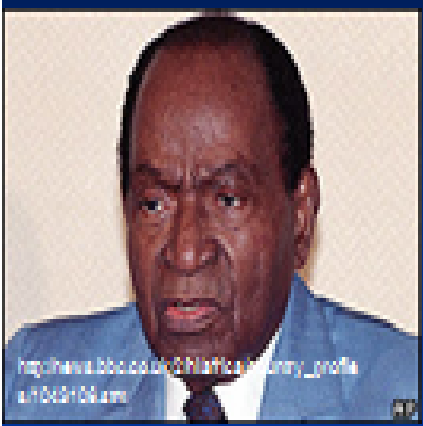

Houplout-Boigny 1960-1995

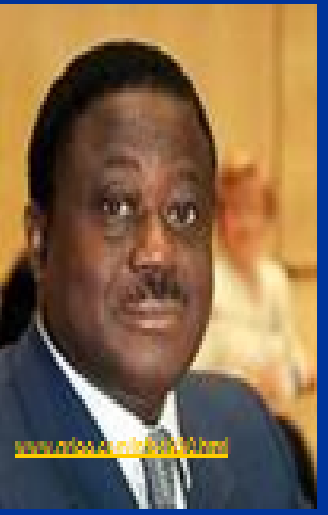

Konan Bedie 1993-1999

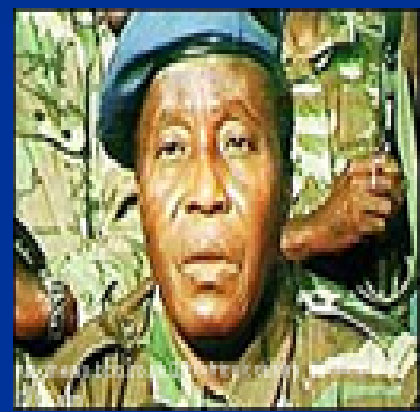

Robert Guei

1999-2000

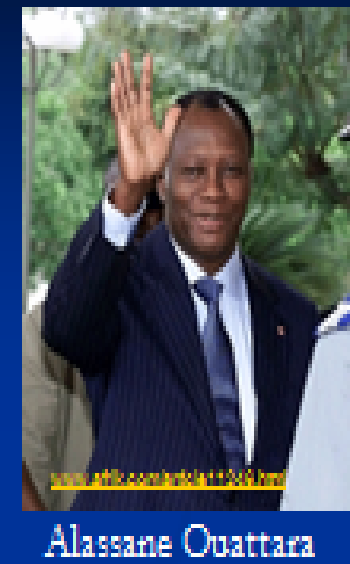

1990-1993

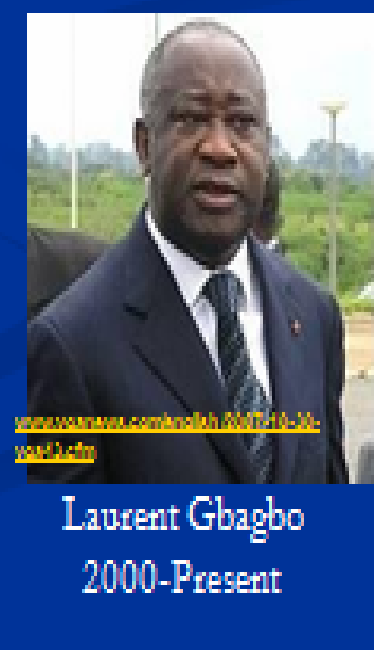

Website Sources on Pictures 
VITA

\section{BERTIN K. KOUADIO}

1998

B.A., Political Science

University of Illinois

Urbana-Champaign, Illinois

2001

M.A., African Studies

University of Illinois

Urbana-Champaign, Illinois

2008-2009

Assistant Professor of International Studies

Wilson College

Chambersburg, Pennsylvania

2009

Doctoral Candidate in International Relations

Florida International University

Miami, Florida

\section{PUBLICATIONS}

Kouadio, K. Bertin (2009). Côte d'Ivoire: Revisiting the Past, Forecasting the Future, Part II in African Affairs. http://www.zeleza.com

Kouadio, K. Bertin (2009). Côte d'Ivoire: Revisiting the Past, Forecasting the Future, Part I in African Affairs. http://www.zeleza.com

Kouadio, K. Bertin (2008). Democratic Experiment in Africa: How Did Côte d'Ivoire Become Victim of the Civil War? The Foundation for Democracy in Africa.

http://www.Foundation-Africa.org

Kouadio, K, Bertin (2007). Côte d'Tvoire: Societies and Cultures. New Encyclopedia of Africa, by James Middleton, Scribner' Sons Book.

Kouadio, K, Bertin (2003). Namibia," Encyclopedia of Twentieth Century African History" by Paul T. Zeleza and Dickson Eyoh (eds.), Routledge.

Kouadio, K, Bertin (2003). Niger, Encyclopedia of Twentieth Century African History" by Paul T. Zeleza and Dickson Eyoh (eds.), Routledge. 